In cooperation with the Houston-Galveston Area Council and the Texas Commission on Environmental Quality

\title{
Hydrologic, Water-Quality, and Biological Data for Three Water Bodies, Texas Gulf Coastal Plain, 2000-2002
}

Open-File Report 03-459

U.S. Department of the Interior U.S. Geological Survey 
U.S. Department of the Interior

U.S. Geological Survey

\section{Hydrologic, Water-Quality, and Biological Data for Three Water Bodies, Texas Gulf Coastal Plain, 2000-2002}

By Jeffery W. East and Jennifer L. Hogan

\section{U.S. GEOLOGICAL SURVEY}

Open-File Report 03-459

In cooperation with the Houston-Galveston Area Council and the Texas Commission on Environmental Quality 


\section{U.S. DEPARTMENT OF THE INTERIOR}

Gale A. Norton, Secretary

\section{U.S. GEOLOGICAL SURVEY}

Charles G. Groat, Director

Any use of trade, product, or firm names is for descriptive purposes only and does not imply endorsement by the U.S. Government.

For additional information write to

\section{District Chief}

U.S. Geological Survey

8027 Exchange Dr.

Austin, TX 78754-4733

E-mail: dc_tx@usgs.gov

Copies of this report can be purchased from

U.S. Geological Survey

Information Services

Box 25286

Denver, CO 80225-0286

E-mail: infoservices@usgs.gov 


\section{CONTENTS}

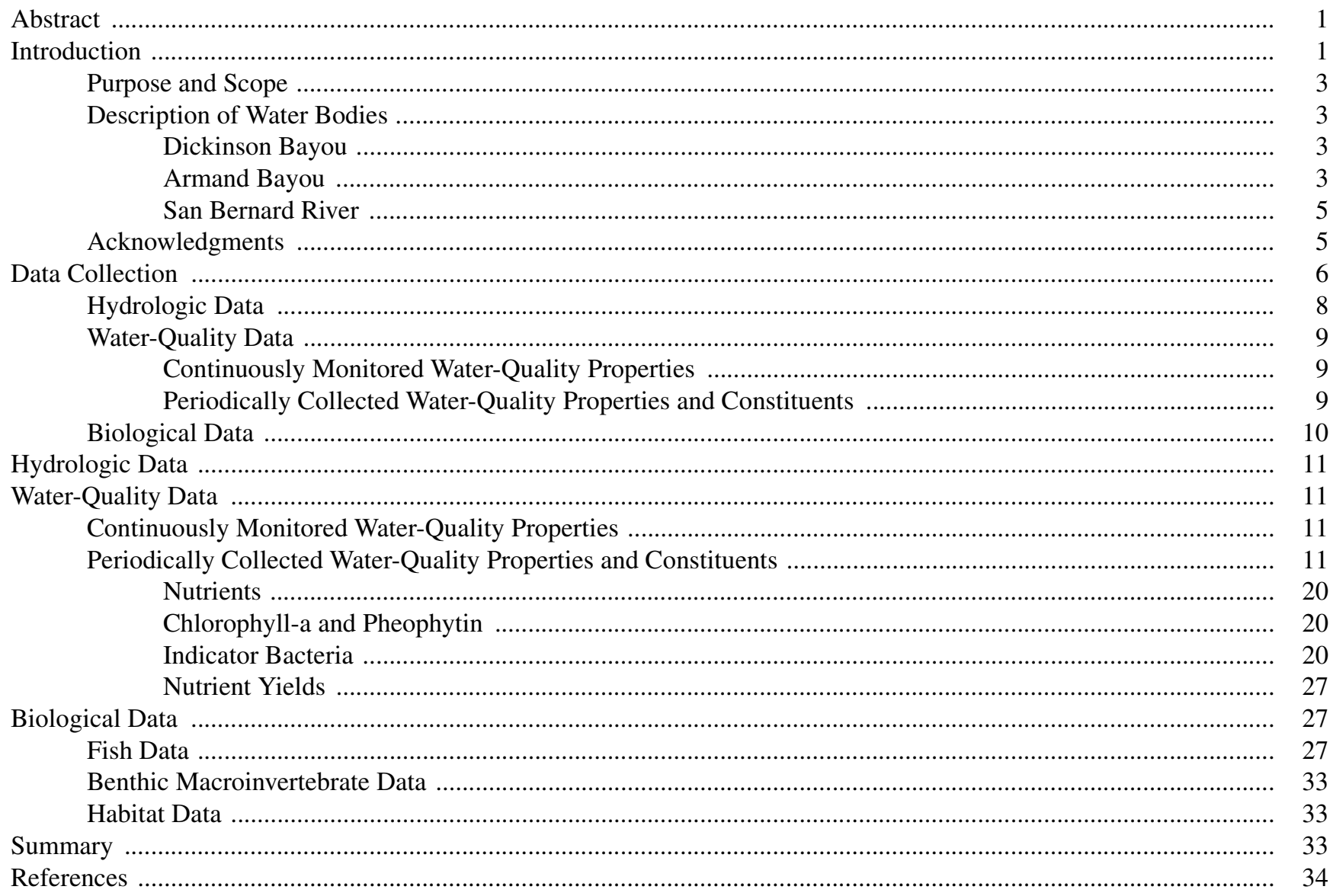

\section{FIGURES}

1-3. Maps showing location of:

1. Dickinson Bayou, Armand Bayou, and San Bernard River, Texas Gulf Coastal Plain, and rain gages

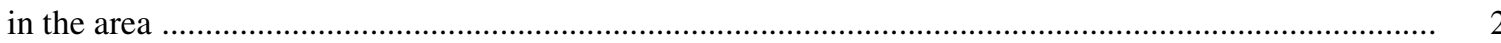

2. Sampling stations in Dickinson and Armand Bayous, Texas Gulf Coastal Plain, 2000-2002 ................ 4

3. Sampling stations in San Bernard River and three tributaries, Texas Gulf Coastal Plain, 2000-2002 ..... 6

4. Graphs showing rainfall at (a) National Weather Service station, League City, Texas, and (b) National Atmospheric Deposition Program station, Attwater Prairie Chicken National Wildlife Refuge near Sealy, Texas, July 2000-September 2002

5. Hydrographs showing daily mean gage height and time of water-quality sampling at (a) station 08077647

Dickinson Bayou at State Highway 3, Dickinson, Texas, and (b) station 293546095052701 Armand

Bayou at Bay Area Boulevard, Pasadena, Texas, July 2000-September 2001

6. Hydrographs showing daily mean discharge and time of water-quality sampling at station $08117500 \mathrm{San}$

Bernard River near Boling, Texas, July 2000-September 2002

7-25. Boxplots showing:

7. Distribution of continuously recorded (15-minute interval) water temperature in (a) Dickinson Bayou, (b) Armand Bayou, and (c) the San Bernard River, Texas Gulf Coastal Plain, November 2000-August 2001

(1)

6

Distribution of continuously recorded (15-minute interval) specific conductance in (a) Dickinson Bayou, (b) Armand Bayou, and (c) the San Bernard River, Texas Gulf Coastal Plain, November 2000-August 2001 
9. Distribution of continuously recorded (15-minute interval) $\mathrm{pH}$ in (a) Dickinson Bayou, (b) Armand Bayou, and (c) the San Bernard River, Texas Gulf Coastal Plain, November 2000-August 2001

10. Distribution of continuously recorded (15-minute interval) dissolved oxygen in (a) Dickinson Bayou, (b) Armand Bayou, and (c) the San Bernard River, Texas Gulf Coastal Plain, November 2000-August 2001

11. Distribution of continuously recorded (15-minute interval) (a) water temperature, (b) specific conductance, (c) pH, and (d) dissolved oxygen at three depths in Dickinson Bayou, Texas Gulf Coastal Plain, December 2000-August 2001

12. Distribution of periodically collected (a) ammonia nitrogen, (b) ammonia plus organic nitrogen, (c) nitrite plus nitrate nitrogen, and (d) orthophosphorus concentrations in Dickinson Bayou, Armand Bayou, and the San Bernard River, Texas Gulf Coastal Plain, 2000-2002

13. Distribution of periodically collected (a) ammonia nitrogen, (b) ammonia plus organic nitrogen, (c) nitrite plus nitrate nitrogen, and (d) orthophosphorus concentrations during high- and low-flow conditions in Dickinson Bayou, Armand Bayou, and the San Bernard River, Texas Gulf Coastal Plain, 2000-2002

14. Seasonal distribution of periodically collected (a) ammonia nitrogen, (b) ammonia plus organic nitrogen, (c) nitrite plus nitrate nitrogen, and (d) orthophosphorus concentrations in Dickinson Bayou, Armand Bayou, and the San Bernard River, Texas Gulf Coastal Plain, 2000-2002

15. Distribution of periodically collected (a) chlorophyll-a and (b) pheophytin concentrations in Dickinson Bayou, Armand Bayou, and the San Bernard River, Texas Gulf Coastal Plain, 20002002

16. Distribution of periodically collected (a) chlorophyll-a and (b) pheophytin concentrations during high- and low-flow conditions in Dickinson Bayou, Armand Bayou, and the San Bernard River, Texas Gulf Coastal Plain, 2000-2002

17. Seasonal distribution of periodically collected (a) chlorophyll-a and (b) pheophytin concentrations in Dickinson Bayou, Armand Bayou, and the San Bernard River, Texas Gulf Coastal Plain, 2000_ 2002

18. Distribution of periodically collected (a) fecal coliform bacteria and (b) E. coli bacteria densities in Dickinson Bayou, Armand Bayou, and the San Bernard River, Texas Gulf Coastal Plain, 20002002

19. Distribution of periodically collected (a) fecal coliform bacteria and (b) E. coli bacteria densities during high- and low-flow conditions in Dickinson Bayou, Armand Bayou, and the San Bernard River, Texas Gulf Coastal Plain, 2000-2002

20. Seasonal distribution of periodically collected (a) fecal coliform bacteria and (b) E. coli bacteria densities in Dickinson Bayou, Armand Bayou, and the San Bernard River, Texas Gulf Coastal Plain, 2000-2002

21. Yields of periodically collected ammonia nitrogen for selected sites in (a) Dickinson Bayou, (b) Armand Bayou, and (c) the San Bernard River, Texas Gulf Coastal Plain, July 1999-September 2001

22. Yields of periodically collected ammonia plus organic nitrogen for selected sites in (a) Dickinson Bayou, (b) Armand Bayou, and (c) the San Bernard River, Texas Gulf Coastal Plain, July 1999_ September 2001

23. Yields of periodically collected nitrite plus nitrate nitrogen for selected sites in (a) Dickinson Bayou, (b) Armand Bayou, and (c) the San Bernard River, Texas Gulf Coastal Plain, July 1999_ September 2001

24. Yields of periodically collected orthophosphorus for selected sites in (a) Dickinson Bayou, (b) Armand Bayou, and (c) the San Bernard River, Texas Gulf Coastal Plain, July 1999-September 2001

25. Yields of periodically collected (a) ammonia nitrogen, (b) ammonia plus organic nitrogen, (c) nitrite plus nitrate nitrogen, and (d) orthophosphorus during high-flow (above base flow) and low-flow (base flow) conditions in Dickinson Bayou, Armand Bayou, and the San Bernard River, Texas Gulf Coastal Plain, 2000-2002 


\section{TABLES}

1. Data-collection sites in Dickinson Bayou, Armand Bayou, and San Bernard River, Texas Gulf Coastal Plain, 2000-2002

2. Laboratories responsible for analyses of samples collected from Dickinson Bayou, Armand Bayou, and San Bernard River, Texas Gulf Coastal Plain, 2000-2002

3. Biological sampling frequency in Dickinson Bayou, Armand Bayou, and San Bernard River, Texas Gulf Coastal Plain

4. Periodically collected water-quality properties and constituents at six sites in Dickinson Bayou, July 2000-August 2001

5. Periodically collected water-quality properties and constituents at four sites in Armand Bayou, August 2000-July 2001

6. Periodically collected water-quality properties and constituents at six sites in the San Bernard River, January 2001-August 2002

7. Screening levels for selected nutrients

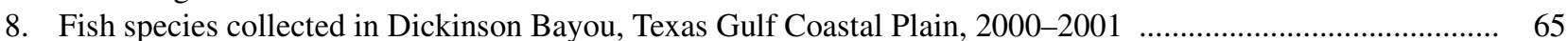

9. Fish species collected in Armand Bayou, Texas Gulf Coastal Plain, 2000-2001 .....

10. Fish taxa and counts of individual fish collected in the San Bernard River, Texas Gulf Coastal Plain, 2000-2002

11. Fish community data (metrics) for sites in Dickinson Bayou, Armand Bayou, and the San Bernard River, Texas Gulf Coastal Plain, 2000-2002

12. Benthic macroinvertebrate taxa and counts of individual taxa collected in the San Bernard River, Texas Gulf Coastal Plain, 2000-2002

13. Benthic macroinvertebrate data (metrics) for sites in Dickinson Bayou, Armand Bayou, and the San Bernard River, Texas Gulf Coastal Plain, 2000-2001

14. Physical-habitat data for stream reaches at sites in the San Bernard River, Texas Gulf Coastal Plain, 2000-2001

\section{VERTICAL DATUM}

Vertical coordinate information is referenced to the National Geodetic Vertical Datum of 1929 (NGVD 29). 


\title{
Hydrologic, Water-Quality, and Biological Data for Three Water Bodies, Texas Gulf Coastal Plain, 2000-2002
}

\author{
By Jeffery W. East and Jennifer L. Hogan
}

\section{Abstract}

During July 2000-September 2002, the U.S. Geological Survey collected and analyzed site-specific hydrologic, water-quality, and biological data in Dickinson Bayou, Armand Bayou, and the San Bernard River in the Gulf Coastal Plain of Texas. Segments of the three water bodies are on the State 303(d) list. Continuous monitoring showed that seasonal variations in water temperature, specific conductance, $\mathrm{pH}$, and dissolved oxygen in all three water bodies were similar to those observed at U.S. Geological Survey stations along the Texas Gulf Coast. In particular, water temperature and dissolved oxygen are inversely related. Periods of smallest dissolved oxygen concentrations generally occurred in the summer months when water temperatures were highest. Waterquality monitors were deployed at three depths in Dickinson Bayou. For periodically collected nutrients, the median concentration of ammonia nitrogen was largest in Dickinson Bayou and smallest in the San Bernard River. Median concentrations of ammonia plus organic nitrogen, nitrite plus nitrate nitrogen, and orthophosphorus were largest in Armand Bayou. The median concentration of each of the four nutrients was larger for high-flow samples than for low-flow samples. The largest individual nutrient concentrations occurred during spring and summer. Both median and individual concentrations of chlorophyll-a were largest for Armand Bayou; median concentrations of pheophyton were similar for all three water bodies, and individual concentrations were largest for Armand Bayou. Median densities of fecal coliform bacteria and $E$. coli bacteria were similar for all three water bodies. Flow conditions had minimal effect on con- centrations of chlorophyll-a and pheophytin, but the largest bacteria densities were in samples collected during high flow. Yields of most nutrients tended to increase with distance downstream. Yields in the San Bernard River and tributaries were less than yields in Dickinson and Armand Bayous. For Dickinson and Armand Bayous, the most individuals and species of fish were collected at the most downstream main stem site; for the San Bernard River, the fewest individuals and species of fish were collected at the most downstream main stem site.

\section{INTRODUCTION}

From July 2000 through September 2002, the U.S. Geological Survey (USGS) conducted a study in cooperation with the Houston-Galveston Area Council (H-GAC) and the Texas Commission on Environmental Quality (TCEQ) (formerly the Texas Natural Resource Conservation Commission) as a part of the Clean Rivers Program. The study involved collection and analysis of site-specific hydrologic, water-quality, and biological data in three water bodies in the Gulf Coastal Plain of Texas-Dickinson Bayou, Armand Bayou, and the San Bernard River and three of its tributaries (hereinafter referred to as the San Bernard River) (fig. 1).

Such data are of interest because segments of the three water bodies are on the State 303(d) list. Section 303(d) of the Clean Water Act requires states to submit to the U.S. Environmental Protection Agency annual listings of water bodies that are impaired-that is, they do not meet or are not expected to meet applicable TCEQ water-quality standards based on designated uses of the water bodies. The TCEQ uses water-quality data collected by several agencies to determine whether a water body meets the water-quality standards for its designated use. 

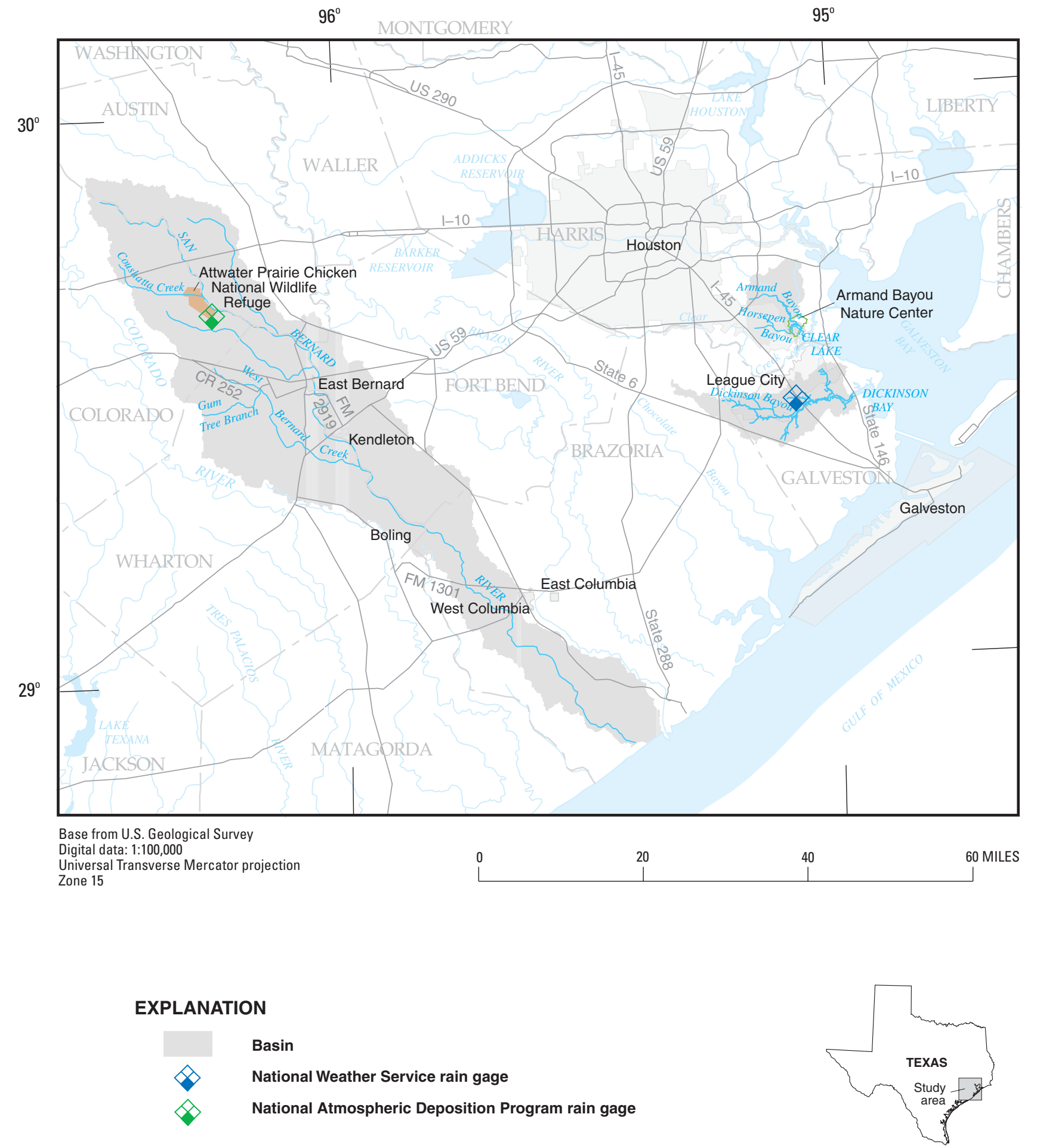

LOCATION MAP

Figure 1. Location of Dickinson Bayou, Armand Bayou, and San Bernard River, Texas Gulf Coastal Plain, and rain gages in the area. 
Section 303(d) further requires states to develop total maximum daily loads (TMDLs) for impaired water bodies. TMDLs set maximum amounts of pollutants that a water body can receive and still meet waterquality standards. Site-specific data thus are needed to define spatial and temporal variations in water-quality properties and constituents and in biological indicators of water quality. These data can contribute to a more complete understanding of water-quality conditions in a given water body and can indicate how appropriate State criteria are for that water body.

\section{Purpose and Scope}

The purpose of this report is to present hydrologic, water-quality, and biological data collected from Dickinson Bayou, Armand Bayou, and the San Bernard River during July 2000-September 2002. Tables and graphs present hydrologic data and water-quality properties that were collected at one site (station) in each of the three study areas at 15-minute intervals. Tables and graphs present water-quality properties and constituents sampled monthly at six sites in Dickinson Bayou, every other month at four sites in Armand Bayou, and every other month at six sites in the San Bernard River. Tables present fish, benthic macroinvertebrate, and stream-habitat data that were collected in or computed for each of the three water bodies. Biological data for Dickinson and Armand Bayous presented previously in Hogan (2002) is referred to but not repeated in this report.

\section{Description of Water Bodies}

\section{Dickinson Bayou}

Dickinson Bayou is about 25 miles (mi) southeast of Houston (fig. 2). The bayou is about 24 river miles long and is within Galveston County, although the westernmost part of the 106-square-mile $\left(\mathrm{mi}^{2}\right)$ drainage area (watershed) is in Brazoria County. All or parts of the cities of Dickinson, Alvin, Friendswood, Santa Fe, League City, and Texas City are in the watershed.

Dickinson Bayou flows eastward toward Dickinson Bay, a secondary bay of the Galveston Bay system. Dickinson Bayou is part of the San Jacinto-Brazos Coastal Basin and comprises two stream segments as defined by TCEQ. Stream segment 1104 is the Dickinson Bayou above-tidal reach, which flows $7.3 \mathrm{mi}$ from Farm Road 528 to 1.2 mi downstream of Farm Road 517. Segment 1103 is the Dickinson Bayou tidal reach, which starts 1.2 mi downstream of Farm Road 517 and flows 16.4 mi to the Dickinson Bayou confluence with Dickinson Bay. Flow regimes in the two reaches are markedly different. The above-tidal reach is a relatively shallow stream (about 1 to 3 feet [ft] deep) with moving water, whereas the tidal reach is a predominantly deep channel (about 5 to $20 \mathrm{ft}$ deep) with very sluggish flow. Streamside vegetation also is different. The above-tidal reach is characterized by dense, riparian vegetation that limits sunlight exposure, whereas vegetation in the tidal reach is less dense, which allows more exposure to sunlight. The topography of the watershed slopes gently toward the bayou. Land-surface altitude varies from about $50 \mathrm{ft}$ above sea level in the west to sea level at the mouth of the bayou. Soils primarily are clays or loams with low permeability.

Land use varies from farmland and rangeland to concentrated residential and commercial development. The areas with the largest percentage of development are those near Dickinson and League City. About 10 percent of the basin is urban, 15 percent is pasture, and the remaining 75 percent is rural (East and others, 1998). Field inspections during the current study indicate that appreciable urban development near Dickinson has occurred since 1990, so it is likely that the percentage of the basin that is urban is greater than 10 percent.

In 1992, Dickinson Bayou was designated as "water-quality limited" by the Texas Water Commission (1992, p. 391). This designation means that streammonitoring data indicated that surface-water-quality standards are not being met. In 2002, both stream segments were on the State 303(d) list because of elevated bacteria levels; segment 1103 (Dickinson Bayou tidal) also was listed because of small dissolved oxygen concentrations (Texas Commission on Environmental Quality, 2002).

\section{Armand Bayou}

Armand Bayou is about 20 mi southeast of Houston, north of Dickinson Bayou (fig. 2). Armand Bayou is about 14 river miles long and has a drainage area of about $63 \mathrm{mi}^{2}$, which includes the drainage area of Horsepen Bayou, a major tributary to Armand Bayou. The watershed, which is within Harris County, contains parts of the cities of Pasadena and Clear Lake, as well as the National Aeronautics and Space Administration (NASA) Johnson Space Center, Ellington Air Field, and the Bayport petrochemical complex. 


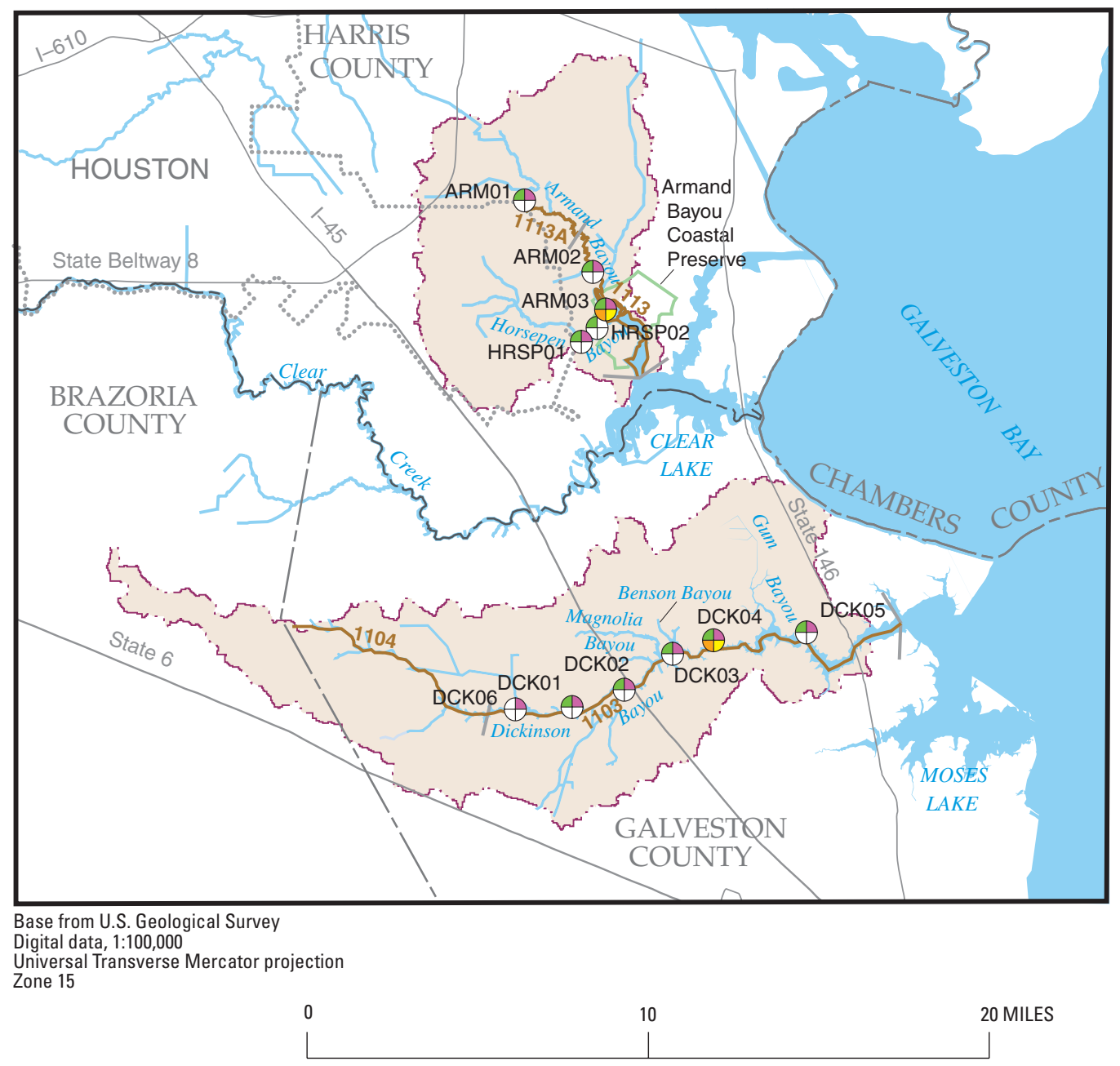

\section{EXPLANATION}

$\begin{array}{ll}1113 & \begin{array}{l}\text { Watershed } \\ 2000 \text { Texas Clean Water Act Section 303(d)-listed } \\ \text { segment and number }\end{array} \\ & \begin{array}{l}\text { Stream segment boundary (Source: Texas Commission } \\ \text { on Environmental Quality) }\end{array} \\ \begin{array}{l}\text { Type of U.S. Geological Survey station and short name- } \\ \text { HRSP02 }\end{array} & \begin{array}{l}\text { Short name referenced in table 1 } \\ \text { BCK05 }\end{array} \\ \begin{array}{c}\text { ARM03 } \\ \oplus\end{array} & \text { Water-quality sampling station } \\ \text { DCK04 } & \text { Continuous-record water-quality monitoring station } \\ \oplus & \text { Continuous-record stage station }\end{array}$

Figure 2. Location of sampling stations in Dickinson and Armand Bayous, Texas Gulf Coastal Plain, 2000-2002. 
Armand Bayou flows southward through Mud Lake, then into Clear Lake (fig. 2). Armand Bayou is part of the San Jacinto-Brazos Coastal Basin and comprises two stream segments as defined by TCEQ. Stream segment 1113-A is the Armand Bayou abovetidal reach, which flows from the headwaters to a point 0.5 mi downstream of Genoa-Red Bluff Road. Segment 1113 is the Armand Bayou tidal reach, which flows from 0.5 mi downstream of Genoa-Red Bluff Road to the confluence with Clear Lake, at the NASA Road 1 bridge crossing. Flow regimes in the two reaches are similar to those in Dickinson Bayou. The above-tidal reach is a relatively shallow stream (about 1 to $2 \mathrm{ft}$ deep) with moving water, whereas the tidal reach is much wider, with deep holes (about 5 to $10 \mathrm{ft}$ ) and very sluggish flow. The topography of the watershed slopes gently toward the bayou. Land-surface altitude varies from about $40 \mathrm{ft}$ above sea level in the north to sea level at the mouth of the bayou. Coplin and Lanning-Rush (2002) show that land-surface subsidence of about $1 \mathrm{ft}$ occurred in the Armand Bayou watershed during 1973-2001. It is likely that additional subsidence occurred prior to 1973, when monitoring equipment was installed. The effects of this physiographic change on the freshwater marsh system of Armand Bayou currently (2003) are unknown. However, it is anticipated that in this low-gradient watershed, land-surface subsidence of this magnitude could alter hydrodynamics (flow patterns, velocity, and so forth). Soils primarily are clays or loams with low permeability. Land use in the watershed has been categorized as residential, commercial, industrial, and undeveloped bottomland hardwood forest and coastal prairie (Parsons Engineering Science, Inc., 2000).

The Armand Bayou watershed is an important nursery and breeding habitat for fish and wildlife of the Galveston Bay estuarine system. The area also supports numerous nesting birds, mammals, reptiles, and amphibians. According to the Texas Parks and Wildlife Department (1997), "The Bayou and its watershed support biota and remnant habitats that were present during a more pristine era. It also functions as a flood control system, riparian habitat, and water quality mitigation area. The Bayou's uniqueness is that of a remnant natural system still existing within a heavily developed, densely populated region." Because of the ecological significance of Armand Bayou, in 1991 the Texas Parks and Wildlife Department established the 2,800-acre Armand Bayou Coastal Preserve.
In 1998, Armand Bayou was listed on the State 303(d) list because of elevated bacteria levels and small dissolved oxygen concentrations (Texas Natural Resource Conservation Commission, 1998). In 2002, additional data showed that the stream met criteria for contact recreation use, so the listing for elevated bacteria was removed. However, the stream was still listed for small dissolved oxygen concentrations (Texas Commission on Environmental Quality, 2002).

\section{San Bernard River}

The San Bernard River, which drains an appreciably larger watershed (more than $900 \mathrm{mi}^{2}$ ) than Dickinson Bayou (106 mi ${ }^{2}$ ) and Armand Bayou (63 $\mathrm{mi}^{2}$ ), is in the Brazos-Colorado Coastal Basin (fig. 3). The river flows southeast, forming the boundary between Austin and Colorado Counties, then into Wharton and Fort Bend Counties, before eventually flowing into the Gulf of Mexico. Total length of the river is about $125 \mathrm{mi}$. The San Bernard River comprises two stream segments as defined by TCEQ. Stream segment 1302 is the San Bernard River above-tidal reach, which flows from the city of New Elm in Austin County to a point $2.0 \mathrm{mi}$ upstream of State Highway 35 in Brazoria County. Stream segment 1301 is San Bernard River tidal reach, which flows from 2.0 mi upstream of State Highway 35 in Brazoria County to the confluence with the Intracoastal Waterway in Brazoria County. Land use in the watershed primarily is rural and agricultural, with scattered areas of urbanization.

In 2002, segment 1302 (San Bernard River above tidal) was on the 303(d) list for not supporting contact recreation use because of elevated bacteria levels, not supporting general use because of elevated water temperature, and concerns that fish and benthic macroinvertebrate communities were impaired in the stream segment (Texas Commission on Environmental Quality, 2002). All designated stream uses for segment 1301 (San Bernard River tidal) were fully supported, thus that segment was not on the 303(d) list.

\section{Acknowledgments}

The authors thank Todd Running, Patrick Horton, and Karen Brettschneider, H-GAC, and Laurie Curra, TCEQ, for providing assistance throughout the study. Jim McLaughlin and Chuck Wemple, formerly of $\mathrm{H}-\mathrm{GAC}$, assisted during the planning and datacollection stages of the study. Also, Jean Wright and Roy Drinnen, Galveston County Health District 


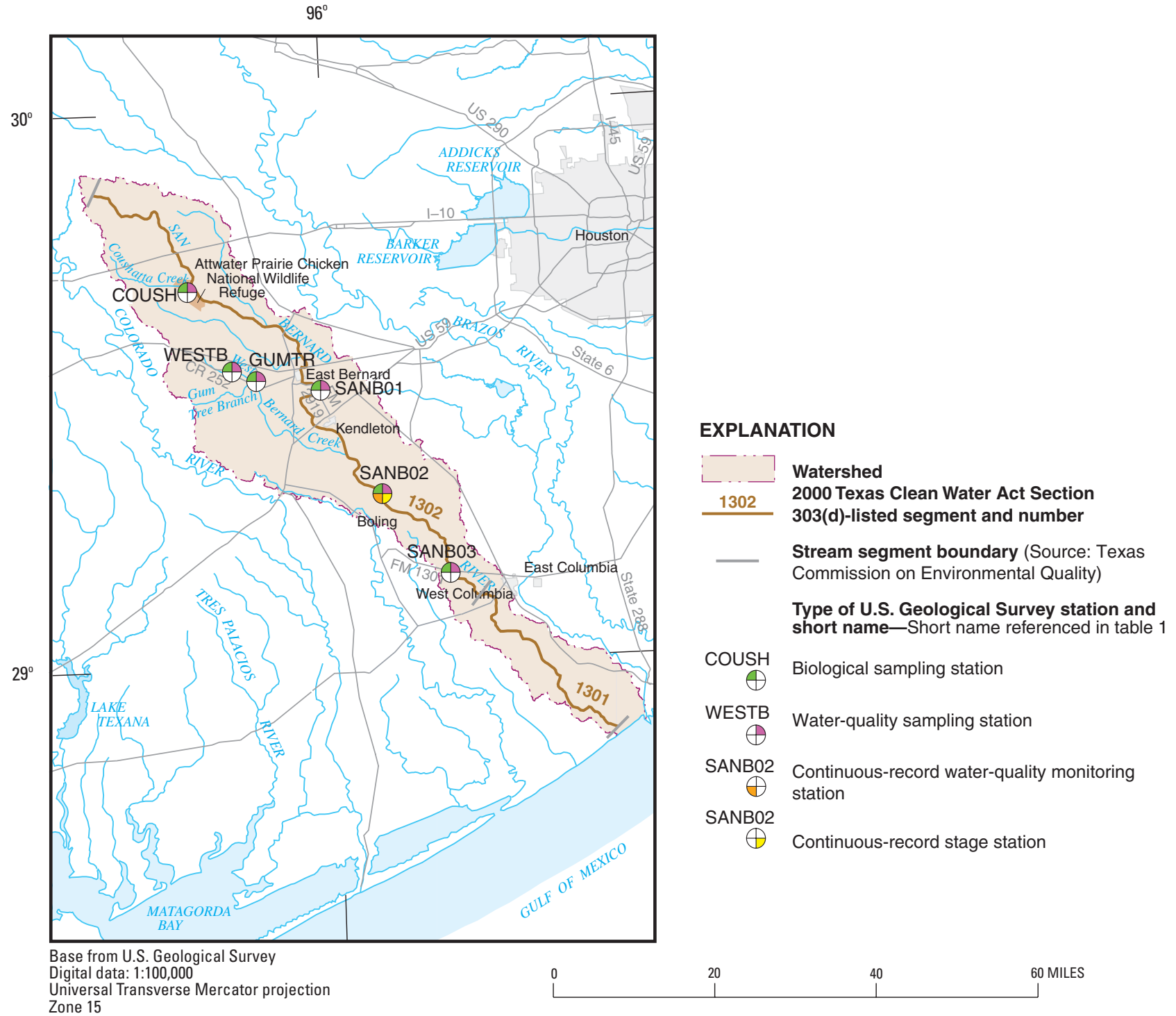

Figure 3. Location of sampling stations in San Bernard River and three tributaries, Texas Gulf Coastal Plain, 2000-2002.

(GCHD), and others from GCHD and TCEQ provided invaluable assistance during field data-collection activities. Staff of the University of Texas Memorial Museum assisted by identifying unknown fish species. Additionally, the authors gratefully acknowledge the City of Pasadena, City of Dickinson, and Texas Department of Transportation for permission to install and operate equipment during the study.

\section{DATA COLLECTION}

A variety of data were collected during the 26-month study period to characterize water-quality and biological conditions in the three water bodies, both spatially and temporally. The data were hydrologic properties (rainfall, stage, and streamflow), continuously monitored water-quality properties (water temperature, specific conductance, $\mathrm{pH}$, and dissolved oxygen), periodically monitored water-quality properties and constituents (nutrients, phytoplankton, indicator bacteria, suspended sediment, and biochemical oxygen demand [BOD]), and biological properties (fish, benthic macroinvertebrates, and stream habitat). The data-collection activities are summarized in table 1 . In addition to environmental samples, quality assurance (QA) samples also were collected during the study. 
Table 1. Data-collection sites in Dickinson Bayou, Armand Bayou, and San Bernard River, Texas Gulf Coastal Plain, 2000-2002

[IH, Interstate Highway; SH, State Highway; CR, County Road; FM, Farm Road]

\begin{tabular}{|c|c|c|c|c|c|c|}
\hline $\begin{array}{l}\text { Station } \\
\text { number }\end{array}$ & $\begin{array}{l}\text { Station } \\
\text { name }\end{array}$ & $\begin{array}{l}\text { Short } \\
\text { name } \\
\text { (fig. } 2 \\
\text { or 3) }\end{array}$ & $\frac{\text { Location }}{\text { Latitude Longitude }}$ & $\begin{array}{l}\text { Drainage } \\
\text { area } \\
\text { (square } \\
\text { miles) }\end{array}$ & $\begin{array}{l}\text { Population } \\
\text { density }{ }^{1} \\
\text { (people per } \\
\text { square mile) }\end{array}$ & $\begin{array}{l}\text { Data-collection } \\
\text { activity }\end{array}$ \\
\hline \multicolumn{7}{|c|}{ Dickinson Bayou } \\
\hline 0807764230 & $\begin{array}{l}\text { Dickinson Bayou at } \\
\text { Ginger Rd., near Alvin, } \\
\text { Tex. }\end{array}$ & DCK06 & $29^{\circ} 25^{\prime} 39^{\prime \prime} 95^{\circ} 07^{\prime} 54^{\prime \prime}$ & 31.2 & 291 & Monthly water-quality sampling \\
\hline 08077643 & $\begin{array}{l}\text { Dickinson Bayou at } \\
\text { Cemetary Rd. near } \\
\text { Dickinson, Tex. }\end{array}$ & DCK01 & $29^{\circ} 25^{\prime} 45^{\prime \prime} 95^{\circ} 06^{\prime} 56^{\prime \prime}$ & 43.6 & 296 & $\begin{array}{l}\text { Monthly water-quality sampling } \\
\text { Biological sampling }\end{array}$ \\
\hline 08077645 & $\begin{array}{l}\text { Dickinson Bayou near } \\
\text { IH-45, Dickinson, Tex. }\end{array}$ & DCK02 & $29^{\circ} 26^{\prime} 40^{\prime \prime} 95^{\circ} 04^{\prime} 23^{\prime \prime}$ & 57.3 & 296 & $\begin{array}{l}\text { Monthly water-quality sampling } \\
\text { Biological sampling }\end{array}$ \\
\hline 0807764550 & $\begin{array}{l}\text { Dickinson Bayou up- } \\
\text { stream of Benson } \\
\text { Bayou, Dickinson, } \\
\text { Tex. }\end{array}$ & DCK03 & $29^{\circ} 27^{\prime} 18^{\prime \prime} 95^{\circ} 03^{\prime} 42^{\prime \prime}$ & 67.4 & 337 & $\begin{array}{l}\text { Monthly water-quality sampling } \\
\text { Biological sampling }\end{array}$ \\
\hline 08077647 & $\begin{array}{l}\text { Dickinson Bayou at } \\
\text { SH 3, Dickinson, Tex. }\end{array}$ & DCK04 & $29^{\circ} 27^{\prime} 23^{\prime \prime} 95^{\circ} 02^{\prime} 52^{\prime \prime}$ & 75.0 & 402 & $\begin{array}{l}\text { Continuous stage } \\
\text { Continuous water-quality monitoring } \\
\text { Monthly water-quality sampling } \\
\text { Biological sampling }\end{array}$ \\
\hline 0807764915 & $\begin{array}{l}\text { Dickinson Bayou below } \\
\text { Gum Bayou, near } \\
\text { Texas City, Tex. }\end{array}$ & DCK05 & $29^{\circ} 27^{\prime} 40^{\prime \prime} 94^{\circ} 59^{\prime} 59^{\prime \prime}$ & 93.5 & 502 & $\begin{array}{l}\text { Monthly water-quality sampling } \\
\text { Biological sampling }\end{array}$ \\
\hline \multicolumn{7}{|c|}{ Armand Bayou } \\
\hline 293847095074501 & $\begin{array}{l}\text { Armand Bayou at Fair- } \\
\text { mont Pkwy., Pasadena, } \\
\text { Tex. }\end{array}$ & ARM01 & $29^{\circ} 38^{\prime} 47^{\prime \prime} 95^{\circ} 07^{\prime} 45^{\prime \prime}$ & 7.71 & 3,160 & $\begin{array}{l}\text { Bimonthly water-quality sampling } \\
\text { Biological sampling }\end{array}$ \\
\hline 293645095054601 & $\begin{array}{l}\text { Armand Bayou at Oil } \\
\text { Field Rd., Pasadena, } \\
\text { Tex. }\end{array}$ & ARM02 & $29^{\circ} 36^{\prime} 45^{\prime \prime} 95^{\circ} 05^{\prime} 46^{\prime \prime}$ & 25.4 & 2,190 & $\begin{array}{l}\text { Bimonthly water-quality sampling } \\
\text { Biological sampling }\end{array}$ \\
\hline 293546095052701 & $\begin{array}{l}\text { Armand Bayou at Bay } \\
\text { Area Blvd., Pasadena, } \\
\text { Tex. }\end{array}$ & ARM03 & $29^{\circ} 35^{\prime} 46^{\prime \prime} 95^{\circ} 05^{\prime} 27^{\prime \prime}$ & 35.3 & 1,940 & $\begin{array}{l}\text { Continuous stage } \\
\text { Continuous water-quality monitoring } \\
\text { Bimonthly water-quality sampling } \\
\text { Biological sampling }\end{array}$ \\
\hline 08077630 & $\begin{array}{l}\text { Horsepen Bayou at Bay } \\
\text { Area Blvd., Houston, } \\
\text { Tex. }\end{array}$ & HRSP01 & $29^{\circ} 35^{\prime} 00^{\prime \prime} 95^{\circ} 06^{\prime} 12^{\prime \prime}$ & 16.7 & 2,240 & $\begin{array}{l}\text { Bimonthly water-quality sampling } \\
\text { Biological sampling }\end{array}$ \\
\hline 293444095055101 & $\begin{array}{l}\text { Horsepen Bayou at } \\
\text { Middlebrook Dr., } \\
\text { Pasadena, Tex. }\end{array}$ & HRSP02 & $29^{\circ} 34^{\prime} 44^{\prime \prime} 95^{\circ} 05^{\prime} 51^{\prime \prime}$ & 17.4 & 2,190 & Biological sampling \\
\hline \multicolumn{7}{|c|}{ San Bernard River and tributaries } \\
\hline 294036096165001 & $\begin{array}{l}\text { Coushatta Creek at } \\
\text { Attwater Prairie } \\
\text { Chicken National } \\
\text { Wildlife Refuge, Tex. }\end{array}$ & COUSH & $29^{\circ} 40^{\prime} 36^{\prime \prime} 96^{\circ} 16^{\prime} 50^{\prime \prime}$ & 39.9 & 10 & $\begin{array}{l}\text { Bimonthly water-quality sampling } \\
\text { Biological sampling }\end{array}$ \\
\hline 293211096110301 & $\begin{array}{l}\text { West Bernard Creek at } \\
\text { CR 252, near East } \\
\text { Bernard, Tex. }\end{array}$ & WESTB & $29^{\circ} 32^{\prime} 11^{\prime \prime} 96^{\circ} 11^{\prime} 03^{\prime \prime}$ & 22.1 & 39 & $\begin{array}{l}\text { Bimonthly water-quality sampling } \\
\text { Biological sampling }\end{array}$ \\
\hline
\end{tabular}


Table 1. Data-collection sites in Dickinson Bayou, Armand Bayou, and San Bernard River, Texas Gulf Coastal Plain, 2000-2002-Continued

\begin{tabular}{|c|c|c|c|c|c|c|}
\hline $\begin{array}{l}\text { Station } \\
\text { number }\end{array}$ & $\begin{array}{l}\text { Station } \\
\text { name }\end{array}$ & $\begin{array}{l}\text { Short } \\
\text { name } \\
\text { (fig. } 2 \\
\text { or } 3 \text { ) }\end{array}$ & $\frac{\text { Location }}{\text { Latitude Longitude }}$ & $\begin{array}{l}\text { Drainage } \\
\text { area } \\
\text { (square } \\
\text { miles) }\end{array}$ & $\begin{array}{l}\text { Population } \\
\text { density } 1 \\
\text { (people per } \\
\text { square mile) }\end{array}$ & $\begin{array}{l}\text { Data-collection } \\
\text { activity }\end{array}$ \\
\hline \multicolumn{7}{|c|}{ San Bernard River and tributaries-Continued } \\
\hline 293123096073001 & $\begin{array}{l}\text { Gum Tree Branch at } \\
\text { CR 252, near East } \\
\text { Bernard, Tex. }\end{array}$ & GUMTR & $29^{\circ} 31^{\prime} 23^{\prime \prime} 96^{\circ} 07^{\prime} 30^{\prime \prime}$ & 35.1 & 29 & $\begin{array}{l}\text { Bimonthly water-quality sampling } \\
\text { Biological sampling }\end{array}$ \\
\hline 292939096014001 & $\begin{array}{l}\text { San Bernard River at } \\
\text { FM } 2919 \text { near } \\
\text { Kendleton, Tex. }\end{array}$ & SANB01 & $29^{\circ} 29^{\prime} 39^{\prime \prime} 96^{\circ} 01^{\prime} 40^{\prime \prime}$ & 375 & 24 & $\begin{array}{l}\text { Bimonthly water-quality sampling } \\
\text { Biological sampling }\end{array}$ \\
\hline 08117500 & $\begin{array}{l}\text { San Bernard River near } \\
\text { Boling, Tex. }\end{array}$ & SANB02 & $29^{\circ} 18^{\prime} 48^{\prime \prime} 95^{\circ} 53^{\prime} 37^{\prime \prime}$ & 727 & 30 & $\begin{array}{l}\text { Continuous streamflow } \\
\text { Continuous water-quality monitoring } \\
\text { Bimonthly water-quality sampling } \\
\text { Biological sampling }\end{array}$ \\
\hline 290935095455601 & $\begin{array}{l}\text { San Bernard River at } \\
\text { FM } 1301 \text { near East } \\
\text { Columbia, Tex. }\end{array}$ & SANB03 & $29^{\circ} 09^{\prime} 35^{\prime \prime} 95^{\circ} 45^{\prime} 56^{\prime \prime}$ & 825 & 32 & $\begin{array}{l}\text { Bimonthly water-quality sampling } \\
\text { Biological sampling }\end{array}$ \\
\hline
\end{tabular}

\footnotetext{
${ }^{1}$ See text, page 27.
}

Depending on the constituent type, QA samples consisted of equipment blanks, field blanks, laboratory blanks, split samples, replicate samples, and laboratory matrix spikes.

\section{Hydrologic Data}

All precipitation during the study was rainfall. Rainfall data were obtained from two sources: (1) the National Weather Service (NWS) station at League City (National Weather Service, 2003) (fig. 1) — data from this station are representative of conditions for both Dickinson Bayou and Armand Bayou; and (2) the National Atmospheric Deposition Program (NADP) station at the Attwater Prairie Chicken National Wildlife Refuge near Sealy (National Atmospheric Deposition Program [NRSP-3]/National Trends Network, 2003) (fig. 1) - data from this station were assumed to be representative of the San Bernard study area.

Gage height (stage) was continuously monitored in each of the three water bodies (figs. 2, 3; table 1). Gage height at the Dickinson Bayou and Armand Bayou gages is tidally influenced. Gage height (stage) is defined as the water surface measured in feet above a local reference point, or "gage datum." For the Dickinson Bayou and Armand Bayou gages, the gage datum was arbitrarily chosen and not referenced to a particular datum. Gage height data for the San Bernard River gage were referenced to NGVD 29.

Gage height data were measured using pressure transducers. The data were electronically recorded at 15-minute intervals by data-collection platforms (DCPs) and transmitted by a geostationary operational environmental satellite (GOES) at 4-hour intervals to the USGS National Water Information System database. Streamflow was computed from gage height data for the San Bernard River station by using a pre-existing rating curve, which relates gage height to instantaneous streamflow. This rating curve was developed using standard USGS procedures (Rantz and others, 1982). Stage-discharge relations could not be developed for the Dickinson Bayou and Armand Bayou gages because they are tidally influenced.

In addition to continuous hydrologic data collected at the three stations, instantaneous measurements of streamflow were made during each site visit using standard USGS procedures (Rantz and others, 1982; Simpson (2001). Depending on site conditions, velocities were measured using either Price pygmy velocity meters, Price type AA velocity meters, or acoustic Doppler current profilers (ADCPs). When conditions allowed, wading measurements were made and topsetting wading rods were used to measure the depth of flow and to suspend the velocity meter in the water column. When depths of flow or velocities were too great, 
measurements were made by suspending instruments from nearby bridges or by deploying a boat-mounted ADCP.

\section{Water-Quality Data}

\section{Continuously Monitored Water-Quality Properties}

Water temperature, specific conductance, $\mathrm{pH}$, and dissolved oxygen were measured using multi-probe water-quality meters and electronically recorded at 15minute intervals by the DCPs. In each application, the meters were installed near the center of flow and were operated as documented in Wagner and others (2000).

The continuous monitoring station in Dickinson Bayou (fig. 2; table 1) was located in a relatively deep (about $20 \mathrm{ft}$ ) section of the bayou. Because flow reverses with tidal fluctuations, the potential for stratification of water-quality properties associated with density differences between saltwater (heavier) and freshwater (lighter) existed. During field reconnaissance, the occurrence of a "salt-wedge" along the bottom was verified by measured differences in specific conductance with depth. The occurrence of such a wedge can lead to small dissolved oxygen concentrations at depths. Because of the stratification, three multi-probe water-quality monitors were deployed at the State Highway 3 bridge station, one near the bottom (depth about $18 \mathrm{ft}$ ), one near the center (depth about $10 \mathrm{ft}$ ), and one near the top (depth about $2 \mathrm{ft}$ ). The meter was operational during December 2000-September 2001.

The continuous monitoring station in Armand Bayou (fig. 2; table 1) was installed in a relatively wide (greater than $300 \mathrm{ft}$ ) and shallow (about $3 \mathrm{ft}$ ) section of the bayou. As was the case in Dickinson Bayou, the station was in the tidal segment of Armand Bayou. Because of the shallow depth, deployment of instruments at multiple depths was not practical. R.S. Burgess (Texas Commission on Environmental Quality, written commun., 2003) indicates that "density stratification due to both temperature and salinity" does occur in Armand Bayou and that "pronounced vertical gradients of dissolved oxygen" also have been observed at locations in the bayou. The multi-probe water-quality meter was set to a depth of about $2 \mathrm{ft}$. The meter was operational during December 2000-August 2001.

The continuous monitoring station in the San Bernard River (fig. 3; table 1) was installed in a riverine setting, with typical water depths of $3 \mathrm{ft}$ and constant flow. The multi-probe water-quality meter was deployed at a depth of about $2 \mathrm{ft}$, although the exact depth of the meter was dependent upon water depth at any given time. The range in stage at this station (about 3 to $33 \mathrm{ft}$ ) during the study was greater than the ranges at the stations in Dickinson and Armand Bayous. The meter was in place during December 2000-August 2002. However, because of vandalism, it was not operational from mid-July 2001 to mid-December 2001.

\section{Periodically Collected Water-Quality Properties and Constituents}

Selected water-quality properties and constituents were collected periodically and measured by laboratory analysis. Principally, these were nutrients (ammonia nitrogen, ammonia plus organic nitrogen, nitrite nitrogen, nitrite plus nitrate nitrogen, orthophosphorus), phytoplankton (chlorophyll-a, pheophytin), and indicator bacteria (fecal coliforms, fecal streptococci, E. coli, and enterococci). Five-day BOD and suspended sediment also were collected periodically at Armand Bayou and the San Bernard River. Laboratories responsible for each type of analysis are listed in table 2 .

The GCHD and TCEQ collected samples at Dickinson Bayou monthly during July 2000-August 2001 following TCEQ methods (Texas Natural Resource Conservation Commission, 1999). The GCHD laboratory analyzed the samples for ammonia nitrogen, nitrite plus nitrate nitrogen, orthophosphorus, fecal coliform bacteria, E. coli bacteria, and enterococci bacteria. The TCEQ laboratory analyzed the samples for ammonia plus organic nitrogen, chlorophyll-a, and pheophytin. All data were collected in conformance with a detailed Quality Assurance Project Plan (QAPP) that specified rigorous cleaning and sampling procedures and included the collection and analysis of appropriate QA samples. Analytical results for the monthly samples were obtained in electronic format from the GCHD and TCEQ.

The USGS collected water samples at Armand Bayou in August 2000 and in January, March, May, and July 2001. Water samples for Armand Bayou were collected and processed using standard USGS methods (U.S. Geological Survey, 1997-present).

The USGS collected water samples every other month at six sites in the San Bernard River during January 2001-August 2002. Again, water samples were collected and processed using standard USGS procedures. 
Table 2. Laboratories responsible for analyses of samples collected from Dickinson Bayou, Armand Bayou, and San Bernard River, Texas Gulf Coastal Plain, 2000-2002

[GCHD, Galveston County Health District; TCEQ, Texas Commission on Environmental Quality; USGS-NWQL, U.S. Geological Survey National Water Quality Laboratory; USGS-HOU, U.S. Geological Survey Houston Subdistrict; EcoAnalysts, EcoAnalysts Inc. contract laboratory]

\begin{tabular}{lllll}
\hline \multirow{2}{*}{ Water body } & \multicolumn{4}{c}{ Laboratory responsible for analysis } \\
\cline { 2 - 5 } & Nutrients & Phytoplankton & $\begin{array}{c}\text { Indicator } \\
\text { bacteria }\end{array}$ & $\begin{array}{c}\text { Benthic } \\
\text { macroinvertebrate }\end{array}$ \\
\hline Dickinson Bayou & GCHD/TCEQ & TCEQ & GCHD & USGS-NWQL \\
Armand Bayou & USGS-NWQL & USGS-NWQL & USGS-HOU & USGS-NWQL \\
San Bernard River & USGS-NWQL & USGS-NWQL & USGS-HOU & EcoAnalysts \\
\hline
\end{tabular}

Note: Five-day biochemical oxygen demand for Armand Bayou and San Bernard River analyzed by USGS Houston Subdistrict; suspended sediment for Armand Bayou and San Bernard River analyzed by USGS Louisiana District.

QA samples were collected at the same time that environmental samples were collected. Equipment blanks and field blanks were used to verify the adequacy of cleaning procedures. Split samples were used to determine the analytical precision (reproducibility) for various constituents. Concurrent samples were used to provide a measure of sampling precision (reproducibility) and to indicate spatial or temporal inhomogeneities in the system being sampled. Results of concurrent samples also can reflect differences in sampling, processing, and laboratory analysis. In the QAPP, the stated QA objective for sampling and analytical precision was a relative percent difference (RPD) of less than 20 percent. The RPDs of all split and concurrent samples were less than 20 percent. If equipment blanks or field blanks were greater than QA limits (two times the minimum reporting level or 10 percent of the environmental value), a remark code of "V" (indicating contamination) precedes the values listed in the associated tables.

\section{Biological Data}

Prior to biological sampling, appropriate stream reaches were selected. Potential reaches were identified using geographic information system (GIS) maps of the three water bodies. Final reaches were selected after onsite reconnaissance. A primary selection criterion was that a reach must contain a full meander (s-shaped curve) of the channel. The sampling sites are located within the selected stream reaches adjacent to the station locations listed in table 1 , and the frequency of each type of sampling in each water body is listed in table 3 .
Table 3. Biological sampling frequency in Dickinson Bayou, Armand Bayou, and San Bernard River, Texas Gulf Coastal Plain

[QMH, qualitative multi-habitat method; DTH, depositionaltargeted habitat method; RTH, richest-targeted habitat method]

\begin{tabular}{|c|c|c|}
\hline Water body & Data-collection activity & $\begin{array}{l}\text { Sampling } \\
\text { frequency }\end{array}$ \\
\hline \multirow{3}{*}{$\begin{array}{c}\text { Dickinson } \\
\text { Bayou }\end{array}$} & Stream habitat & Summer 2000 \\
\hline & Fish survey & $\begin{array}{l}\text { Summer } 2000 \\
\text { Winter } 2001 \\
\text { Summer } 2002\end{array}$ \\
\hline & $\begin{array}{l}\text { Benthic macroinvertebrate } \\
\text { sampling (QMH and } \\
\text { DTH methods) }\end{array}$ & $\begin{array}{l}\text { Summer } 2000 \\
\text { Winter } 2001 \\
\text { Summer } 2002\end{array}$ \\
\hline \multirow{3}{*}{$\begin{array}{r}\text { Armand } \\
\text { Bayou }\end{array}$} & Stream habitat & Summer 2000 \\
\hline & Fish survey & $\begin{array}{l}\text { Summary } \\
2000 \\
\text { Winter } 2001\end{array}$ \\
\hline & $\begin{array}{l}\text { Benthic macroinvertebrate } \\
\text { sampling (QMH, DTH, } \\
\text { and RTH methods) }\end{array}$ & $\begin{array}{l}\text { Summer } 2000 \\
\text { Winter } 2001\end{array}$ \\
\hline \multirow{3}{*}{$\begin{array}{l}\text { San Bernard } \\
\text { River }\end{array}$} & Stream habitat & Spring 2001 \\
\hline & Fish survey & $\begin{array}{l}\text { Summer } 2000 \\
\text { Spring } 2001 \\
\text { Summer } 2002\end{array}$ \\
\hline & $\begin{array}{l}\text { Benthic macroinvertebrate } \\
\text { sampling (QMH and } \\
\text { RTH methods) }\end{array}$ & $\begin{array}{l}\text { Summer } 2000 \\
\text { Spring } 2001 \\
\text { Spring 2002 }\end{array}$ \\
\hline
\end{tabular}


Fish, benthic macroinvertebrate, and streamhabitat data-collection methods used in Dickinson and Armand Bayous are summarized in Hogan (2002). The same methods were used to collect biological data in the San Bernard River.

\section{HYDROLOGIC DATA}

Figure 4a shows rainfall data collected at the NWS station at League City, and figure $4 b$ shows rainfall data collected at the NADP station at the Attwater Prairie Chicken National Wildlife Refuge near Sealy. Rainfall distributions for the two locations were similar in terms of timing and magnitude. However, in June 2001, more than 20 inches (in.) of rain was recorded at League City (Dickinson and Armand Bayous), most of which was associated with Tropical Storm Allison. The NADP station (San Bernard River) received much less rainfall (less than 2 in.) from this storm.

Figures $5 \mathrm{a}$ and $5 \mathrm{~b}$ show comparable gage height fluctuations between the Dickinson Bayou and Armand Bayou gages. The gage height timing and pattern were essentially the same at the two sites, but the magnitudes of tidal fluctuation were different. The dates of waterquality sample collection for the two sites also are shown.

Streamflow data were computed for the continuous monitoring station on the San Bernard River. Figure 6 shows the range in daily mean streamflow at the San Bernard River gage during the study period. The dates of water-quality sample collection also are shown.

\section{WATER-QUALITY DATA}

\section{Continuously Monitored Water-Quality Properties}

In addition to hydrologic data (stage and discharge) that were collected at one station in each of the three water bodies, water temperature, specific conductance, $\mathrm{pH}$, and dissolved oxygen also were collected at these three stations using multi-probe water-quality monitors. Boxplots show these data, grouped by month, for each of the three water bodies (figs. 7-10). Data are presented during November 2000-August 2001 because this was the only period when all three monitors were operational at the same time.

Seasonal variations in water-quality properties for all three sites are typical of those observed at USGS stations along the Texas Gulf Coast. In particular, water temperature (fig. 7) and dissolved oxygen (fig. 10) are inversely related. Periods of smallest dissolved oxygen concentrations generally occurred in the summer months when water temperatures were highest.

Because water-quality conditions were stratified during field reconnaissance, monitors were deployed at three depths at the Dickinson Bayou continuous monitoring station. Distributions of these water-quality parameters are shown in figure $11 \mathrm{a}-\mathrm{d}$. The boxplots indicate that water temperature was slightly higher near the surface than at mid-depth and near bottom; specific conductance increased with depth, particularly near bottom; $\mathrm{pH}$ was less variable near the surface; and dissolved oxygen concentrations decreased with depth. Examination of specific conductance data indicates that substantial stratification occurs through the water column. A salinity gradient that exceeded 6,000 microsiemens per centimeter at 25 degrees Celsius occurred at one station in summer months during periods of limited freshwater inflow. During these same periods, dissolved oxygen concentrations typically were much smaller in the bottom depths than at the middle and top depths. During periods of elevated streamflow (after rainfall), mixing occurred, and stratification was less prevalent.

\section{Periodically Collected Water-Quality Properties and Constituents}

Selected water-quality properties and constituents were analyzed for six sites in Dickinson Bayou (table 4, at end of report), four sites in Armand Bayou (table 5, at end of report), and six sites in the San Bernard River (table 6, at end of report). Graphical comparisons were made to show differences in selected waterquality constituents collected from the three water bodies. For these comparisons, data were grouped by water body, by flow condition, and by season. In addition, constituent yields were computed for selected constituents. Only water-quality constituents that were analyzed for all three water bodies were used for these comparisons and computations. The constituents are ammonia nitrogen, ammonia plus organic nitrogen, nitrite plus nitrate nitrogen, orthophosphorus, chlorophyll-a, pheophytin, fecal coliform bacteria, and $E$. coli bacteria.

The TCEQ has developed thresholds, or screening levels, for selected water-quality constituents that indicate elevated concentrations for constituents for which water-quality standards have not been adopted (Texas Commission on Environmental Quality, 2003). When sample concentrations exceed screening levels, they indicate a potential water-quality concern. 

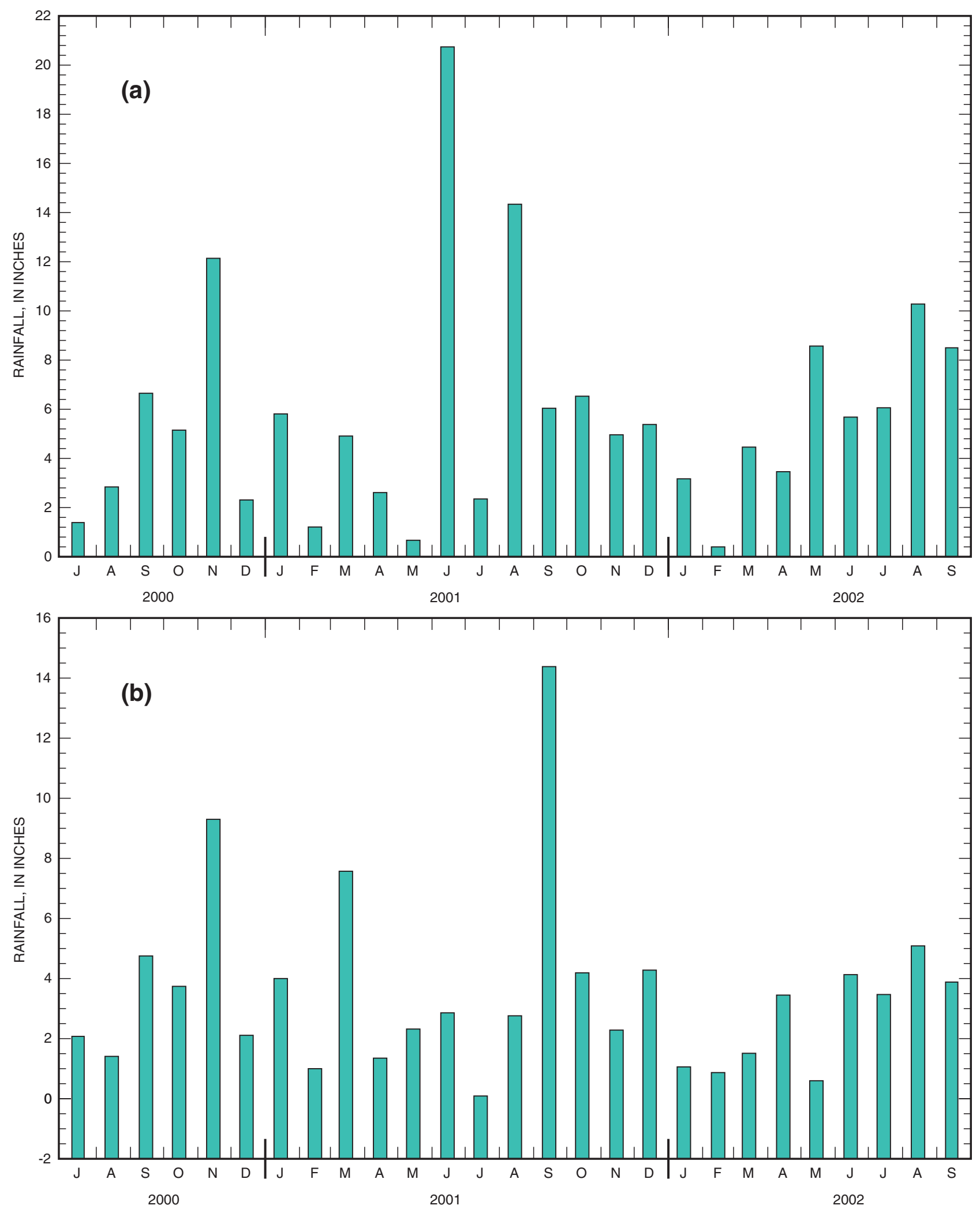

Figure 4. Rainfall at (a) National Weather Service station, League City, Texas, and (b) National Atmospheric Deposition Program station, Attwater Prairie Chicken National Wildlife Refuge near Sealy, Texas, July 2000September 2002. 


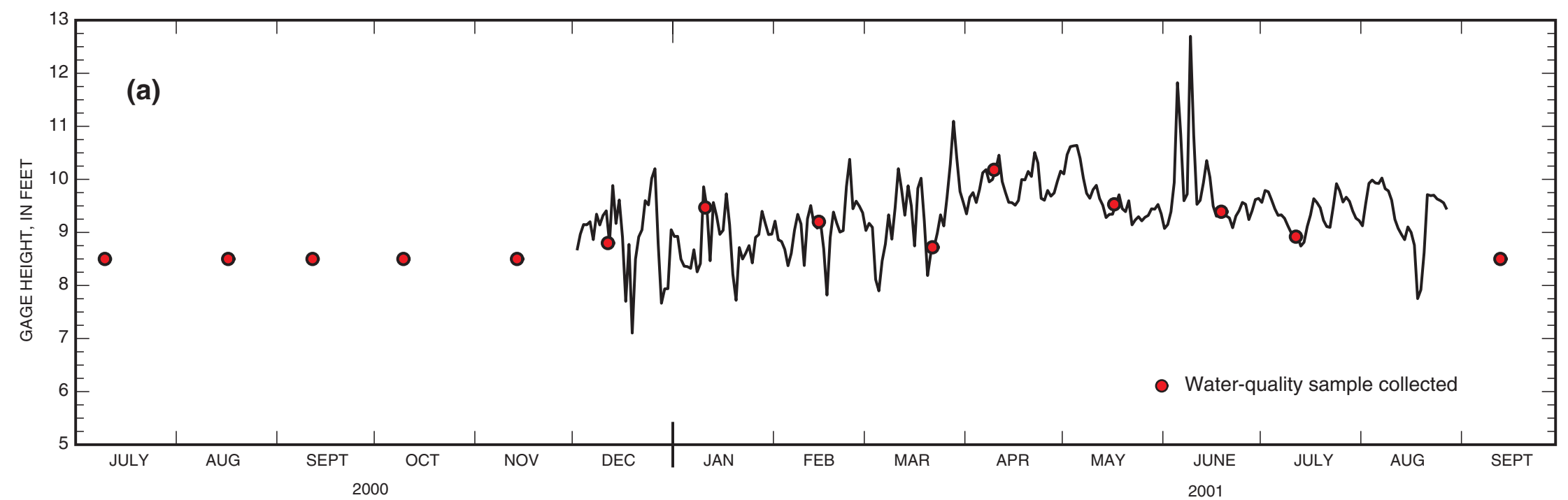

NOTE: Gage height not referenced to a particular datum

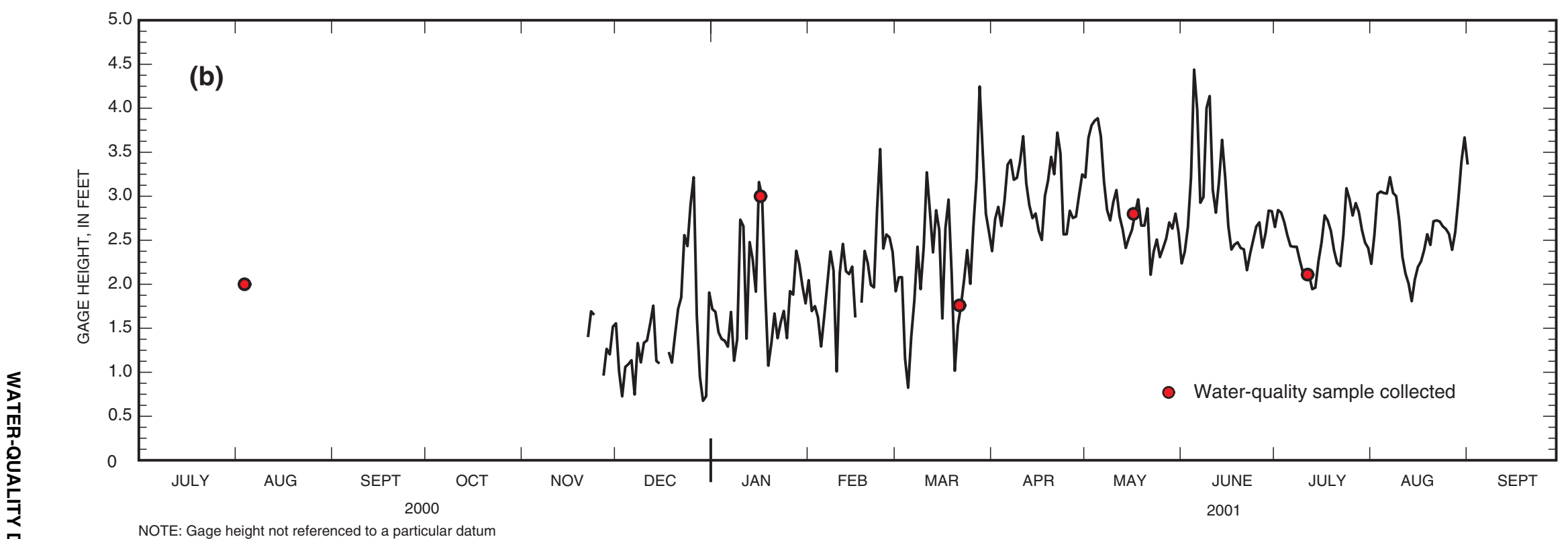

Figure 5. Hydrographs showing daily mean gage height and time of water-quality sampling at (a) station 08077647 Dickinson Bayou at State Highway 3, Dickinson, Texas, and (b) station 293546095052701 Armand Bayou at Bay Area Boulevard, Pasadena, Texas, July 2000-September 


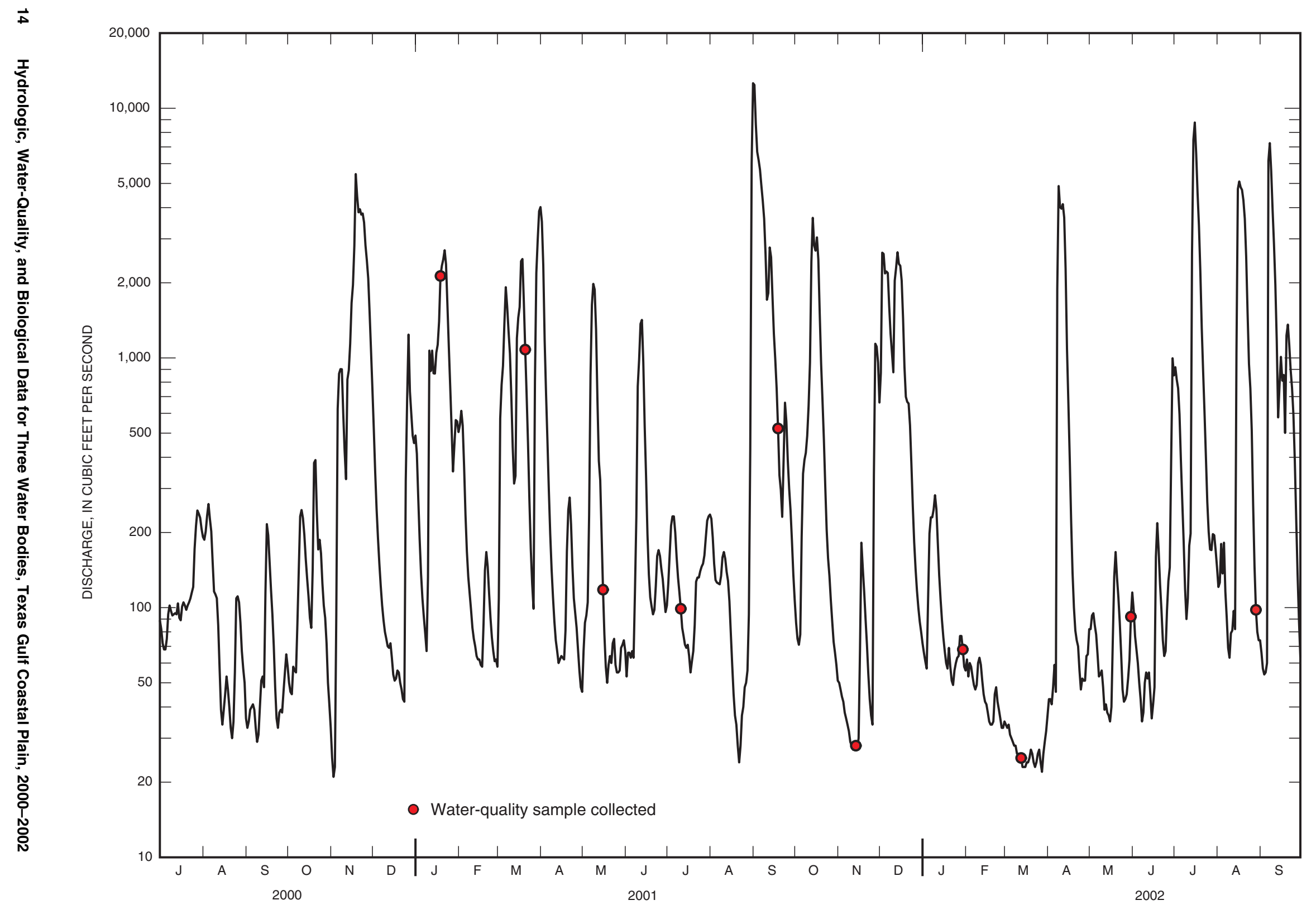

Figure 6. Hydrographs showing daily mean discharge and time of water-quality sampling at station 08117500 San Bernard River near Boling, Texas, July 2000-September 2002. 

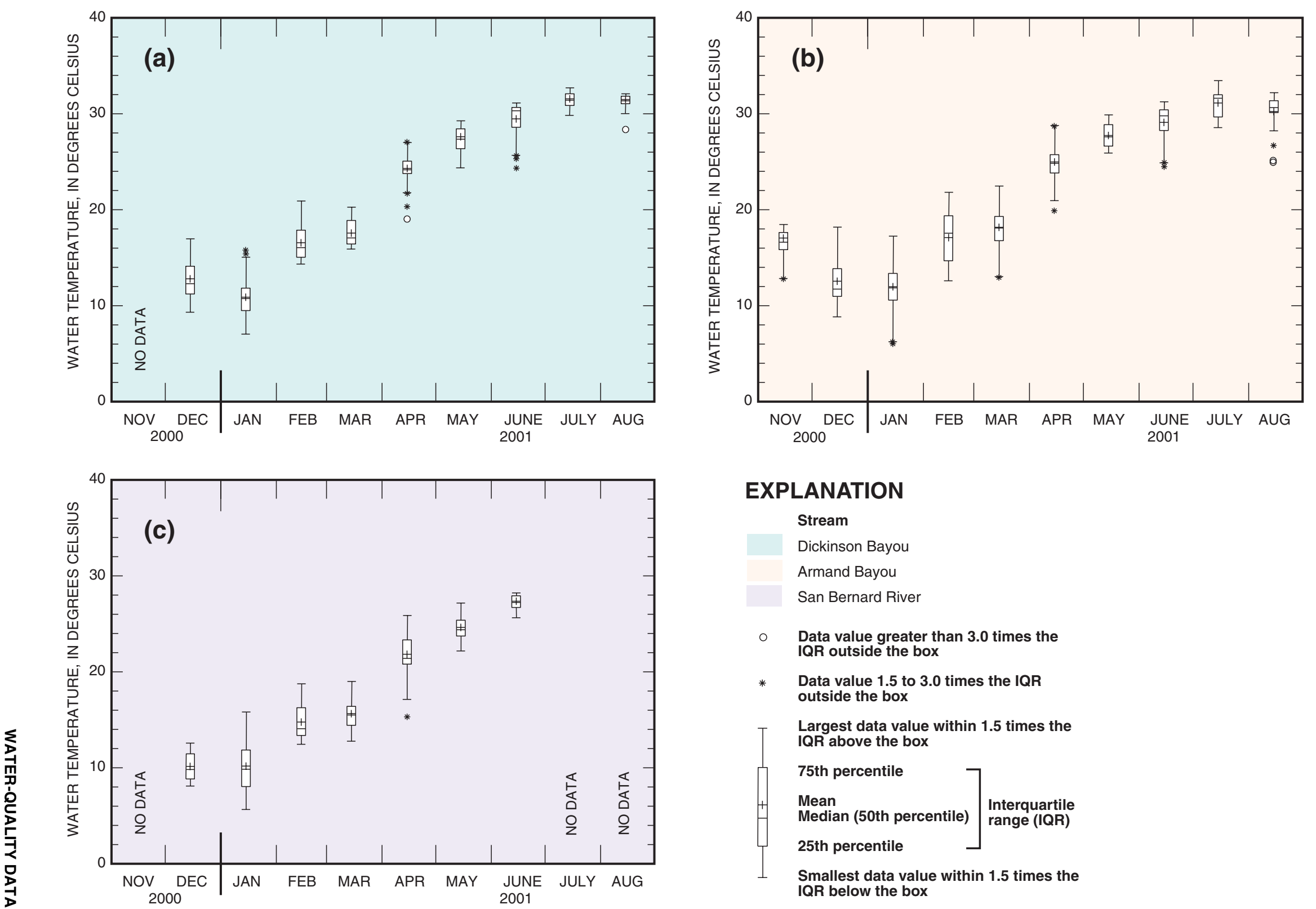

\section{EXPLANATION}

Stream

Dickinson Bayou

Armand Bayou

San Bernard River

- Data value greater than 3.0 times the QR outside the box

* Data value 1.5 to 3.0 times the IQR outside the box

Largest data value within 1.5 times the IQR above the box

75th percentile

$\begin{array}{ll}\text { Mean } & \text { Interquartile } \\ \text { range (IQR) }\end{array}$

25th percentile

Smallest data value within 1.5 times the IQR below the box

Figure 7. Distribution of continuously recorded (15-minute interval) water temperature in (a) Dickinson Bayou, (b) Armand Bayou, and (c) the San

Bernard River, Texas Gulf Coastal Plain, November 2000-August 2001. 

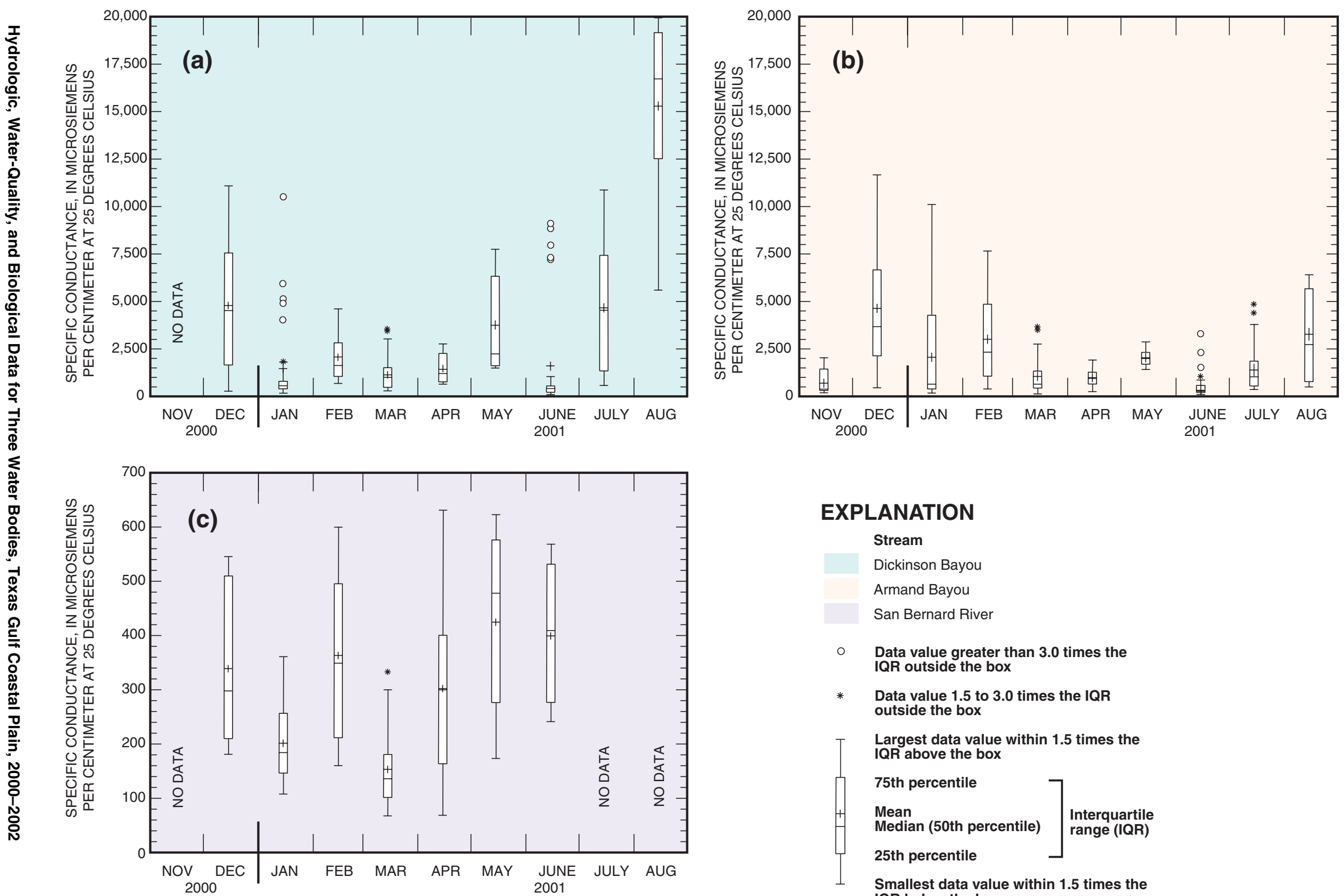

\section{EXPLANATION}

Stream

Dickinson Bayou

Armand Bayou

San Bernard River

- Data value greater than 3.0 times the QR outside the box

* Data value 1.5 to 3.0 times the IQR outside the box

Largest data value within 1.5 times the QR above the box

75th percentile

$\left.\begin{array}{l}\begin{array}{l}\text { Mean } \\ \text { Median (50th percentile) }\end{array} \\ \text { 25th percentile }\end{array}\right] \begin{aligned} & \text { Interquartile } \\ & \text { range (IQR) }\end{aligned}$

Smallest data value within 1.5 times the QR below the box

Figure 8. Distribution of continuously recorded (15-minute interval) specific conductance in (a) Dickinson Bayou, (b) Armand Bayou, and (c) the San Bernard River, Texas Gulf Coastal Plain, November 2000-August 2001. 

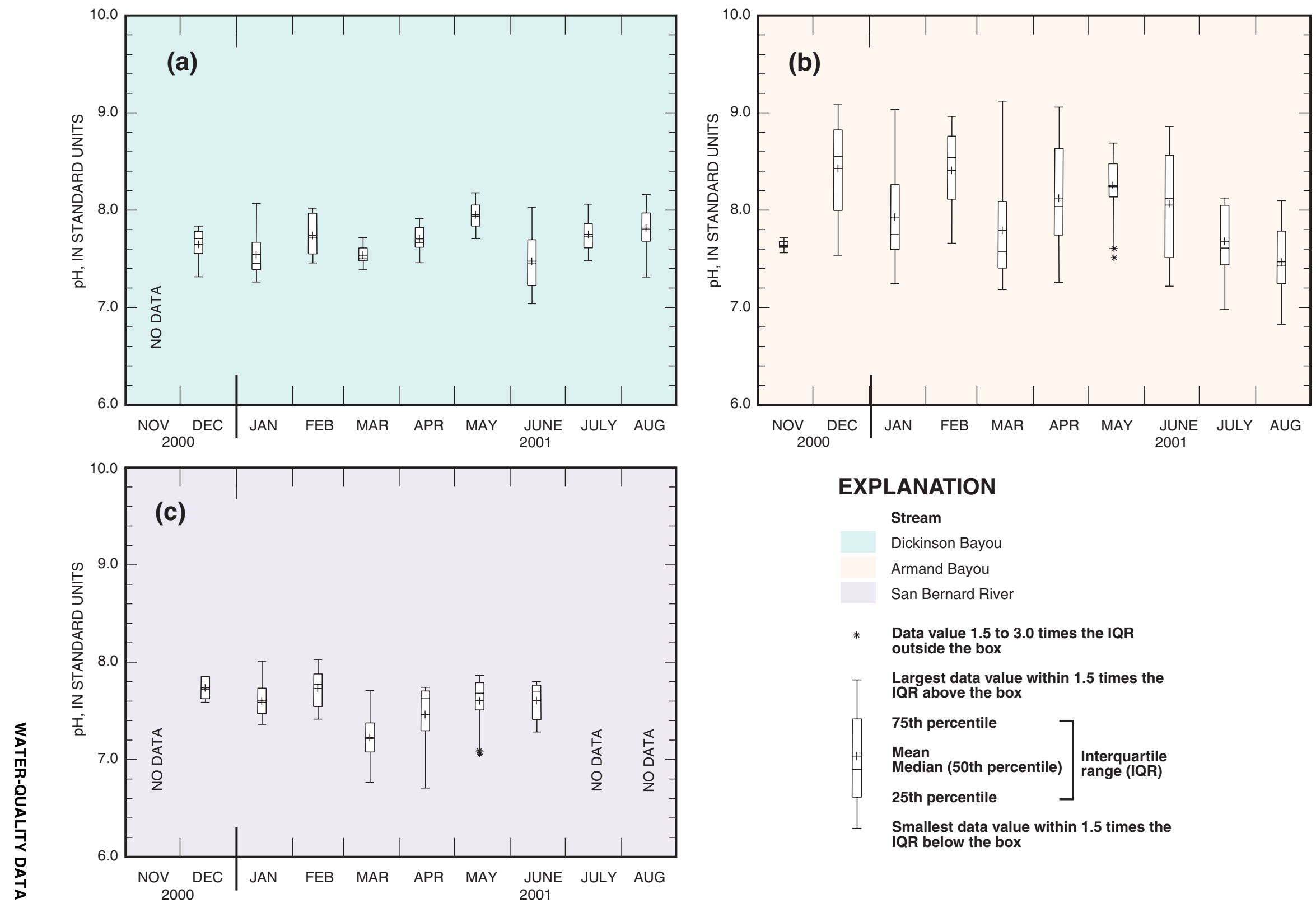

\section{EXPLANATION}

Stream

Dickinson Bayou

Armand Bayou

San Bernard River

* Data value 1.5 to 3.0 times the IQR outside the box

Largest data value within 1.5 times the QR above the box

75th percentile

Mean
Median (50th percentile)

Median (50th percentile) range (IQR)

25th percentile

Smallest data value within 1.5 times the IQR below the box

Figure 9. Distribution of continuously recorded (15-minute interval) pH in (a) Dickinson Bayou, (b) Armand Bayou, and (c) the San Bernard River, $\vec{v} \quad$ Texas Gulf Coastal Plain, November 2000-August 2001. 

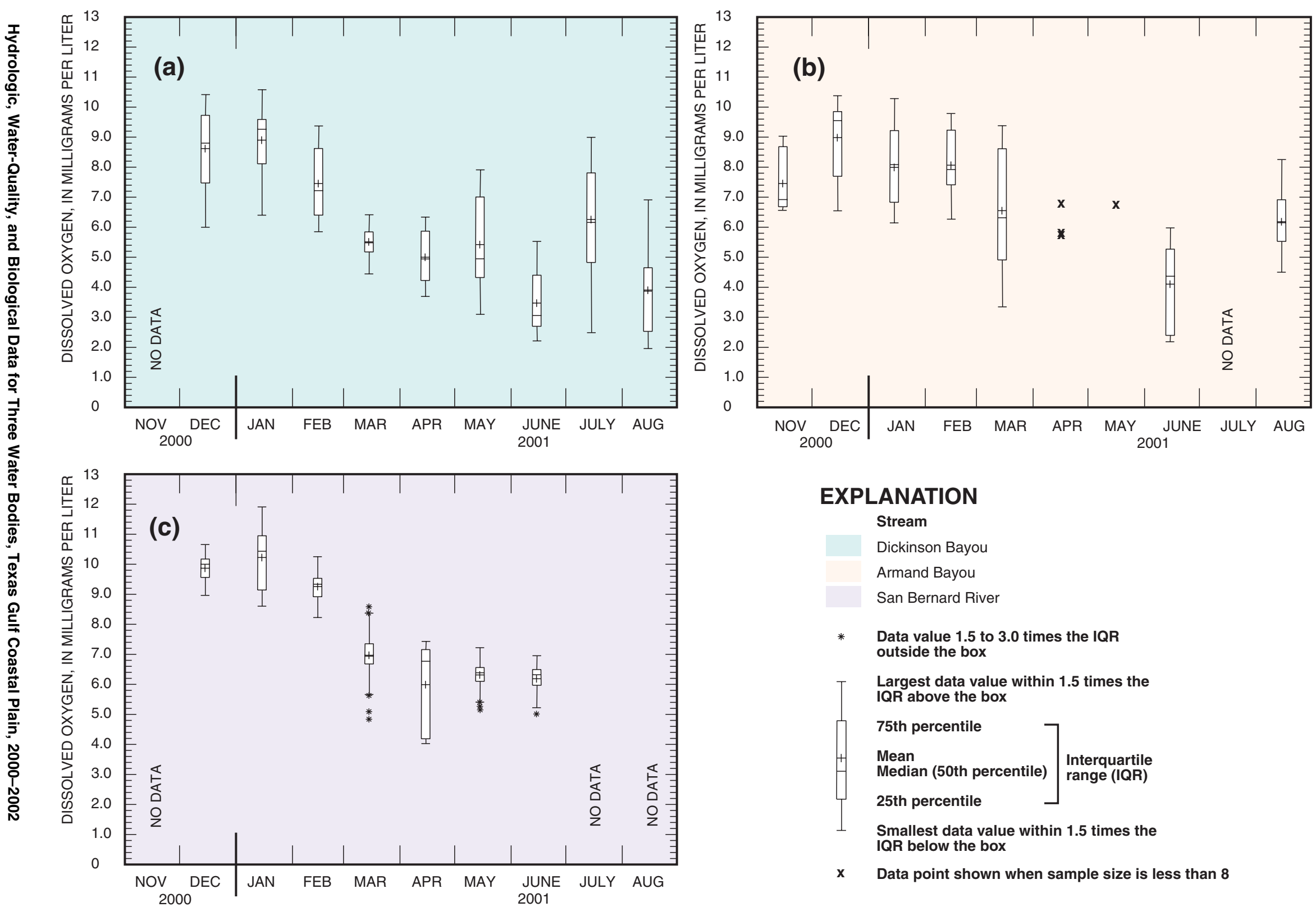

\section{EXPLANATION}

Stream

Dickinson Bayou

Armand Bayou

San Bernard River

* Data value 1.5 to 3.0 times the IQR outside the box

Largest data value within 1.5 times the IQR above the box

75th percentile

\begin{tabular}{l|l} 
Mean & $\begin{array}{l}\text { Interquartile } \\
\text { Median (50th percentile) } \\
\text { range (IQR) }\end{array}$
\end{tabular}

25th percentile

Smallest data value within 1.5 times the QR below the box

$\mathrm{X} \quad$ Data point shown when sample size is less than 8

Figure 10. Distribution of continuously recorded (15-minute interval) dissolved oxygen in (a) Dickinson Bayou, (b) Armand Bayou, and (c) the San Bernard River, Texas Gulf Coastal Plain, November 2000-August 2001. 

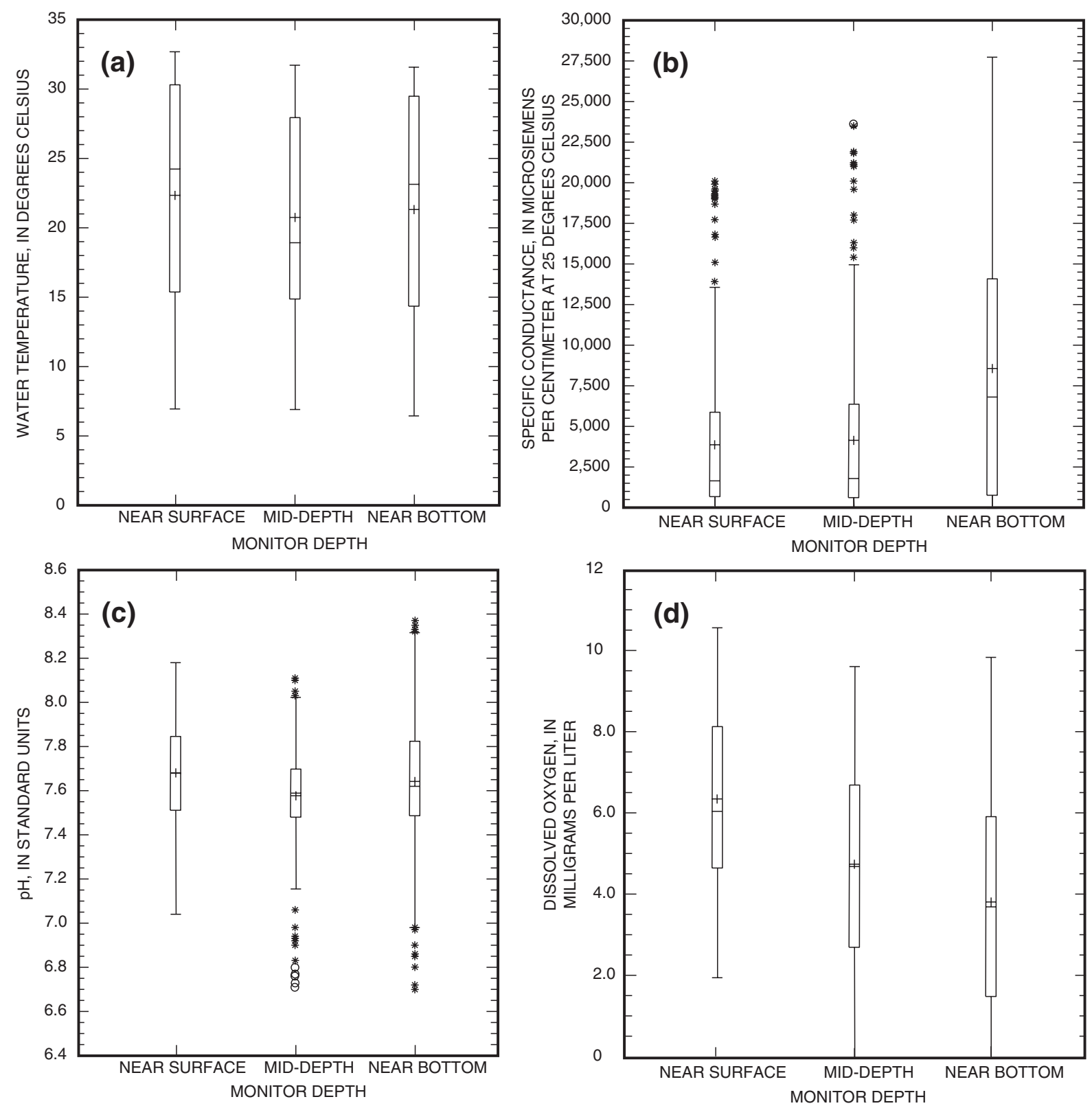

\section{EXPLANATION}

- Data value greater than 3.0 times the IQR outside the box

* Data value 1.5 to 3.0 times the IQR outside the box

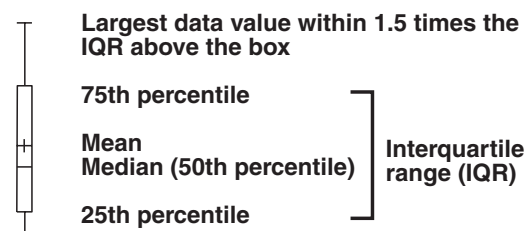

25th percentile

Smallest data value within 1.5 times the IQR below the box

Figure 11. Distribution of continuously recorded (15-minute interval) (a) water temperature, (b) specific conductance, (c) $\mathrm{pH}$, and (d) dissolved oxygen at three depths in Dickinson Bayou, Texas Gulf Coastal Plain, December 2000-August 2001. 
Table 7. Screening levels for selected nutrients (Texas Commission on Environmental Quality, 2003)

[mg/L, milligrams per liter; $\mu \mathrm{g} / \mathrm{L}$, micrograms per liter]

\begin{tabular}{lcccc}
\hline \multirow{2}{*}{$\begin{array}{c}\text { Stream } \\
\text { type }\end{array}$} & $\begin{array}{c}\text { Ammonia } \\
\text { nitrogen } \\
(\mathbf{m g} / \mathbf{L})\end{array}$ & $\begin{array}{c}\text { Nitrite plus } \\
\text { nitrate nitrogen } \\
(\mathbf{m g} / \mathbf{L})\end{array}$ & $\begin{array}{c}\text { Orthophosphorus } \\
(\mathbf{m g} / \mathbf{L})\end{array}$ & $\begin{array}{c}\text { Chlorophyll-a } \\
(\mu \mathbf{g} / \mathbf{L})\end{array}$ \\
\hline Freshwater & 0.17 & 2.76 & 0.80 & 11.6 \\
Tidal & .58 & 1.83 & .71 & 19.2 \\
\hline
\end{tabular}

Screening levels for selected nutrients have been developed for freshwater streams, tidal streams (table 7), reservoirs, and estuaries.

\section{Nutrients}

Distributions of ammonia nitrogen, ammonia plus organic nitrogen, nitrite plus nitrate nitrogen, and orthophosphorus concentrations are shown by boxplots grouped by water body (fig. 12). Dickinson Bayou had the largest median ammonia nitrogen concentration; the San Bernard River had the smallest median concentration but the largest range in concentration. Armand Bayou had the largest median concentrations of ammonia plus organic nitrogen, nitrite plus nitrate nitrogen, and orthophosphorus.

The effect of variations in stream discharge on nutrient concentrations is evident when these data are grouped by flow condition (fig. 13). Samples collected during base-flow conditions were designated low flow, and samples collected during above base flow conditions were designated high flow. The median concentration of each of the four nutrients was larger for highflow samples than for low-flow samples. However, the largest individual concentrations and ranges in concentration occurred in low-flow samples.

Seasonality was reflected by grouping data from all three water bodies by the time of the year they were collected (fig. 14). Samples collected during September-November were designated fall; December-February, winter; March-May, spring; and June-August,

summer. Although no discernible pattern of seasonality was evident, the largest individual concentrations and ranges in concentration occurred during spring and summer (growing seasons).

\section{Chlorophyll-a and Pheophytin}

Both the median and individual concentrations of chlorophyll-a were largest for Armand Bayou (fig. 15).
Median concentrations of pheophytin were similar for all three water bodies (all less than 5 micrograms per liter $[\mu \mathrm{g} / \mathrm{L}])$. The largest individual pheophytin concentrations were from Armand Bayou.

Chlorophyll-a and pheophytin concentrations were grouped by flow condition (low flow and high flow, as per nutrients) in boxplots (fig. 16). The median concentrations of low-flow and high-flow samples were similar, less than $5 \mu \mathrm{g} / \mathrm{L}$ for both. However, the largest individual concentrations of each were measured in low-flow samples. The distributions are similar to those of nutrient concentrations grouped by flow condition (fig. 13).

Seasonal distributions of chlorophyll-a and pheophytin are shown in figure 17. The largest median concentration of chlorophyll-a is in summer, and the largest median concentration of pheophytin is in spring. Similar to seasonally grouped nutrient concentrations (fig. 14), the largest individual concentrations of chlorophyll-a and pheophytin occurred in the spring and summer, during the growing seasons.

\section{Indicator Bacteria}

Median densities of fecal coliform bacteria and E. coli bacteria were similar in all three water bodies (fig. 18). However, densities of both bacteria varied over wide ranges, particularly in Dickinson Bayou.

Fecal coliform bacteria and $E$. coli bacteria densities grouped by flow condition in boxplots (fig. 19) show that the largest median and individual bacteria densities were in samples collected during high flow. High flows contain a larger proportion of surface runoff, which can transport bacteria.

Seasonal distribution of fecal coliform bacteria and $E$. coli bacteria is shown in figure 20 . The median densities for both bacteria were largest during winter. The largest individual densities for both bacteria occurred during fall and winter. Seasonal distribution 

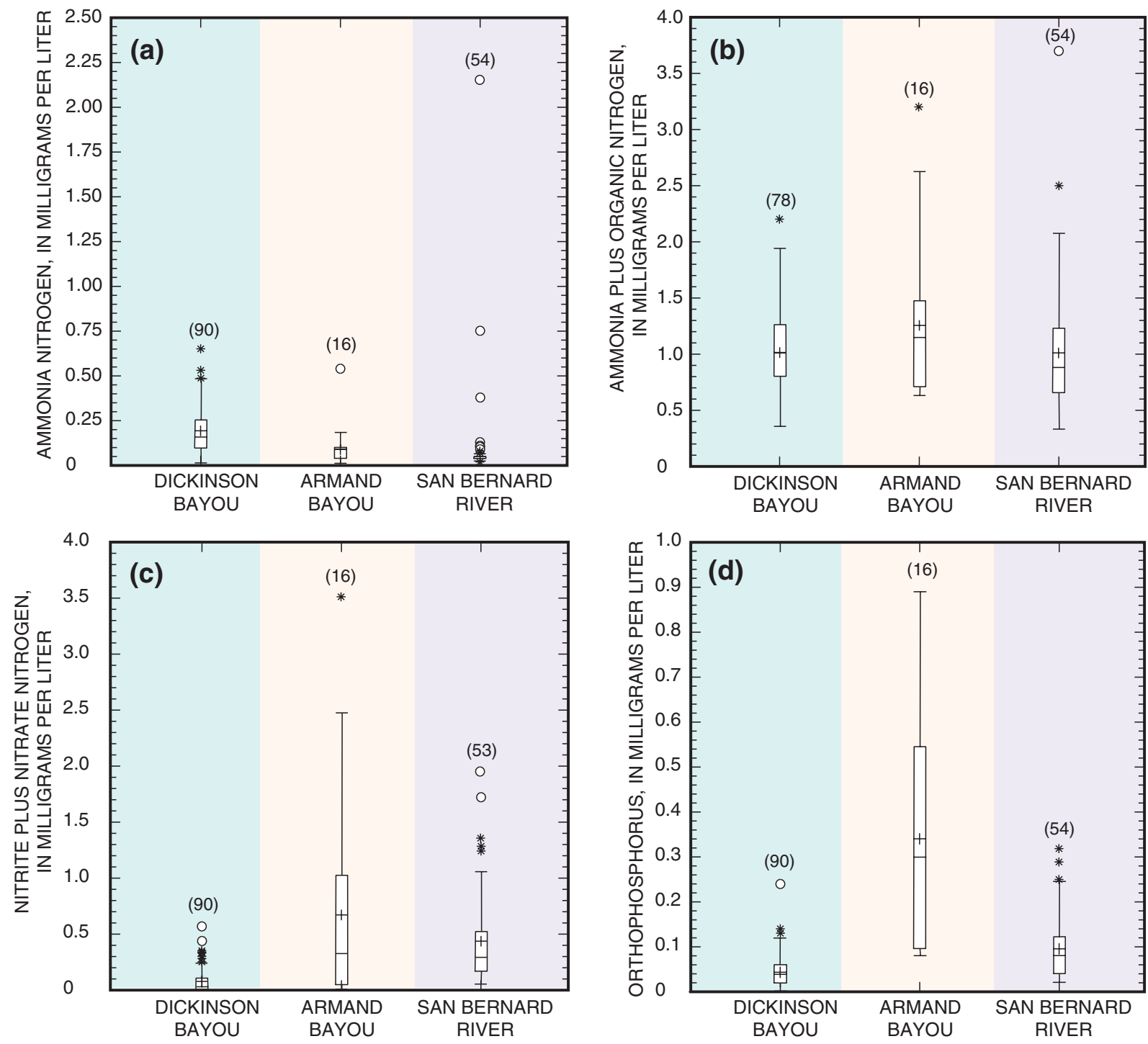

\section{EXPLANATION}

(16) Sample size

○ Data value greater than 3.0 times the IQR outside the box

* Data value 1.5 to 3.0 times the IQR outside the box

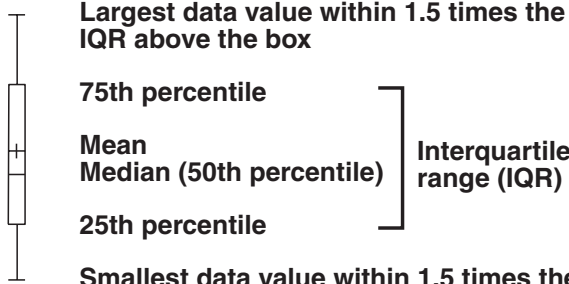

Smathe 1.5 times the IQR below the box

Figure 12. Distribution of periodically collected (a) ammonia nitrogen, (b) ammonia plus organic nitrogen, (c) nitrite plus nitrate nitrogen, and (d) orthophosphorus concentrations in Dickinson Bayou, Armand Bayou, and the San Bernard River, Texas Gulf Coastal Plain, 2000-2002. 

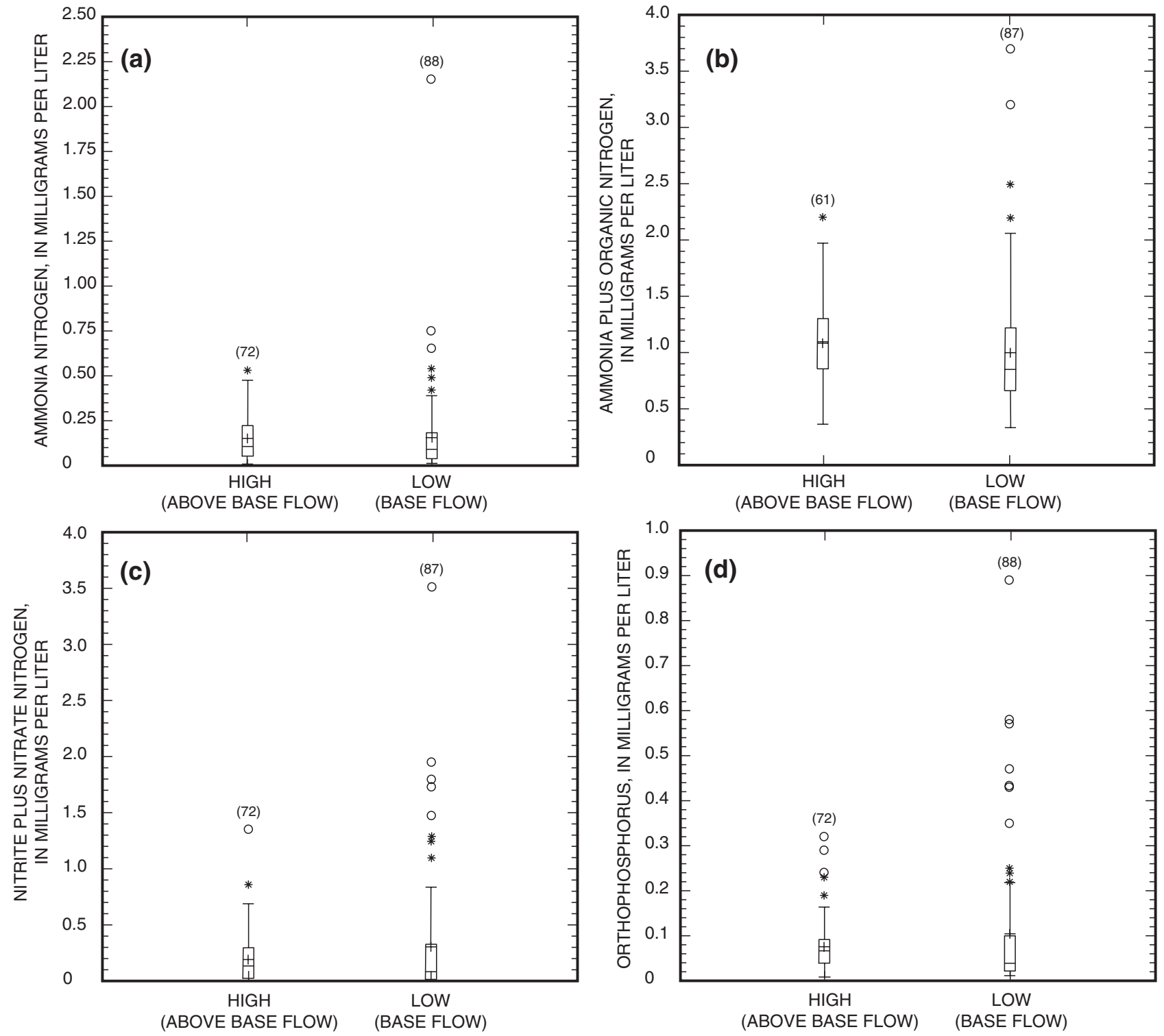

\section{EXPLANATION}

(61) Sample aize

- Data value greater than 3.0 times the IQR outside the box

* Data value 1.5 to 3.0 times the IQR outside the box

Largest data value within 1.5 times the IQR above the box

75th percentile

Mean

Median (50th percentile)

Interquartile

range (IQR)

25th percentile

Smallest data value within 1.5 times the IQR below the box

Figure 13. Distribution of periodically collected (a) ammonia nitrogen, (b) ammonia plus organic nitrogen, (c) nitrite plus nitrate nitrogen, and (d) orthophosphorus concentrations during high- and low-flow conditions in Dickinson Bayou, Armand Bayou, and the San Bernard River, Texas Gulf Coastal Plain, 2000-2002. 

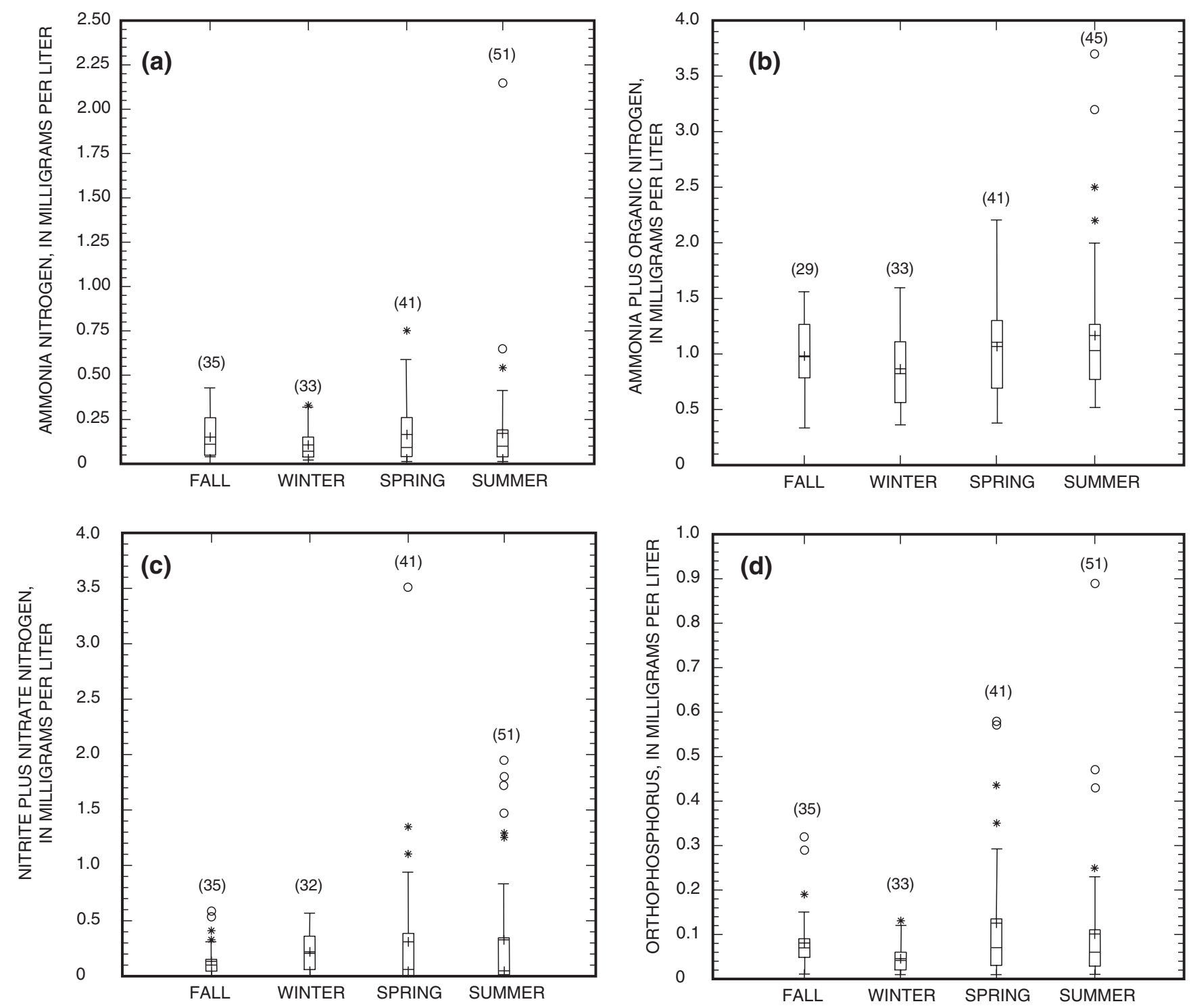

\section{EXPLANATION}

(29) Sample size

- Data value greater than 3.0 times the IQR outside the box

* Data value 1.5 to 3.0 times the IQR outside the box

Largest data value within 1.5 times the IQR above the box

75th percentile

Mean

Median (50th percentile) $\begin{aligned} & \text { Interquartile } \\ & \text { range (IQR) }\end{aligned}$

25th percentile

Smallest data value within 1.5 times the IQR below the box

Figure 14. Seasonal distribution of periodically collected (a) ammonia nitrogen, (b) ammonia plus organic nitrogen, (c) nitrite plus nitrate nitrogen, and (d) orthophosphorus concentrations in Dickinson Bayou, Armand Bayou, and the San Bernard River, Texas Gulf Coastal Plain, 2000-2002. 

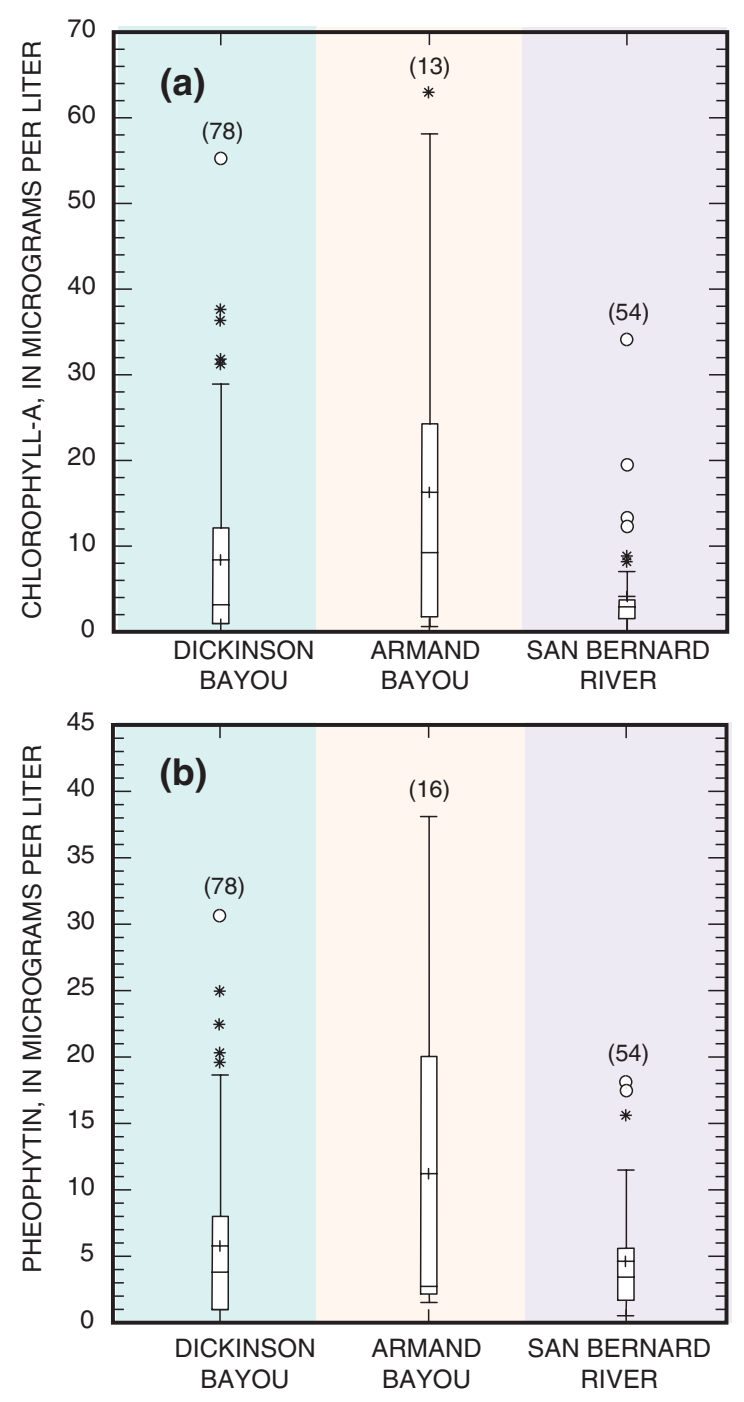

\section{EXPLANATION}

(16) Sample size

- Data value greater than 3.0 times the IQR outside the box

* Data value 1.5 to 3.0 times the IQR outside the box

Largest data value within 1.5 times the IQR above the box

75th percentile

Mean
Median (50th percentile)

25th percentile

Smallest data value within 1.5 times the IQR below the box

Figure 15. Distribution of periodically collected (a) chlorophyll-a and (b) pheophytin concentrations in Dickinson Bayou, Armand Bayou, and the San Bernard River, Texas Gulf Coastal Plain, 20002002.
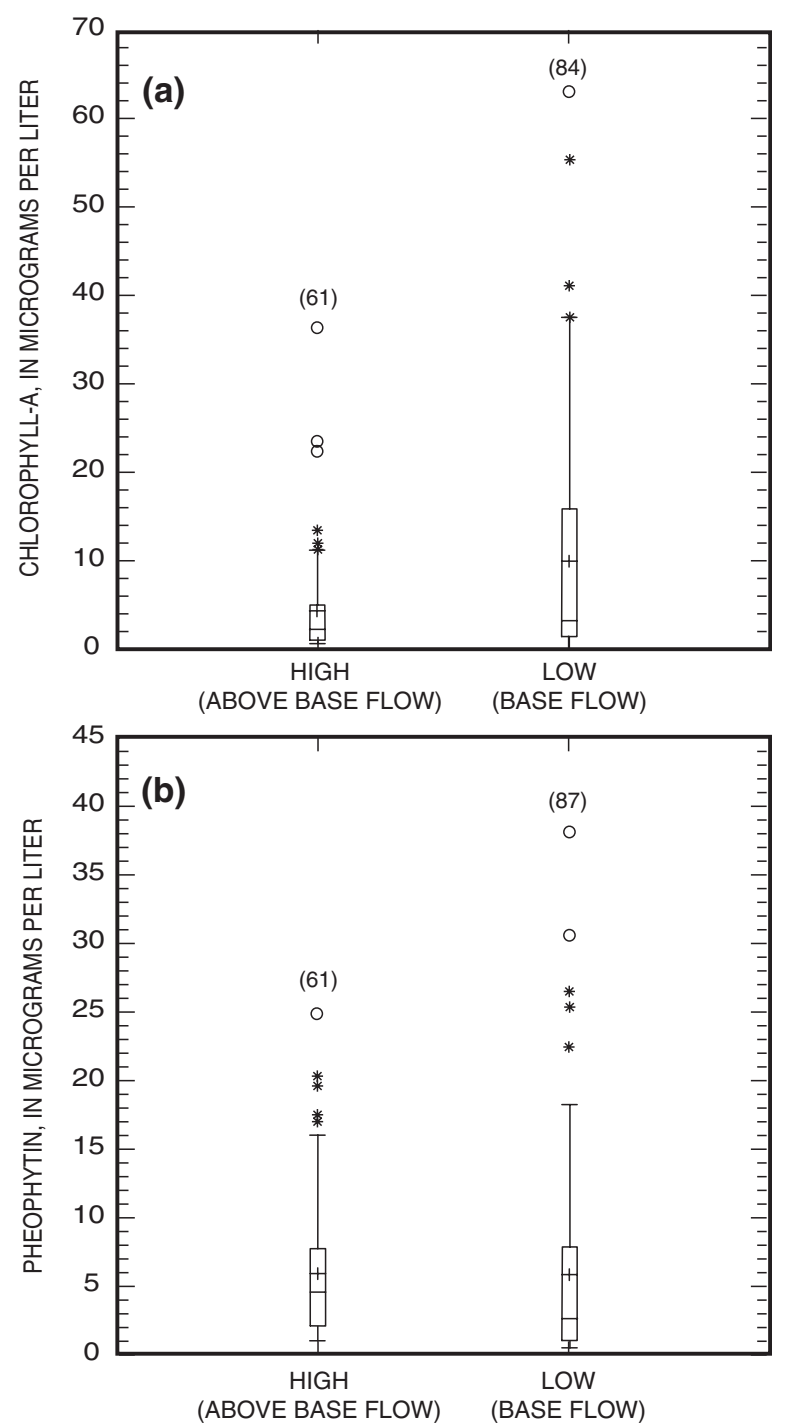

\section{EXPLANATION}

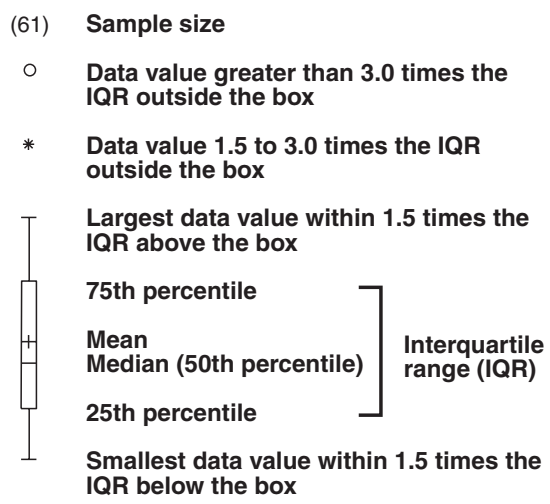

Figure 16. Distribution of periodically collected (a) chlorophyll-a and (b) pheophytin concentrations during high- and low-flow conditions in Dickinson Bayou, Armand Bayou, and the San Bernard River, Texas Gulf Coastal Plain, 2000-2002. 

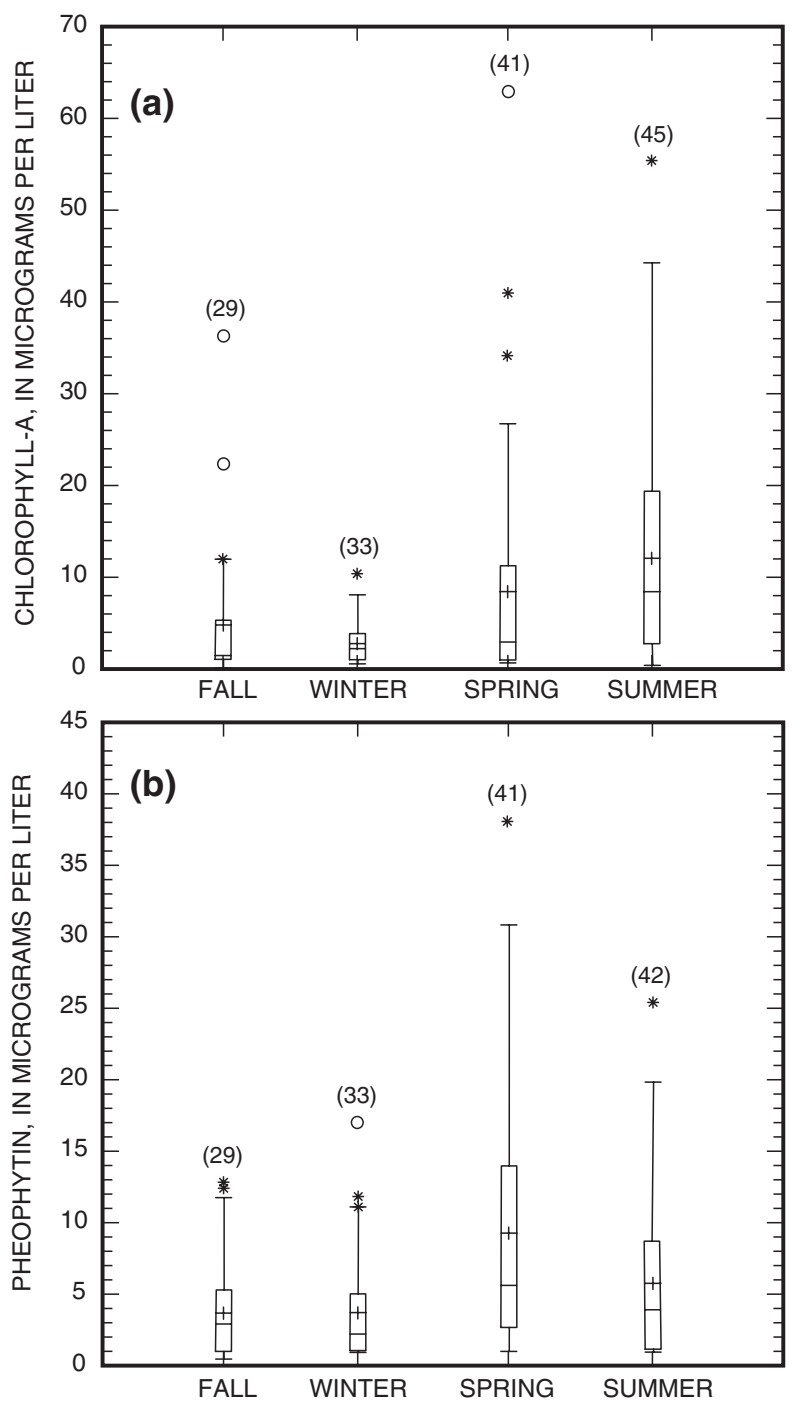

\section{EXPLANATION}

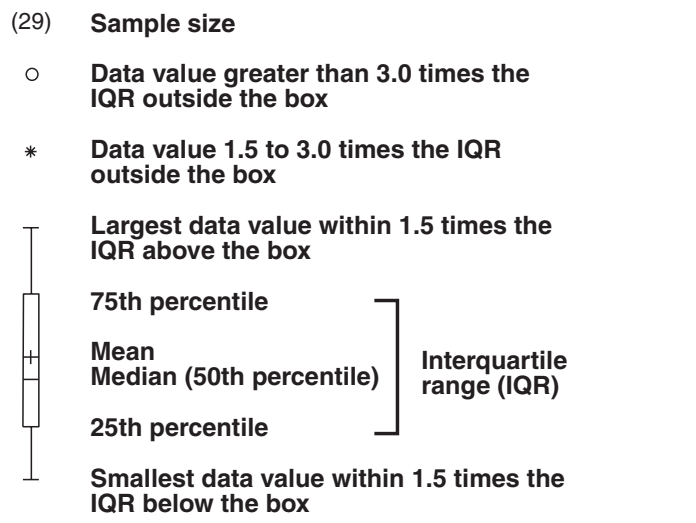

Figure 17. Seasonal distribution of periodically collected (a) chlorophyll-a and (b) pheophytin concentrations in Dickinson Bayou, Armand Bayou, and the San Bernard River, Texas Gulf Coastal Plain, 2000-2002.
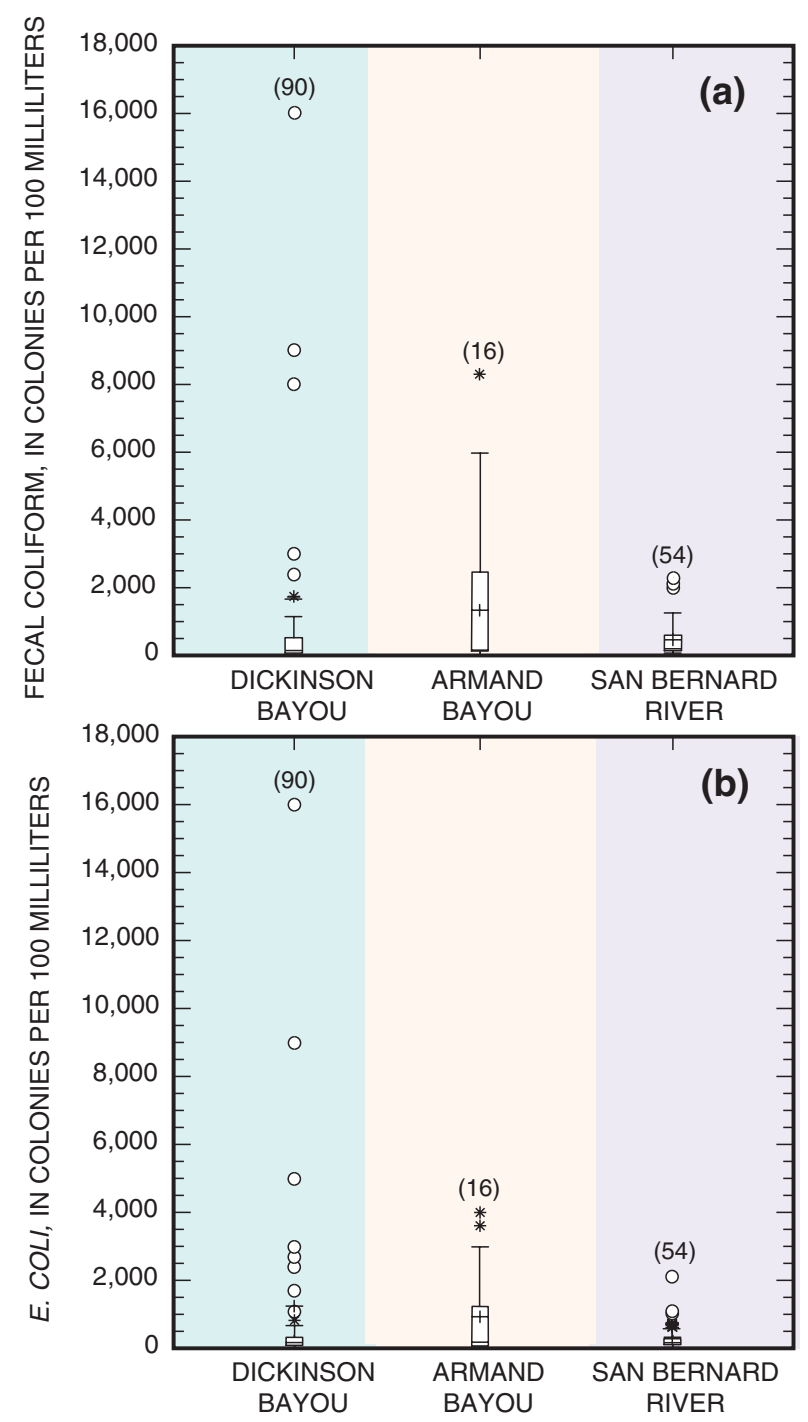

\section{EXPLANATION}

(15) Sample size

- Data value greater than 3.0 times the IQR outside the box

* Data value 1.5 to 3.0 times the IQR outside the box

Largest data value within 1.5 times the IQR above the box

75th percentile

Mean Interquartile Median (50th percentile) range (IQR)

25th percentile

Smallest data value within 1.5 times the IQR below the box

Figure 18. Distribution of periodically collected (a) fecal coliform bacteria and (b) E. coli bacteria densities in Dickinson Bayou, Armand Bayou, and the San Bernard River, Texas Gulf Coastal Plain, 20002002. 

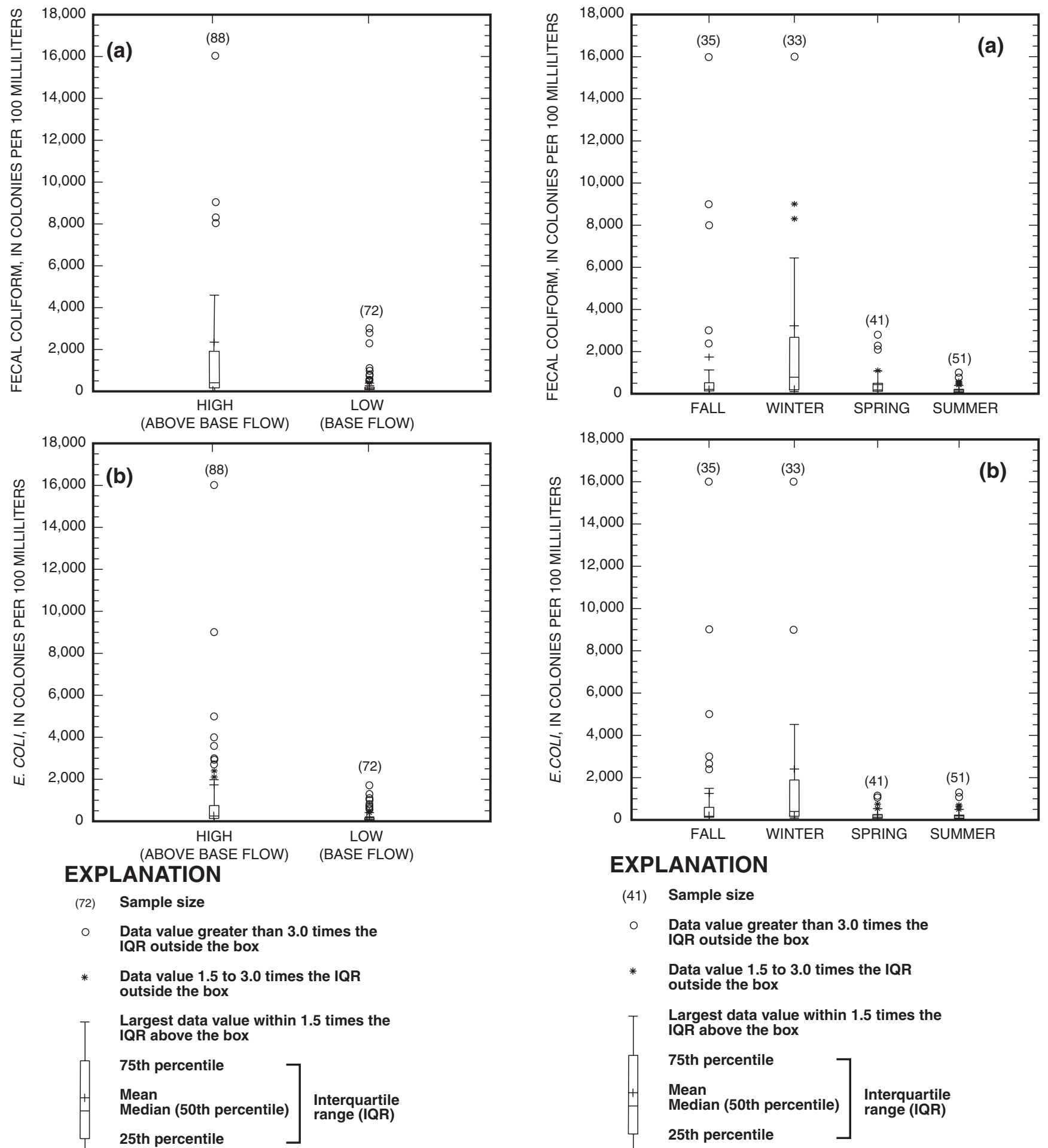

Smallest data value within 1.5 times the Smallest data value
IQR below the box

Figure 19. Distribution of periodically collected (a) fecal coliform bacteria and (b) E. coli bacteria densities during high- and low-flow conditions in Dickinson Bayou, Armand Bayou, and the San Bernard River, Texas Gulf Coastal Plain, 2000-2002.

\begin{abstract}
(41) Sample size
○ Data value greater than $\mathbf{3 . 0}$ times the IQR outside the box

* Data value 1.5 to 3.0 times the IQR outside the box

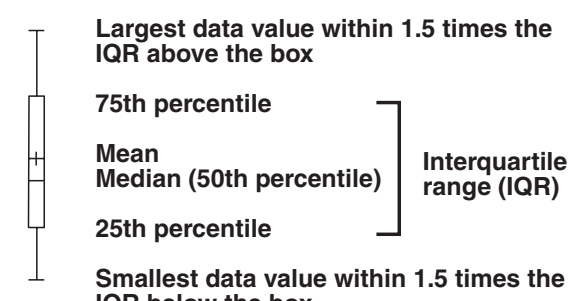
IQR below the box
\end{abstract}

Figure 20. Seasonal distribution of periodically collected (a) fecal coliform bacteria and (b) E. coli bacteria densities in Dickinson Bayou, Armand Bayou, and the San Bernard River, Texas Gulf Coastal Plain, 2000-2002. 
likely is related to flow conditions-the high-flow sampling events occurred during November and January.

\section{Nutrient Yields}

A constituent load for a stream is the product of a constituent concentration and streamflow and is the mass of a given constituent that is transported past a site on a stream during a specified period. The instantaneous load for a stream (Terrio, 1995) is computed as

$$
\operatorname{LOAD}(\mathrm{i})=\mathrm{FLOW}(\mathrm{i}) \times \mathrm{CONC}(\mathrm{i}) \times \mathrm{CF} \text {, }
$$

where

LOAD = constituent load at time $\mathrm{i}$, in pounds per day; FLOW $=$ discharge at time $i$, in cubic feet per second; CONC $=$ concentration of constituent at time $i$, in milligrams per liter; and

$\mathrm{CF}=$ conversion factor of 5.394.

Yield is a measure of the load-producing characteristics of a subbasin and is computed by dividing load by the area of the contributing subbasin,

$$
\text { YIELD }=(\mathrm{LOAD}) /(\mathrm{DA}) \text {, }
$$

where

$$
\begin{gathered}
\text { YIELD = constituent yield }, \text { in pounds per day per } \\
\text { square mile; and } \\
\text { DA = area of contributing subbasin, in square } \\
\text { miles. }
\end{gathered}
$$

Constituent yield data can be used to make direct comparisons of constituent contributions between subbasins with different drainage areas, while minimizing differences associated with varying streamflow.

Figures 21-24 show distributions of constituent yields for samples collected at each sampling station in the three water bodies for ammonia nitrogen, ammonia plus organic nitrogen, nitrite plus nitrate nitrogen, and orthophosphorus, respectively. The sampling stations are in downstream order in the boxplots. For most nutrients, the yield tended to increase with distance downstream, although this characteristic applied less to yields at San Bernard River sites than at Dickinson and Armand Bayou sites.

For each of the three water bodies, the yields were grouped by flow condition (low flow and high flow) (fig. 25). Constituent yields for the San Bernard River typically were less than constituent yields for Dickinson and Armand Bayous, during both low-flow and highflow conditions. Also, median yields of ammonia plus organic nitrogen, nitrite plus nitrate nitrogen, and orthophosphorus were larger for Armand Bayou than for the two other water bodies.

One possible explanation for larger yields for sites in Armand Bayou are anthropogenic effects related to land use in the watershed. Detailed maps of land use in the three water bodies were unavailable at the time of this report. However, a surrogate for land use in a given watershed is population density (number of people per square mile). Population density was computed for the drainage area upstream of each sampling site by overlaying watershed boundaries from 7.5-minute digital elevation model data (Texas Natural Resources Information System, 2003) on 2000 Census block data (U.S. Census Bureau, 2003) using GIS. The computed population density for the most downstream sampling site on the main stem of Armand Bayou (ARM03, fig. 2, table 1) was about 1,940 people per square mile; the population density for the most downstream sampling site in Dickinson Bayou (DCK05, fig. 2, table 1) was about 502 people per square mile. The computed population density for the most downstream sampling site in the San Bernard River (SANB03, fig. 3, table 1) was about 32 people per square mile. A larger population density indicates a more urbanized watershed. East and others (1998) found that nutrient concentrations in a stream that drained an urbanized watershed in Houston were appreciably larger than nutrient concentrations in Dickinson Bayou, which was less urbanized. Similarly, it is likely that some of the differences in the nutrient yields of Dickinson Bayou, Armand Bayou, and the San Bernard River are related to differences in land use in the respective drainage areas.

\section{BIOLOGICAL DATA}

To measure the status of in-stream biological resources, selected data were collected from each of the three water bodies to define fish and benthic macroinvertebrate community structure and to define streamhabitat conditions. In general, biological data for Dickinson and Armand Bayous are comparable because of their common hydrologic setting (tidally influenced, brackish water), and biological data for the San Bernard River are less comparable because they are from a riverine setting.

\section{Fish Data}

Fish taxa and individual counts of fish for Dickinson and Armand Bayous were presented previously in 

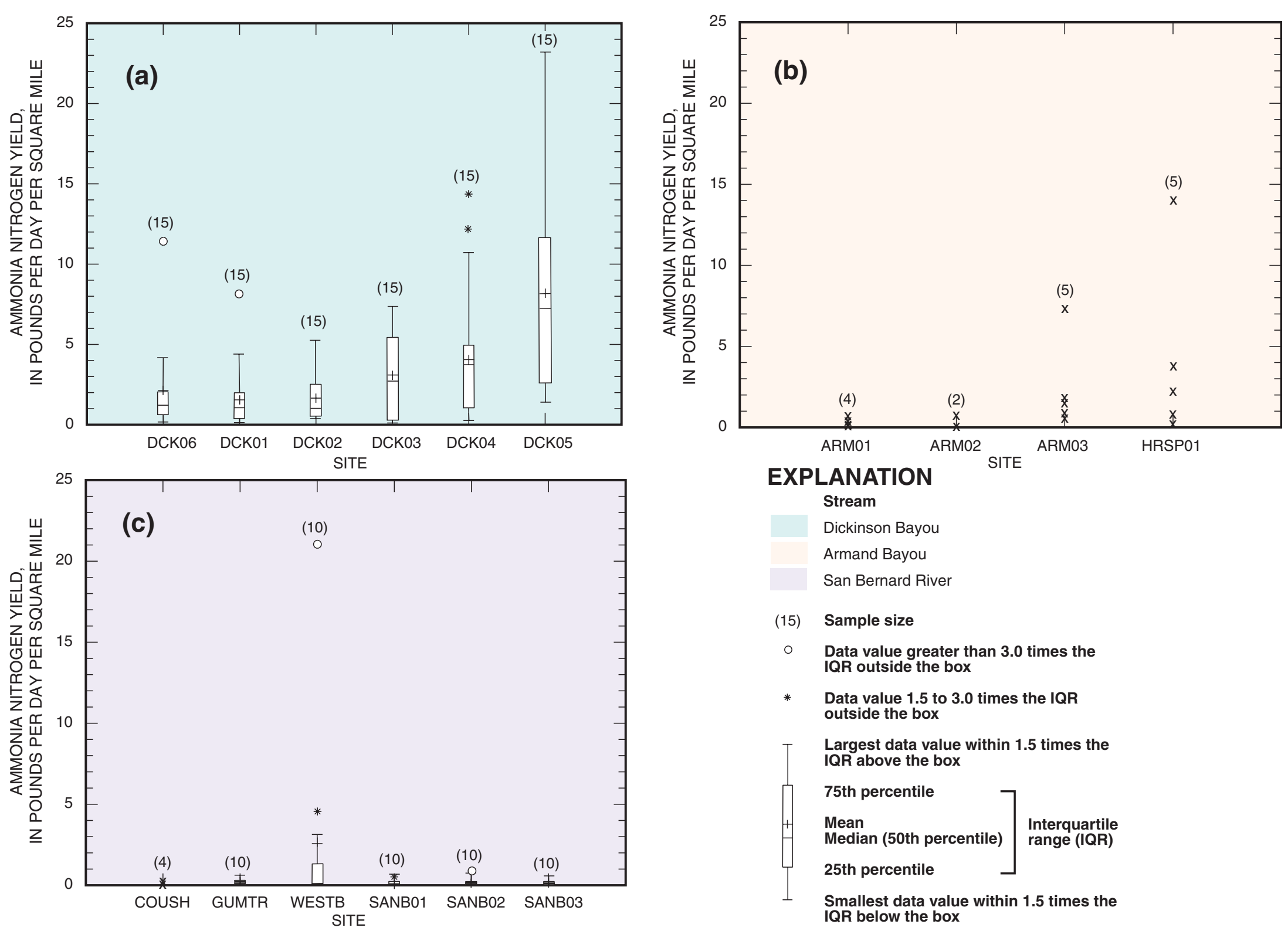

Stream

Dickinson Bayou

Armand Bayou

San Bernard River

(15) Sample size

- Data value greater than 3.0 times the IQR outside the box

* Data value 1.5 to 3.0 times the IQR outside the box

Largest data value within 1.5 times the IQR above the box

75th percentile

\begin{tabular}{l|l} 
Mean & \multicolumn{1}{|l}{ Median (50th percentile) } \\
range (IQR)
\end{tabular}

25th percentile

Smallest data value within 1.5 times the IQR below the box

$x \quad$ Data point shown when sample size is less than 10

Figure 21. Yields of periodically collected ammonia nitrogen for selected sites in (a) Dickinson Bayou, (b) Armand Bayou, and (c) the San Bernard River, Texas Gulf Coastal Plain, July 1999-September 2001. 

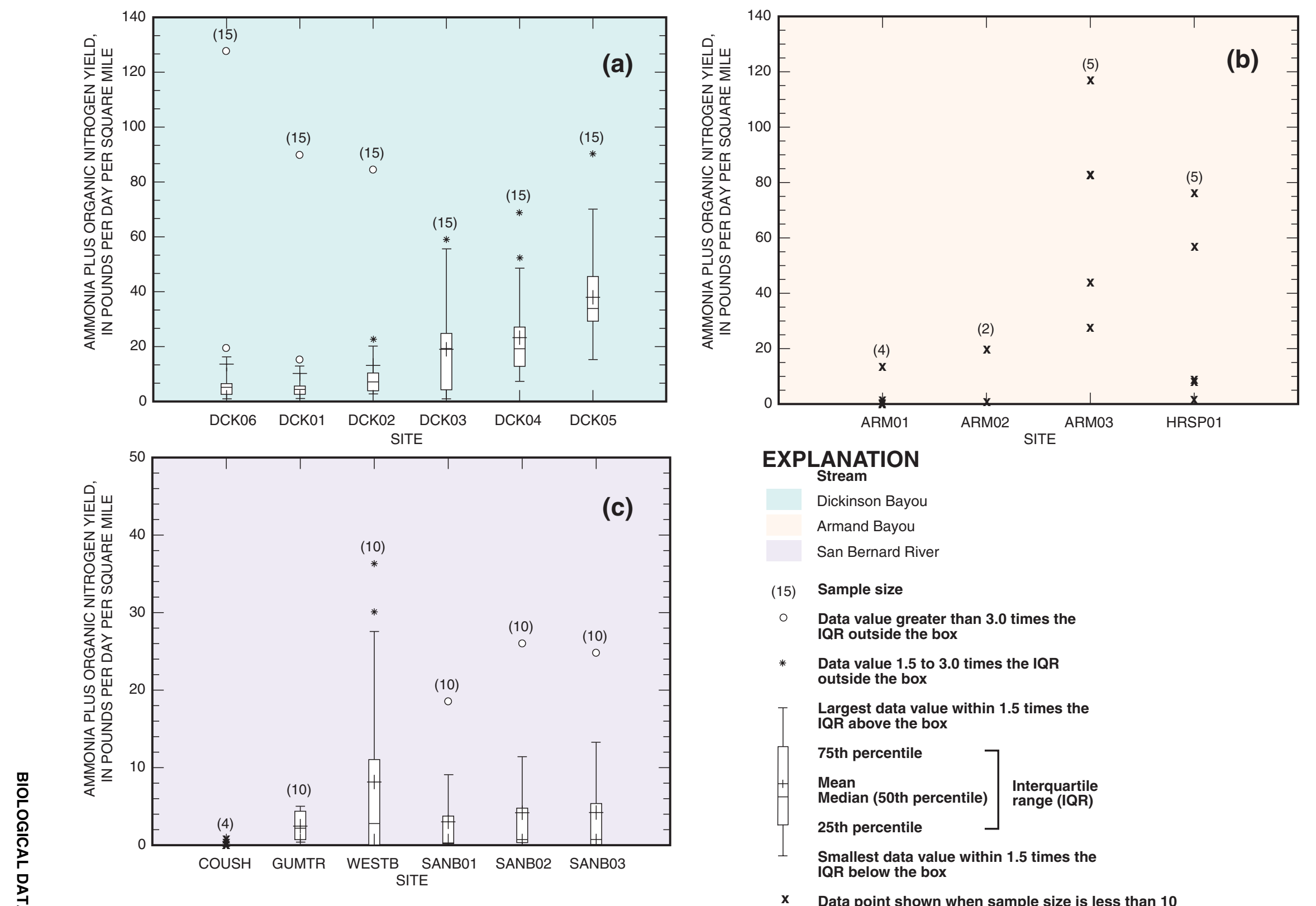

\section{EXPLANATION}

Dickinson Bayou

Armand Bayou

San Bernard River

(15) Sample size

- Data value greater than 3.0 times the IQR outside the box

* Data value 1.5 to 3.0 times the IQR outside the box

Largest data value within 1.5 times the IQR above the box

75th percentile

Mean
Median (50th percentile) \begin{tabular}{l}
$\begin{array}{l}\text { Interquartile } \\
\text { range (IQR) }\end{array}$ \\
\hline
\end{tabular}

25th percentile

Smallest data value within 1.5 times the IQR below the box

$x$ Data point shown when sample size is less than 10

Figure 22. Yields of periodically collected ammonia plus organic nitrogen for selected sites in (a) Dickinson Bayou, (b) Armand Bayou, and (c) the ๘ San Bernard River, Texas Gulf Coastal Plain, July 1999-September 2001. 

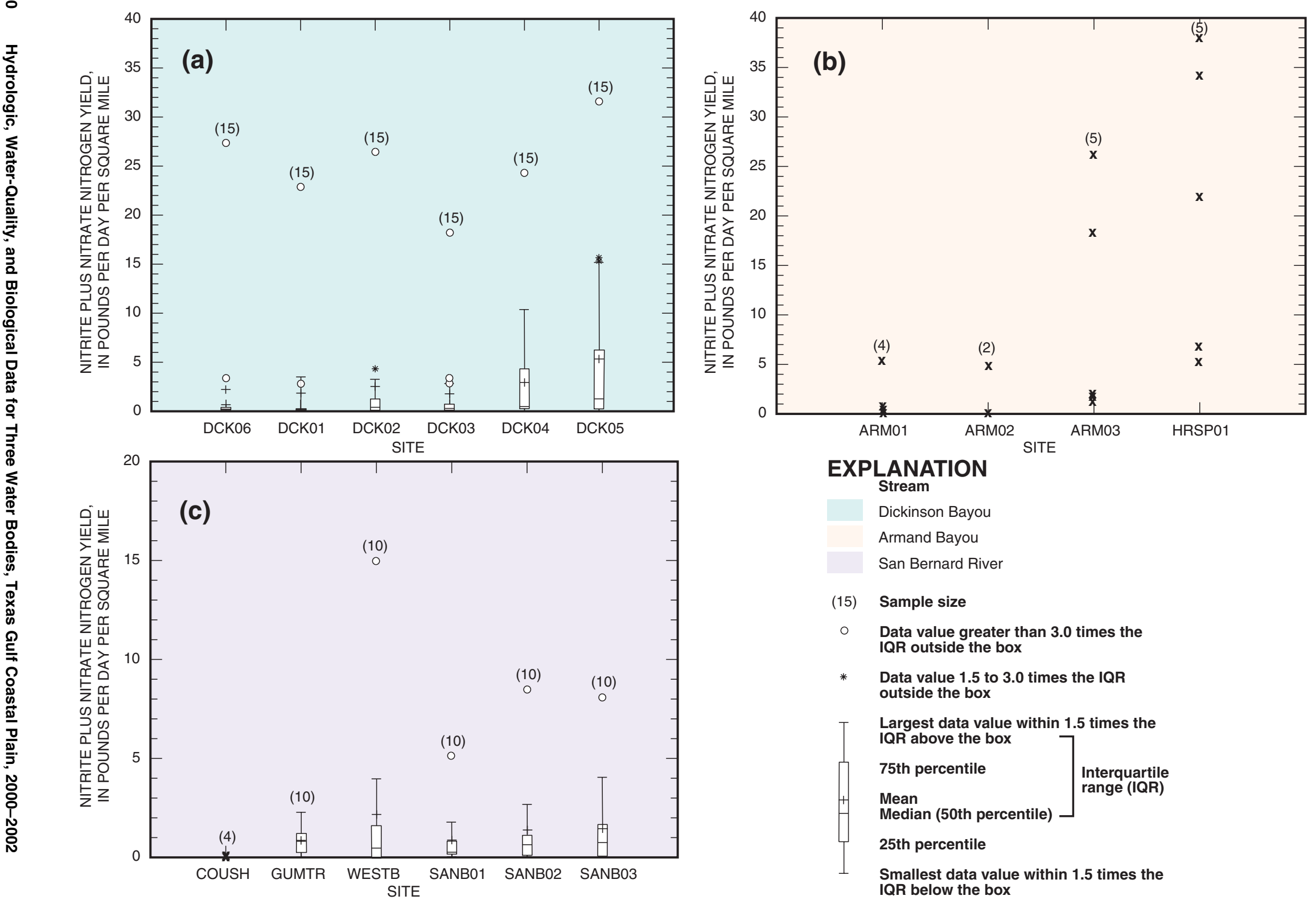

EXPLANATION

\section{Stream}

Dickinson Bayou

Armand Bayou

San Bernard River

(15) Sample size

- Data value greater than 3.0 times the

QR outside the box

* Data value 1.5 to 3.0 times the IQR outside the box

Largest data value within 1.5 times the IQR above the box

75th percentile

Mean

Median (50th percentile) range (IQR)

\section{5th percentile}

Smallest data value within 1.5 times the IQR below the box

$\mathrm{X}$ Data point shown when sample size is less than 10

Figure 23. Yields of periodically collected nitrite plus nitrate nitrogen for selected sites in (a) Dickinson Bayou, (b) Armand Bayou, and (c) the San Bernard River, Texas Gulf Coastal Plain, July 1999-September 2001. 

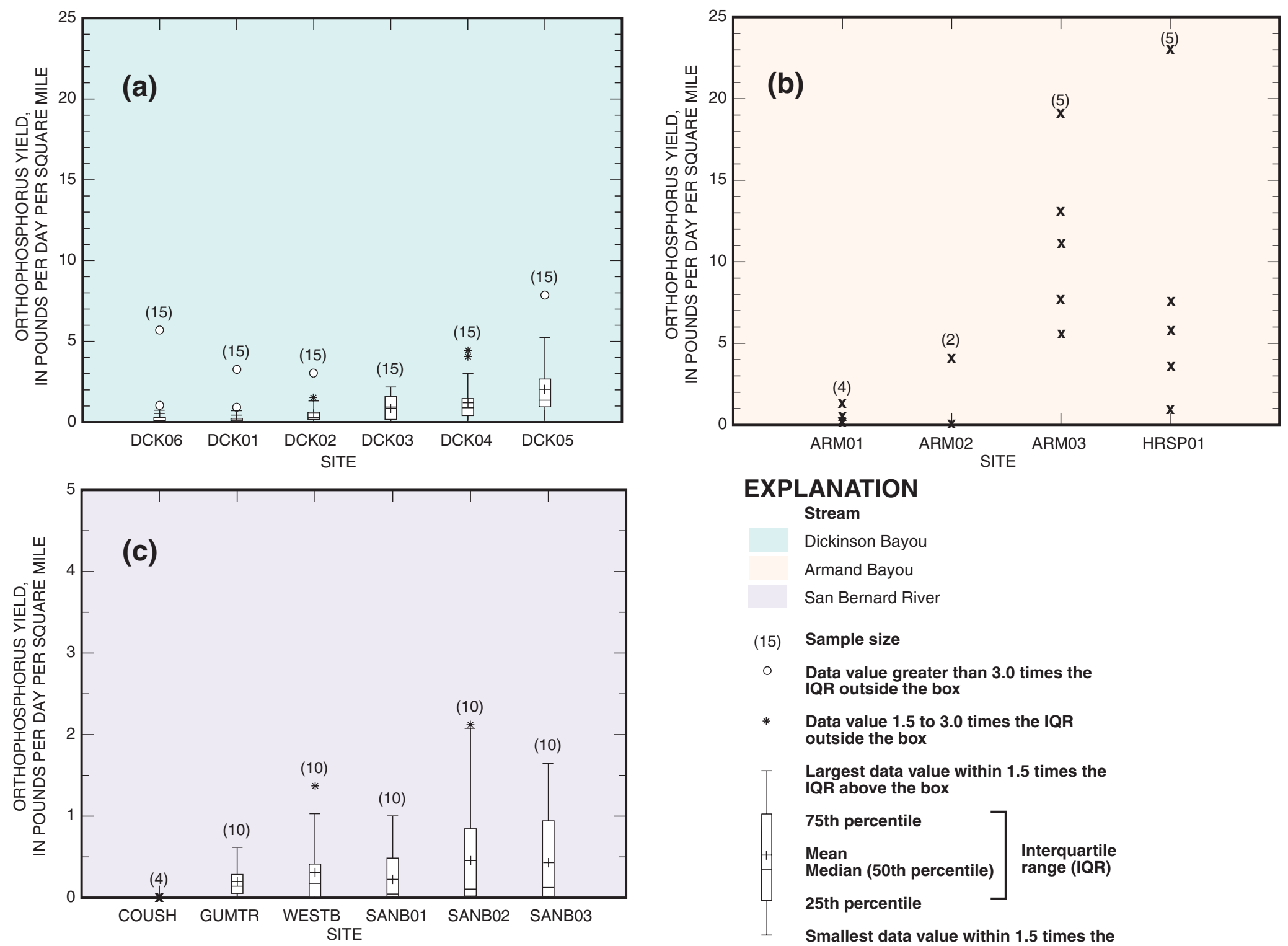

\section{EXPLANATION}

\section{Stream}

Dickinson Bayou

Armand Bayou

San Bernard River

(15) Sample size

○ Data value greater than 3.0 times the QR outside the box

* Data value 1.5 to 3.0 times the IQR outside the box

Largest data value within 1.5 times the QR above the box

\begin{tabular}{l|l} 
75th percentile & \\
Mean & $\begin{array}{l}\text { Interquartile } \\
\text { Median (50th percentile) }\end{array}$
\end{tabular}

25th percentile

Smallest data value within 1.5 times the IQR below the box

$x$ Data point shown when sample size is less than 10

Figure 24. Yields of periodically collected orthophosphorus for selected sites in (a) Dickinson Bayou, (b) Armand Bayou, and (c) the San Bernard 

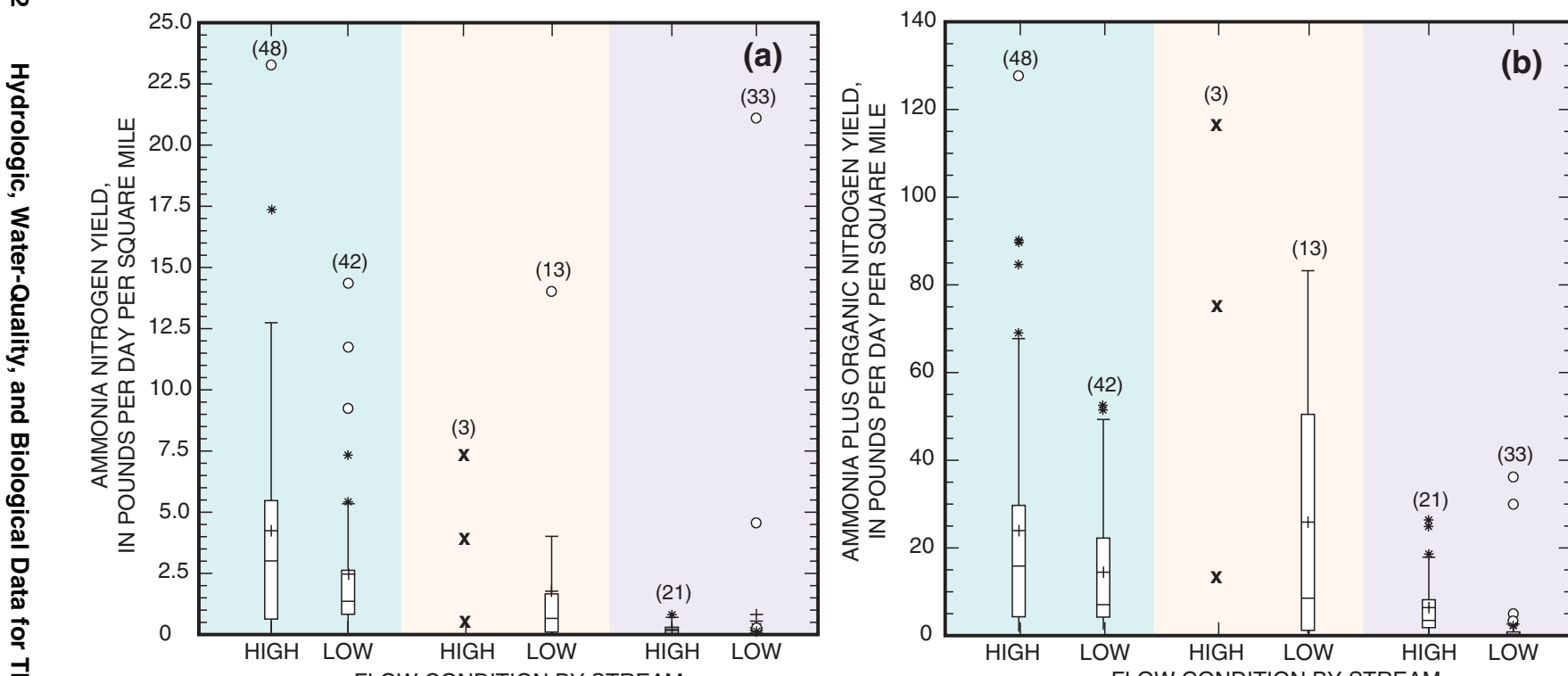

(b)
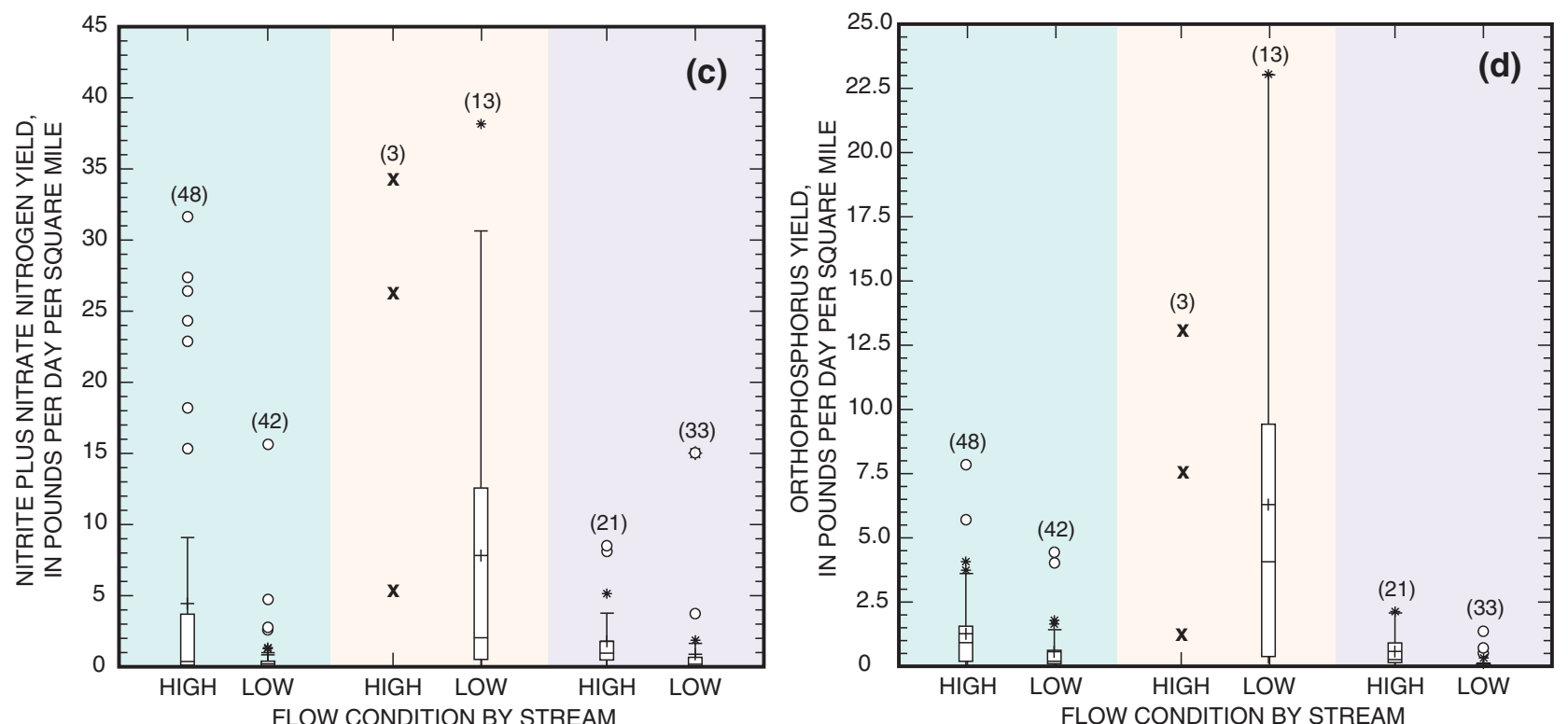

EXPLANATION

Stream

Dickinson Bayou

Armand Bayou

San Bernard River

(13) Sample size

- Data value greater than 3.0 times the IQR outside the box

* Data value 1.5 to 3.0 times the IQR outside the box

Largest data value within 1.5 times the IQR above the box

75th percentile

Mean Interquartile 25th percentile

Smallest data value within 1.5 times the IQR below the box

$x \quad$ Data point shown when sample size is less than 10

Figure 25. Yields of periodically collected (a) ammonia nitrogen, (b) ammonia plus organic nitrogen, (c) nitrite plus nitrate nitrogen, and (d) orthophosphorus during high-flow (above base flow) and low-flow (base flow) conditions in Dickinson Bayou, Armand Bayou, and the San Bernard River, Texas Gulf Coastal Plain, 2000-2002. 
Hogan (2002). The distribution of species collected at each sampling reach in Dickinson Bayou and Armand Bayou are listed in tables 8 and 9 (at end of report), respectively. Examination of fish-survey data (Hogan, 2002, tables 3,2) show that the largest numbers of fish and fish species were collected at the most downstream (brackish) main stem reach in both water bodies (DCK05 and ARM03, respectively).

Fish taxa and individual counts of fish for the San Bernard River are listed in table 10 (at end of report). The fish community structure in the two upstream main stem sites (SANB01 and SANB02) was similar to the community structure in the three tributaries. However, fewer individuals and species were collected at the most downstream main stem site (SANB03), which is opposite to the findings for Dickinson and Armand Bayous.

Fish community metrics were computed for each sampling site (table 11, at end of report). The metrics in the table that are not self-explanatory are Menhinick's richness index, defined as the ratio of the number of species to the square root of the sample size (Menhinick, 1964); and the Shannon-Wiener diversity index, defined as the product of the proportion of the total number of individuals of a given species and $\log _{10}$ of that proportion, quantity summed for all species collected (Brower and Zar, 1977).

\section{Benthic Macroinvertebrate Data}

Benthic macroinvertebrate data might provide better site-specific information about a site or reach than fish community data (Cuffney and others, 1993). Moring (2001) states that fish mobility tends to make determinations of accurate species composition and relative abundance more difficult.

Taxonomic classification of benthic macroinvertebrates and counts of individual taxa for sites in Dickinson and Armand Bayous were presented previously in Hogan (2002, tables 5, 4). These data, together with similar data for the San Bernard River (table 12, at end of report), were used to compute benthic macroinvertebrate community metrics (table 13, at end of report). The metrics in the table that are not selfexplanatory (or previously defined) are Ephemeroptera Plecoptera Trichoptera (EPT) taxa richness, the sum of the number of families within the insect orders of mayflies (Ephemeroptera), stoneflies (Plecoptera), and caddisflies (Trichoptera); Hilsenhoff's biotic index, an index of pollution based on the presence of specific families of aquatic insects (Hilsenhoff, 1987);
Margalef's richness index, a richness index equal to the number of species minus the reciprocal of $\log _{e}$ of the total number of individuals (Ludwig and Reynolds, 1988); Pielou's evenness index, defined as the ShannonWiener diversity index divided by the theoretical maximum of that index if all species in the sample were equally abundant (Menhinick, 1964); and Simpson's heterogeneity index, the probability that two individuals randomly drawn from all individuals collected at a site will be from the same species (Menhinick, 1964).

\section{Habitat Data}

Stream-habitat data collected from reaches in Dickinson and Armand Bayous were presented previously in Hogan (2002, table 6). Stream-habitat data from sites (reaches) in the San Bernard River are listed in table 14 (at end of report). The data in the table that might not be self-explanatory are sinuosity, the ratio of curvilinear reach length to linear reach length; mean channel width, the distance from the left high bank to the right high bank; and mean wetted channel width, the distance between the left edge of the water and the right edge of the water.

\section{SUMMARY}

During July 2000-September 2002, the USGS collected and analyzed site-specific hydrologic, waterquality, and biological data in Dickinson Bayou, Armand Bayou, and the San Bernard River in the Gulf Coastal Plain of Texas. Such data are of interest because segments of the three water bodies are on the State 303(d) list. Hydrologic data collected during the study consisted of precipitation, gage height, and streamflow. Precipitation data were obtained from two rain gages near the three water bodies. Rainfall distributions for the two sites were similar in terms of timing and magnitude, except during June 2001 when Tropical Storm Allison produced much more rainfall in the area of Dickinson and Armand Bayous than in the area of the San Bernard River. Tidally influenced gage height data were collected at continuous monitoring stations in Dickinson and Armand Bayous. The gage height timing and pattern were essentially the same at the two sites, but the magnitudes of tidal fluctuation were different. Streamflow data were computed for the continuous monitoring station in the San Bernard River.

Water temperature, specific conductance, $\mathrm{pH}$, and dissolved oxygen were recorded at 15-minute intervals at one site in each of the three water bodies during 
November 2000-August 2001. Seasonal variations in the water-quality properties for all three sites are typical of those observed at USGS stations along the Texas Gulf Coast. In particular, water temperature and dissolved oxygen are inversely related. Periods of smallest dissolved oxygen concentrations generally occurred in the summer months when water temperatures were highest.

Water-quality monitors were deployed at three depths at the Dickinson Bayou continuous monitoring station. Water temperature was slightly higher near the surface than at mid-depth and near bottom; specific conductance increased with depth; $\mathrm{pH}$ was less variable near the surface; and dissolved oxygen concentrations decreased with depth.

Selected water-quality properties and constituents in each of the three water bodies-principally nutrients, phytoplankton, and indicator bacteria-were collected periodically and measured by laboratory analysis. Samples were collected at six sites in Dickinson Bayou, four sites in Armand Bayou, and six sites in the San Bernard River. The median concentration of ammonia nitrogen was largest in Dickinson Bayou and smallest in the San Bernard River. Median concentrations of ammonia plus organic nitrogen, nitrite plus nitrate nitrogen, and orthophosphorus were largest in Armand Bayou. The median concentration of each of the four nutrients was larger for high-flow samples than for lowflow samples. However, the largest individual concentrations and ranges in concentration occurred in lowflow samples. Although no discernible pattern of seasonality was evident, the largest individual nutrient concentrations and ranges in concentration occurred during spring and summer (growing seasons).

Both median and individual concentrations of chlorophyll-a were largest for Armand Bayou. Median concentrations of pheophyton were similar for all three water bodies. The largest individual pheophyton concentrations were from Armand Bayou. Median concentrations of both chlorophyll-a and pheophytin in lowflow and high-flow samples were less than $5 \mu \mathrm{g} / \mathrm{L}$. However, the largest individual concentrations of each were measured in low-flow samples. Similar to seasonally grouped nutrient concentrations, the largest individual concentrations of chlorophyll-a and pheophytin occurred in spring and summer.

Median densities of fecal coliform bacteria and $E$. coli bacteria were similar in all three water bodies. However, densities of both bacteria varied over wide ranges, particularly in Dickinson Bayou. The largest median and individual bacteria densities were in samples collected during high flow, primarily in fall and winter.

Yields of most nutrients tended to increase with distance downstream, although this characteristic applied less to yields at San Bernard River sites than to Dickinson Bayou and Armand Bayou sites. During both low-flow and high-flow conditions, yields for the San Bernard River were less than yields for Dickinson and Armand Bayous. Based on findings of a previous study in the area, it is likely that some of the differences in the nutrient yields of Dickinson Bayou, Armand Bayou, and the San Bernard River are related to differences in land use in the respective drainage areas.

Fish, benthic macroinvertebrate, and streamhabitat data were collected in each of the three water bodies. For Dickinson and Armand Bayous, the most individuals and species of fish were collected at the most downstream main stem site; for the San Bernard River, the fewest individuals and species were collected at the most downstream main stem site.

\section{REFERENCES}

Bower, J.E., and Zar, J.H., 1977, Field and laboratory methods for general ecology: Dubuque, Iowa, W.C. Brown, $193 \mathrm{p}$.

Coplin, L.S., and Lanning-Rush, Jennifer, 2002, Water-level altitudes 2002 and water-level changes in the Chicot, Evangeline, and Jasper aquifers and compaction 19732001 in the Chicot and Evangeline aquifers, HoustonGalveston Region, Texas: U.S. Geological Survey Open-File Report 02-134, 15 sheets, accessed March 6, 2003, at URL http://water.usgs.gov/pubs/of/ofr02-134/

Cuffney, T.F., Gurtz, M.E., and Meador, M.R., 1993, Methods for collecting benthic invertebrate samples as part of the National Water-Quality Assessment Program: U.S. Geological Survey Open-File Report 93-406, 66 p.

East, J.W., Paul, E.M., and Porter, S.D., 1998, Nutrient loading and selected water-quality and biological characteristics of Dickinson Bayou near Houston, Texas, 1995-97: U.S. Geological Survey Water-Resources Investigations Report 98-4012, 50 p.

Hilsenhoff, W.L., 1987, An improved biotic index of stream pollution: Great Lakes Entomology, v. 20, p. 31-39.

Hogan, J.L., 2002, Fish, benthic-macroinvertebrate, and stream-habitat data from two estuaries near Galveston Bay, Texas, 2000-2001: U.S. Geological Survey OpenFile Report 02-024, 16 p. 
Linam, G.W., and Kleinsasser, L.J., 1998, Classification of Texas freshwater fishes into trophic and tolerance groups: Texas Parks and Wildlife Department, River Studies Report 14, 6 p., accessed November 5, 2003, at URL http://water.usgs.gov/pubs/wri/wri014010/

Ludwig, J.A., and Reynolds, J.F., 1988, Statistical ecologyA primer of methods and computing: New York, Wiley, $337 \mathrm{p}$.

Menhinick, E.F., 1964, A comparison of some speciesindividuals diversity indices applied to samples of field insects: Ecology, v. 45, p. 859-861.

Moring, J.B., 2001, Influence of stream habitat and land use on benthic macroinvertebrate indicators of stream quality of selected above-tidal streams in the HoustonGalveston Area Council service area, Texas, 1997-98: U.S. Geological Survey Water-Resources Investigations Report 01-4010, 22 p., accessed November 5, 2003, at URL http://water.usgs.gov/pubs/wri/wri014010/

National Atmospheric Deposition Program (NRSP-3)/ National Trends Network, 2003, Monthly data for siteTX10 (Attwater Prairie Chicken National Wildlife Refuge): NADP Program Office, Illinois State Water Survey, accessed March 6, 2003, at URL http://nadp.sws.uiuc.edu/nadpdata/ monthlyRequest.asp? site $=\mathrm{tx} 10$

National Weather Service, 2003, National Weather Service forecast office, NWS HGX Office/League City climate data: accessed March 6, 2003, at URL: http://www.srh.noaa.gov/hgx/climate/hgx.htm

Parsons Engineering Science, Inc., 2000, Report for water quality and biological characterization of Armand Bayou, Houston, Texas: [Prepared for] Texas General Land Office GLO contract no. 99-123R and Texas Natural Resource Conservation Commission, 87 p.

Rantz, S.E., and others, 1982, Measurement and computation of streamflow-Volumes 1 and 2: U.S. Geological Survey Water-Supply Paper 2175, $631 \mathrm{p}$.

Simpson, Michael, 2001, Discharge measurements using a broad-band acoustic Doppler current profiler: U.S. Geological Survey Open-File Report 01-01, 123 p.

Texas Commission on Environmental Quality, 2002, Draft 2002 Texas 303(d) list (October 1, 2002): accessed August 27, 2003, at URL http://www.tnrcc.state.tx.us/water/quality/02_twqmar/ 02_categories/02_303d.pdf

2003, Surface water assessment methodology: accessed June 2, 2003, at URL http://www.tnrcc.state.tx.us/water/quality/02_twqmar/ 02_305b/02_program_summary/12-swass.pdf

Terrio, P.J., 1995, Water-quality assessment of the Upper Illinois River Basin in Illinois, Indiana, and Wisconsin-Nutrients, dissolved oxygen, and fecal indicator bacteria in surface water, April 1987 through August 1990: U.S. Geological Survey Water-Resources Investigations Report 95-4005, 79 p.

Texas Natural Resource Conservation Commission, 1998, State of Texas 1998 Clean Water Act section 303(d) list (06/26/98): accessed August 27, 2003, at URL http://www.tnrcc.state.tx.us/water/quality/98_303D.pdf

1999, Surface water quality monitoring procedures manual: Texas Natural Resource Conservation Commission, Water Quality Division, GI-252 [variously paged].

Texas Natural Resources Information System, 2003, Digital elevation models_-Data availability and downloads: accessed April 3, 2003, at URL http://www.tnris.state.tx.us/stratmap/dem.htm

Texas Parks and Wildlife, 1997, GEMS-Armand Bayou Coastal Preserve \& Nature Center: accessed April 10, 2000, at URL http://www.tpwd.state.tx.us/conserve/txgems/ armandba/armandba.htm

Texas Water Commission, 1992, The State of Texas water quality inventory (11th ed.): Austin, Tex., LP 92-16, $671 \mathrm{p}$.

U.S. Census Bureau, 2003, United States census 2000: accessed April 1, 2003, at URL http://www.census.gov/main/www/cen2000.html

U.S. Geological Survey, 1997-present, National field manual for the collection of water-quality data: U.S. Geological Survey Techniques of Water-Resources Investigations, book 9, chaps. A1-A7, accessed April 1, 2003, at URL http://water.usgs.gov/owq/FieldManual/

Wagner, R.J., Mattraw, H.C., Ritz, G.F., and Smith, B.A., 2000, Guidelines and standard procedures for continuous water-quality monitoring-Site selection, field operation, calibration, record computation, and reporting: U.S. Geological Survey Water-Resources Investigations Report 00-4252, 53 p. 
Table 4. Periodically collected water-quality properties and constituents at six sites in Dickinson Bayou, July 2000August 2001

[Data provided by Galveston County Health District and Texas Commission on Environmental Quality; numbers in parentheses below property and constituent names are USGS National Water Quality Laboratory parameter codes]

0807764230 Dickinson Bayou at Ginger Rd, nr Alvin, TX

WATER-QUALITY DATA, WATER YEAR OCTOBER 1999 TO SEPTEMBER 2000

\begin{tabular}{|c|c|c|c|c|c|c|c|c|c|c|c|c|c|}
\hline & & $\begin{array}{c}\text { DIS- } \\
\text { CHARGE } \\
\text { INST. }\end{array}$ & & $\begin{array}{l}\text { SPE- } \\
\text { CIFIC }\end{array}$ & & $\begin{array}{c}\text { PH } \\
\text { WATER } \\
\text { WHOLE }\end{array}$ & $\begin{array}{l}\text { COLI- } \\
\text { FORM, } \\
\text { FECAL, }\end{array}$ & $\mathrm{E}$ & $\begin{array}{l}\text { ENTERO- } \\
\text { COCCI, }\end{array}$ & $\begin{array}{l}\text { NITRO- } \\
\text { GEN, }\end{array}$ & $\begin{array}{l}\text { NITRO- } \\
\text { GEN, AM- } \\
\text { MONIA + }\end{array}$ & $\begin{array}{l}\text { NITRO- } \\
\text { GEN, }\end{array}$ & $\begin{array}{c}\text { ORTHO- } \\
\text { PHOS- } \\
\text { PHATE, }\end{array}$ \\
\hline at & ime & $\begin{array}{l}\text { CUBIC } \\
\text { FEET } \\
\text { PER } \\
\text { SECOND } \\
(00061)\end{array}$ & $\begin{array}{l}\text { TEMPER- } \\
\text { ATURE } \\
\text { WATER } \\
\text { (DEG C) } \\
(00010)\end{array}$ & $\begin{array}{l}\text { CON- } \\
\text { DUCT- } \\
\text { ANCE } \\
\text { (US/CM) } \\
(00095)\end{array}$ & $\begin{array}{c}\text { OXYGEN, } \\
\text { DIS- } \\
\text { SOLVED } \\
\text { (MG/L) } \\
(00300)\end{array}$ & $\begin{array}{l}\text { FIELD } \\
\text { (STAND- } \\
\text { ARD } \\
\text { UNITS) } \\
(00400)\end{array}$ & $\begin{array}{l}0.7 \\
\text { UM-MF } \\
\text { (COLS./ } \\
100 \mathrm{ML}) \\
(31625)\end{array}$ & $\begin{array}{l}\text { MTEC MF } \\
\text { WATER } \\
\text { (COL/ } \\
100 \mathrm{ML}) \\
(31633)\end{array}$ & $\begin{array}{l}\text { ME MF, } \\
\text { WATER } \\
\text { (COL/ } \\
100 \mathrm{ML}) \\
(31649)\end{array}$ & $\begin{array}{c}\text { AMMONIA } \\
\text { TOTAL } \\
\text { (MG/L } \\
\text { AS N) } \\
(00610)\end{array}$ & $\begin{array}{c}\text { ORGANIC } \\
\text { TOTAL } \\
\text { (MG/L } \\
\text { AS N) } \\
(00625)\end{array}$ & $\begin{array}{c}\text { NO2+NO3 } \\
\text { TOTAL } \\
(\mathrm{MG} / \mathrm{L} \\
\text { AS N) } \\
(00630)\end{array}$ & $\begin{array}{c}\text { DIS- } \\
\text { SOLVED } \\
\text { (MG/L } \\
\text { AS P) } \\
(00671)\end{array}$ \\
\hline
\end{tabular}

\begin{tabular}{|c|c|c|c|c|c|c|c|c|c|c|c|c|c|}
\hline JUL & & & & & & & & & & & & & \\
\hline$\underset{\text { AUG }}{10} \ldots$ & 1634 & 55 & -- & -- & -- & -- & 130 & 130 & 174 & .01 & .13 & .63 & .01 \\
\hline $17 \ldots$ & 1035 & -42 & 28.1 & 680 & 2.9 & 7.6 & 80 & 80 & 142 & .06 & .17 & .84 & .01 \\
\hline $\begin{array}{l}\mathrm{SEP} \\
12 \ldots\end{array}$ & 1042 & 29 & 28.0 & 1100 & 3.3 & 7.3 & 130 & 130 & 418 & .01 & .20 & 1.02 & .01 \\
\hline
\end{tabular}

\begin{tabular}{|c|c|c|}
\hline & CHLOR-A & \\
\hline & $\begin{array}{c}\text { PHYTO- } \\
\text { PLANK- } \\
\text { TON }\end{array}$ & $\begin{array}{c}\text { PHEO- } \\
\text { PHYTIN } \\
\text { A, }\end{array}$ \\
\hline & CHROMO & РНҮTO- \\
\hline Date & FLUOROM & PHYTON \\
\hline & (UG/L) & (UG/L) \\
\hline & $(70953)$ & $(62360)$ \\
\hline JUL & & \\
\hline 10. & $<1.0$ & $<1.0$ \\
\hline AUG & & \\
\hline $17 .$. & $<1.0$ & 1.89 \\
\hline SEP & & \\
\hline 12. & $<1.0$ & $<1.0$ \\
\hline
\end{tabular}


Table 4. Periodically collected water-quality properties and constituents at six sites in Dickinson Bayou, July 2000August 2001-Continued

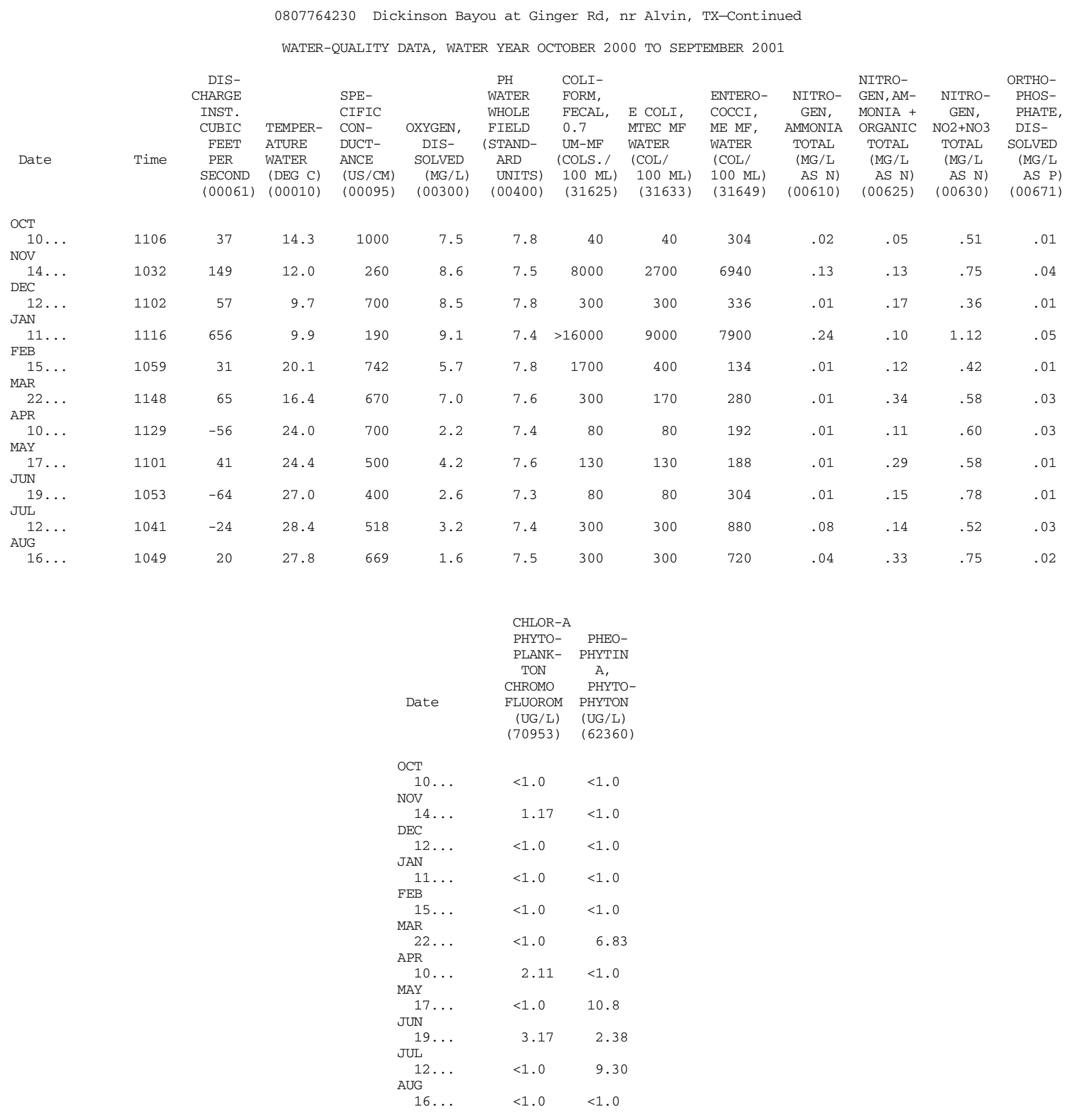

Remark codes used in this table:

<-- Less than

$>$-- Greater than 
Table 4. Periodically collected water-quality properties and constituents at six sites in Dickinson Bayou, July 2000August 2001-Continued

8077643 Dickinson Bayou at Cemetary Rd nr Dickinson, TX

WATER-QUALITY DATA, WATER YEAR OCTOBER 1999 TO SEPTEMBER 2000

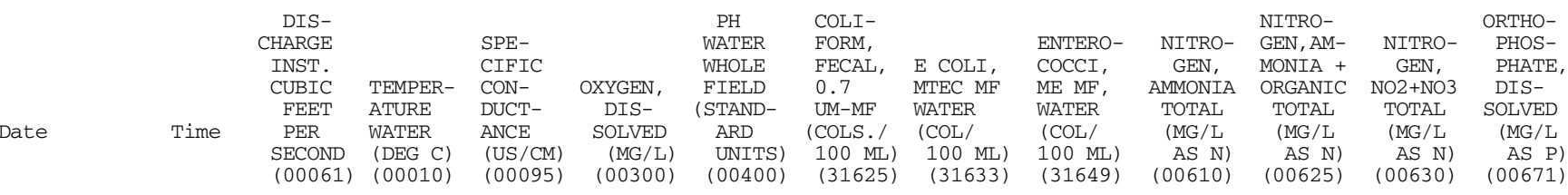

\begin{tabular}{|c|c|c|c|c|c|c|c|c|c|c|c|c|c|}
\hline JUL & & & & & & & & & & & & & \\
\hline $\begin{array}{c}10 \ldots \\
\text { AUG }\end{array}$ & 1557 & 55 & -- & -- & -- & -- & 40 & 40 & 16 & .01 & .10 & .66 & .01 \\
\hline $17 \ldots$ & 0753 & -44 & 28.4 & 3800 & 4.7 & 7.5 & 80 & 80 & 8 & .01 & .07 & .90 & .03 \\
\hline SEP & & & & & & & & & & & & & \\
\hline $12 \ldots$ & 0748 & 29 & 28.1 & 3500 & 0.3 & 7.1 & 220 & 220 & 228 & .01 & .29 & 1.21 & .04 \\
\hline
\end{tabular}

$\begin{array}{ccc} & \begin{array}{c}\text { CHLOR-A } \\ \text { PHYTO- } \\ \text { PLANK- } \\ \text { TON } \\ \text { CHROMO }\end{array} & \begin{array}{c}\text { PHEO- } \\ \text { PHYTIN } \\ \text { A, } \\ \text { PHYTO- }\end{array} \\ \begin{array}{c}\text { FLUOROM } \\ \text { (UG/L) } \\ (70953)\end{array} & \begin{array}{c}\text { PHYTON } \\ (\text { UG/L) } \\ (62360)\end{array} \\ \begin{array}{c}\text { JUL } \\ 10 \ldots \\ \text { AUG } \\ \text { 17 } \ldots\end{array} & <1.0 & <1.0 \\ \begin{array}{c}\text { SEP } \\ 12 \ldots\end{array} & 55.3 & 7.14 \\ & 5.11 & 3.51\end{array}$


Table 4. Periodically collected water-quality properties and constituents at six sites in Dickinson Bayou, July 2000August 2001-Continued

08077643 Dickinson Bayou at Cemetary Rd nr Dickinson, TX-Continued

WATER-QUALITY DATA, WATER YEAR OCTOBER 2000 TO SEPTEMBER 2001

\begin{tabular}{|c|c|c|c|c|c|c|c|c|c|c|c|c|c|}
\hline & & $\begin{array}{c}\text { DIS- } \\
\text { CHARGE } \\
\text { INST. }\end{array}$ & & $\begin{array}{l}\text { SPE- } \\
\text { CIFIC }\end{array}$ & & $\begin{array}{c}\text { PH } \\
\text { WATER } \\
\text { WHOLE }\end{array}$ & $\begin{array}{l}\text { COLI- } \\
\text { FORM, } \\
\text { FECAL, }\end{array}$ & $\mathrm{E} \mathrm{COL}$ & $\begin{array}{l}\text { ENTERO- } \\
\text { COCCI, }\end{array}$ & $\begin{array}{c}\text { NITRO- } \\
\text { GEN }\end{array}$ & $\begin{array}{l}\text { NITRO- } \\
\text { GEN, AM- } \\
\text { MONIA + }\end{array}$ & $\begin{array}{c}\text { NITRO- } \\
\text { GEN, }\end{array}$ & $\begin{array}{c}\text { ORTHO- } \\
\text { PHOS- } \\
\text { PHATE, }\end{array}$ \\
\hline t & Time & $\begin{array}{c}\text { CUBIC } \\
\text { FEET } \\
\text { PER } \\
\text { SECOND } \\
(00061)\end{array}$ & $\begin{array}{l}\text { TEMPER- } \\
\text { ATURE } \\
\text { WATER } \\
(\text { DEG C) } \\
(00010)\end{array}$ & $\begin{array}{l}\text { CON- } \\
\text { DUCT- } \\
\text { ANCE } \\
(\text { US /CM) } \\
(00095)\end{array}$ & $\begin{array}{c}\text { OXYGEN, } \\
\text { DIS- } \\
\text { SOLVED } \\
(\text { MG/L) } \\
(00300)\end{array}$ & $\begin{array}{l}\text { FIELD } \\
\text { (STAND- } \\
\text { ARD } \\
\text { UNITS) } \\
(00400)\end{array}$ & $\begin{array}{l}0.7 \\
\text { UM-MF } \\
\text { (COLS./ } \\
100 \text { ML) } \\
(31625)\end{array}$ & $\begin{array}{l}\text { MTEC MF } \\
\text { WATER } \\
\text { (COL/ } \\
100 \mathrm{ML)} \\
(31633)\end{array}$ & $\begin{array}{l}\text { ME MF, } \\
\text { WATER } \\
\text { (COL/ } \\
100 \mathrm{ML)} \\
(31649)\end{array}$ & $\begin{array}{c}\text { AMMONIA } \\
\text { TOTAL } \\
\text { (MG/L } \\
\text { AS N) } \\
(00610)\end{array}$ & $\begin{array}{c}\text { ORGANIC } \\
\text { TOTAL } \\
\text { (MG/L } \\
\text { AS N) } \\
(00625)\end{array}$ & $\begin{array}{c}\mathrm{NO} 2+\mathrm{NO} 3 \\
\text { TOTAL } \\
(\mathrm{MG} / \mathrm{L} \\
\text { AS N) } \\
(00630)\end{array}$ & $\begin{array}{c}\text { DIS- } \\
\text { SOLVED } \\
(\mathrm{MG} / \mathrm{L} \\
\text { AS P) } \\
(00671)\end{array}$ \\
\hline
\end{tabular}

\begin{tabular}{|c|c|c|c|c|c|c|c|c|c|c|c|c|c|}
\hline \multicolumn{14}{|l|}{ OCT } \\
\hline $10 \ldots$ & 0802 & 37 & 17.6 & 4700 & 1.6 & 7.1 & 20 & 20 & 300 & .04 & .05 & .82 & .04 \\
\hline \multicolumn{14}{|l|}{ NOV } \\
\hline $14 \ldots$ & 0705 & 149 & 12.8 & 260 & 7.9 & 7.4 & 9000 & 5000 & 11800 & .15 & .13 & .83 & .05 \\
\hline \multicolumn{14}{|l|}{$\mathrm{DEC}$} \\
\hline $12 \ldots$ & 0757 & 57 & 12.4 & 800 & 5.0 & 7.6 & 170 & 170 & 118 & .01 & .19 & .46 & .02 \\
\hline \multicolumn{14}{|l|}{ JAN } \\
\hline $11 \ldots$ & 0752 & 656 & 9.9 & 200 & 9.0 & 7.4 & $>16000$ & $>16000$ & 4000 & .28 & .10 & 1.10 & .04 \\
\hline \multicolumn{14}{|l|}{$\mathrm{FEB}$} \\
\hline $15 \ldots$ & 0755 & 30 & 17.8 & 800 & 5.9 & 7.7 & 300 & 300 & 166 & .01 & .05 & .36 & .01 \\
\hline \multicolumn{14}{|l|}{ MAR } \\
\hline $22 \ldots$ & 0739 & 65 & 15.7 & 680 & 6.7 & 7.5 & 230 & 230 & 186 & .01 & .36 & .70 & .03 \\
\hline \multicolumn{14}{|l|}{ APR } \\
\hline $10 \ldots$ & 0812 & -56 & 24.4 & 736 & 1.7 & 7.4 & 70 & 70 & 118 & .01 & .17 & .72 & .04 \\
\hline \multicolumn{14}{|l|}{ MAY } \\
\hline $17 \ldots$ & 0755 & 41 & 24.5 & 500 & 3.6 & 7.5 & 130 & 130 & 180 & .01 & .23 & .68 & .01 \\
\hline \multicolumn{14}{|l|}{ JUN } \\
\hline $19 \ldots$ & 0759 & -64 & 27.7 & 400 & 1.2 & 7.1 & 500 & 500 & 62 & .02 & .25 & .85 & .02 \\
\hline \multicolumn{14}{|l|}{ JUL } \\
\hline $12 \ldots$ & 0803 & -24 & 28.7 & 566 & 2.0 & 7.2 & 230 & 230 & 240 & .12 & .14 & .87 & .03 \\
\hline \multicolumn{14}{|l|}{ AUG } \\
\hline $16 \ldots$ & 0733 & 20 & 28.8 & 5140 & 1.3 & 7.2 & 70 & 70 & 70 & .02 & .22 & .60 & .04 \\
\hline
\end{tabular}

$\begin{array}{ccc} & \text { CHLOR-A } & \\ & \text { PHYTO- } & \text { PHEO- } \\ \text { PLANK- } & \text { PHYTIN } \\ & \text { TON } & \text { A, } \\ & \text { CHROMO } & \text { PHYTO- } \\ \text { Date } & \text { FLUOROM } & \text { PHYTON } \\ & \text { (UG/L) } & \text { (UG/L) } \\ & \text { (70953) } & (62360)\end{array}$

\begin{tabular}{|c|c|c|}
\hline $\mathrm{OCT}$ & & \\
\hline $10 \ldots$ & $<1.0$ & 3.78 \\
\hline NOV & & \\
\hline $14 \ldots$ & $<1.0$ & $<1.0$ \\
\hline DEC & & \\
\hline $12 \ldots$ & 2.74 & $<1.0$ \\
\hline JAN & & \\
\hline $11 \ldots$ & 6.42 & 7.05 \\
\hline FEB & & \\
\hline $15 \ldots$ & $<1.0$ & $<1.0$ \\
\hline MAR & & \\
\hline $22 \ldots$ & $<1.0$ & $<1.0$ \\
\hline APR & & \\
\hline $10 \ldots$ & $<1.0$ & $<1.0$ \\
\hline MAY & & \\
\hline $17 \ldots$ & 8.46 & 4.57 \\
\hline JUN & & \\
\hline $19 \ldots$ & 3.23 & $<1.0$ \\
\hline JUL & & \\
\hline $12 \ldots$ & 10.2 & $<1.0$ \\
\hline AUG & & \\
\hline $16 \ldots$ & 2.00 & 2.00 \\
\hline
\end{tabular}

Remark codes used in this table:

$<--$ Less than

$>$-- Greater than 
Table 4. Periodically collected water-quality properties and constituents at six sites in Dickinson Bayou, July 2000August 2001-Continued

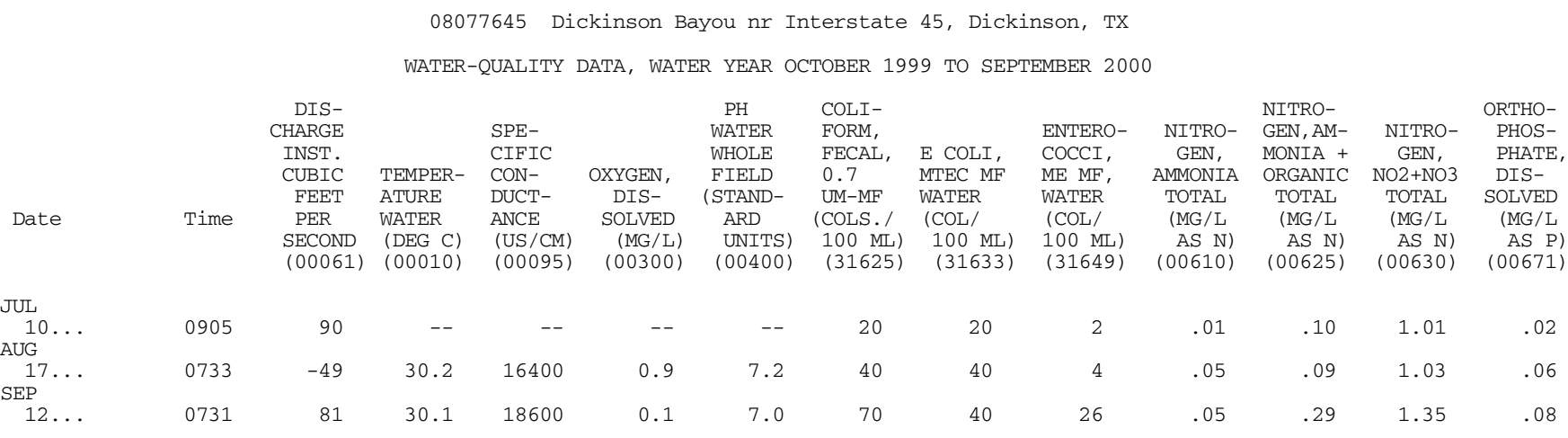

\begin{tabular}{|c|c|c|}
\hline Date & $\begin{array}{c}\text { CHLOR-A } \\
\text { PHYTO- } \\
\text { PLANK- } \\
\text { TON } \\
\text { CHROMO } \\
\text { FLUOROM } \\
\text { (UG/L) } \\
(70953)\end{array}$ & $\begin{array}{c}\text { PHEO- } \\
\text { PHYTIN } \\
\text { A, } \\
\text { PHYTO- } \\
\text { PHYTON } \\
\text { (UG/L) } \\
(62360)\end{array}$ \\
\hline $\begin{array}{l}\text { JUL } \\
10 \ldots \\
\text { AUG }\end{array}$ & 3.20 & 14.0 \\
\hline $\begin{array}{l}17 \ldots \\
\operatorname{SEP} \\
12 \ldots\end{array}$ & 17.3 & $\begin{array}{l}<1.0 \\
5.06\end{array}$ \\
\hline
\end{tabular}


Table 4. Periodically collected water-quality properties and constituents at six sites in Dickinson Bayou, July 2000August 2001-Continued

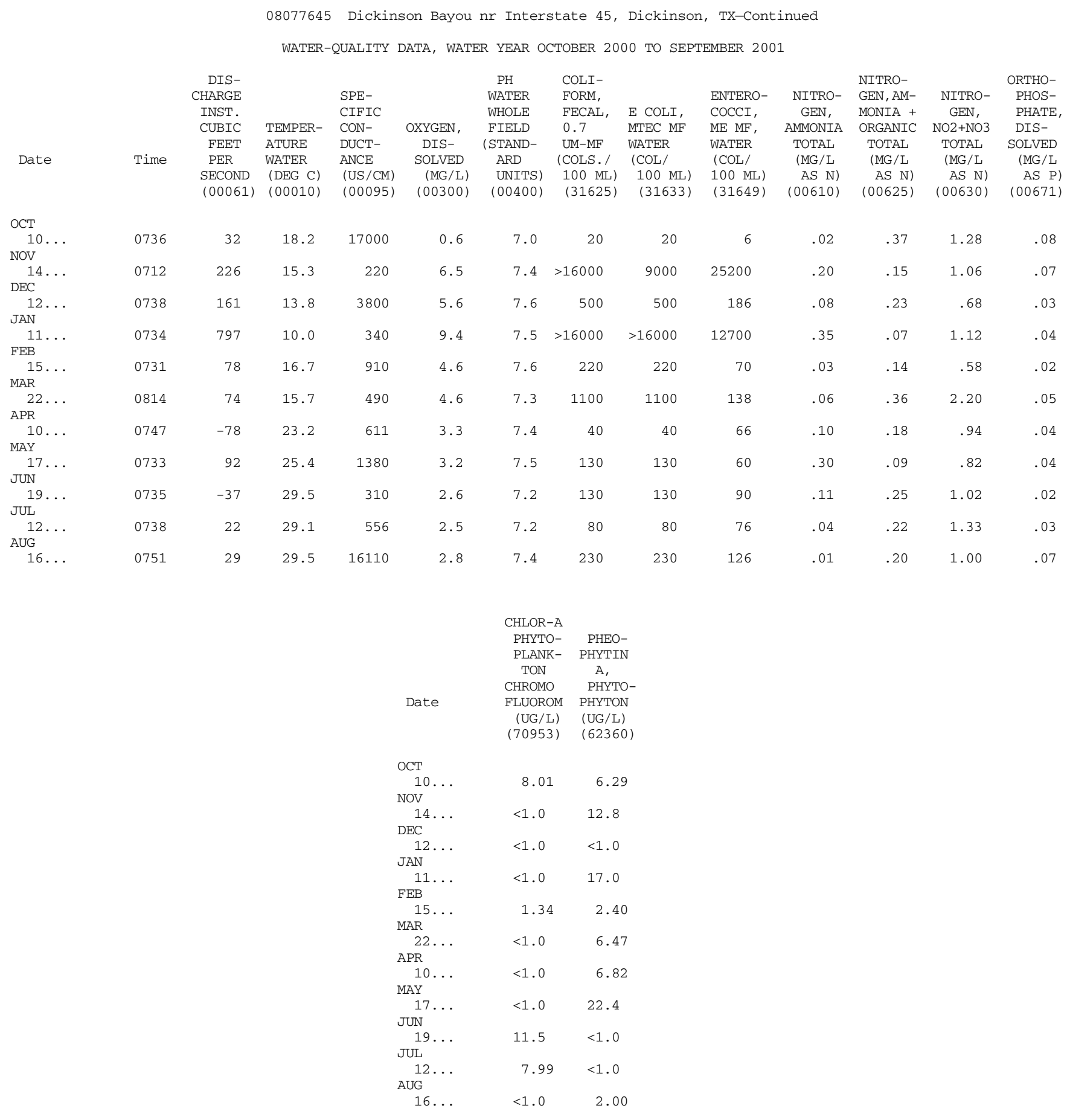

Remark codes used in this table:

<-- Less than

$>$-- Greater than 
Table 4. Periodically collected water-quality properties and constituents at six sites in Dickinson Bayou, July 2000August 2001-Continued

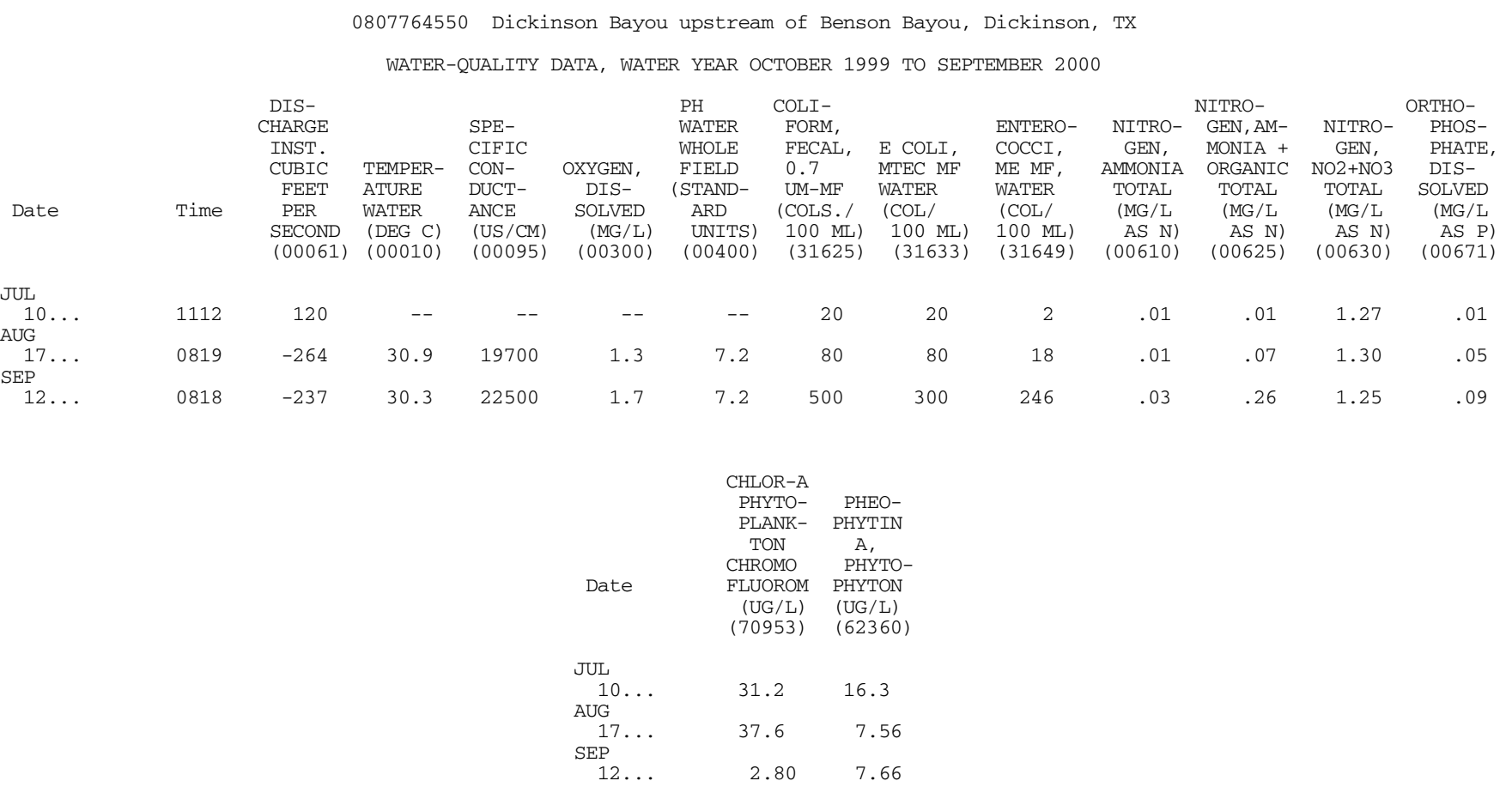


Table 4. Periodically collected water-quality properties and constituents at six sites in Dickinson Bayou, July 2000August 2001-Continued

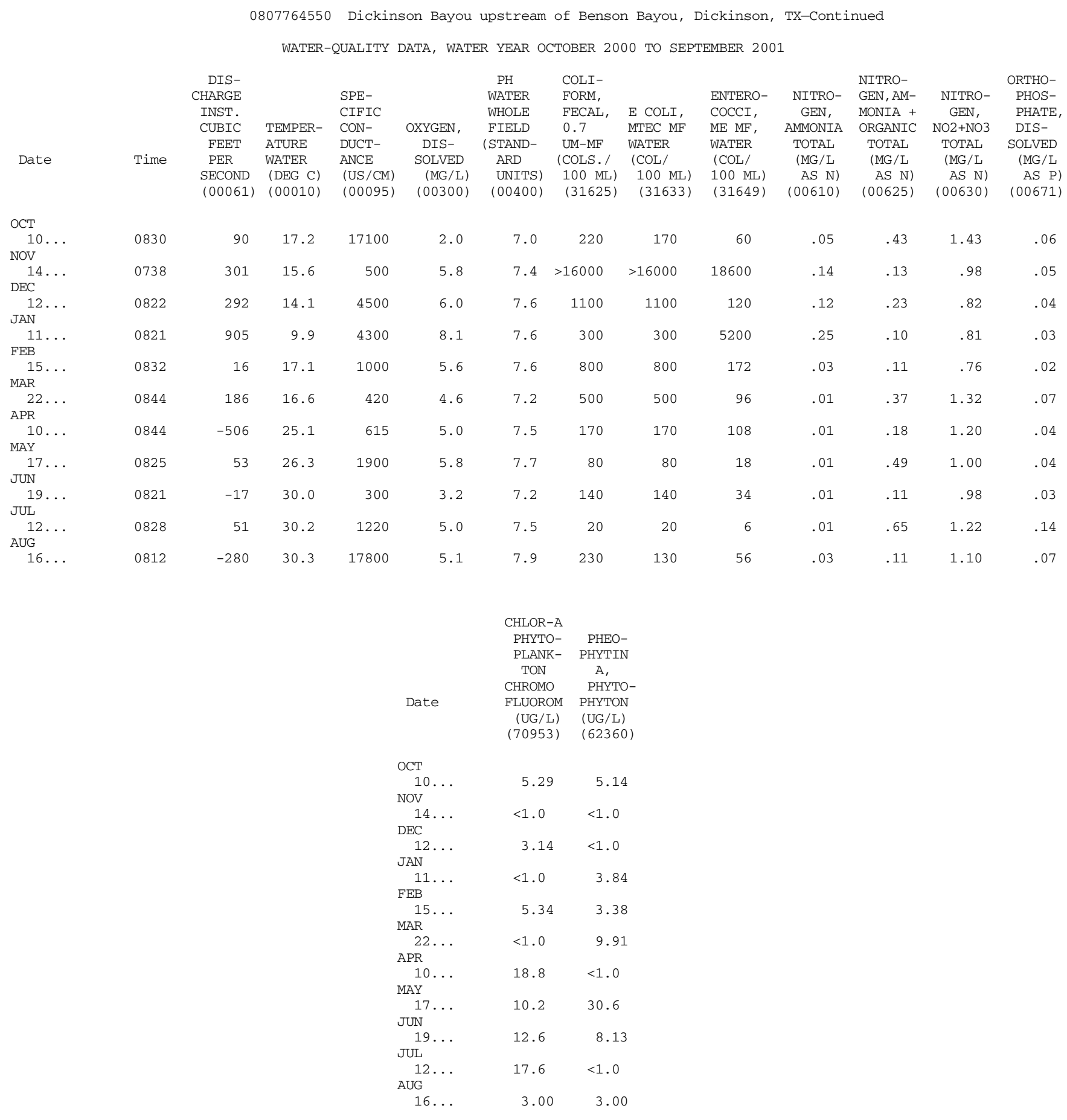

Remark codes used in this table:

< -- Less than

$>$-- Greater than 
Table 4. Periodically collected water-quality properties and constituents at six sites in Dickinson Bayou, July 2000August 2001-Continued

08077647 Dickinson Bayou at State Hwy 3, Dickinson, TX

WATER-QUALITY DATA, WATER YEAR OCTOBER 1999 TO SEPTEMBER 2000

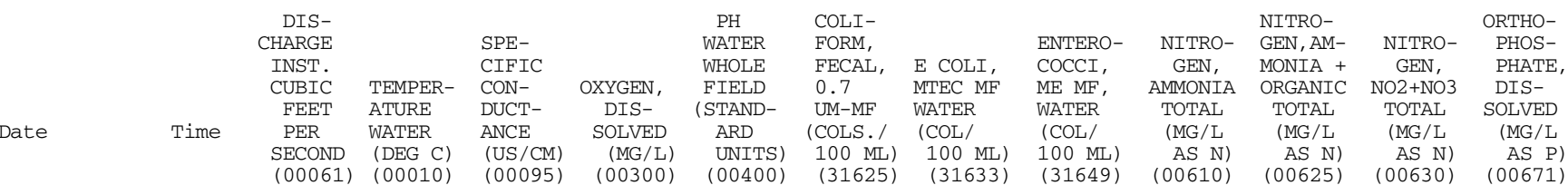

\begin{tabular}{|c|c|c|c|c|c|c|c|c|c|c|c|c|c|}
\hline \\
\hline$\underset{\text { AUG }}{10 \ldots}$ & 1237 & 219 & -- & -- & -- & -- & 80 & 80 & 18 & .01 & .02 & 1.24 & .01 \\
\hline $17 \ldots$ & 0836 & -307 & 31.1 & 22600 & 1.5 & 7.4 & 70 & 70 & 38 & .02 & .19 & 1.22 & .04 \\
\hline SEP & & & & & & & & & & & & & \\
\hline $12 \ldots$ & 0836 & -183 & 30.0 & 24700 & 1.2 & 7.1 & 800 & 220 & 226 & .01 & .32 & 1.56 & .11 \\
\hline
\end{tabular}

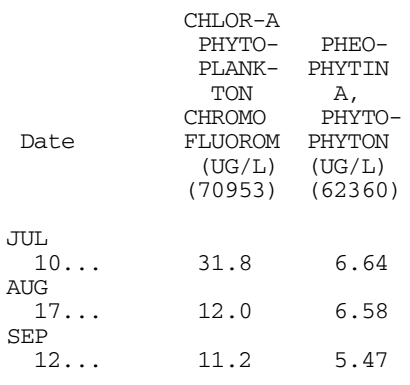


Table 4. Periodically collected water-quality properties and constituents at six sites in Dickinson Bayou, July 2000August 2001-Continued

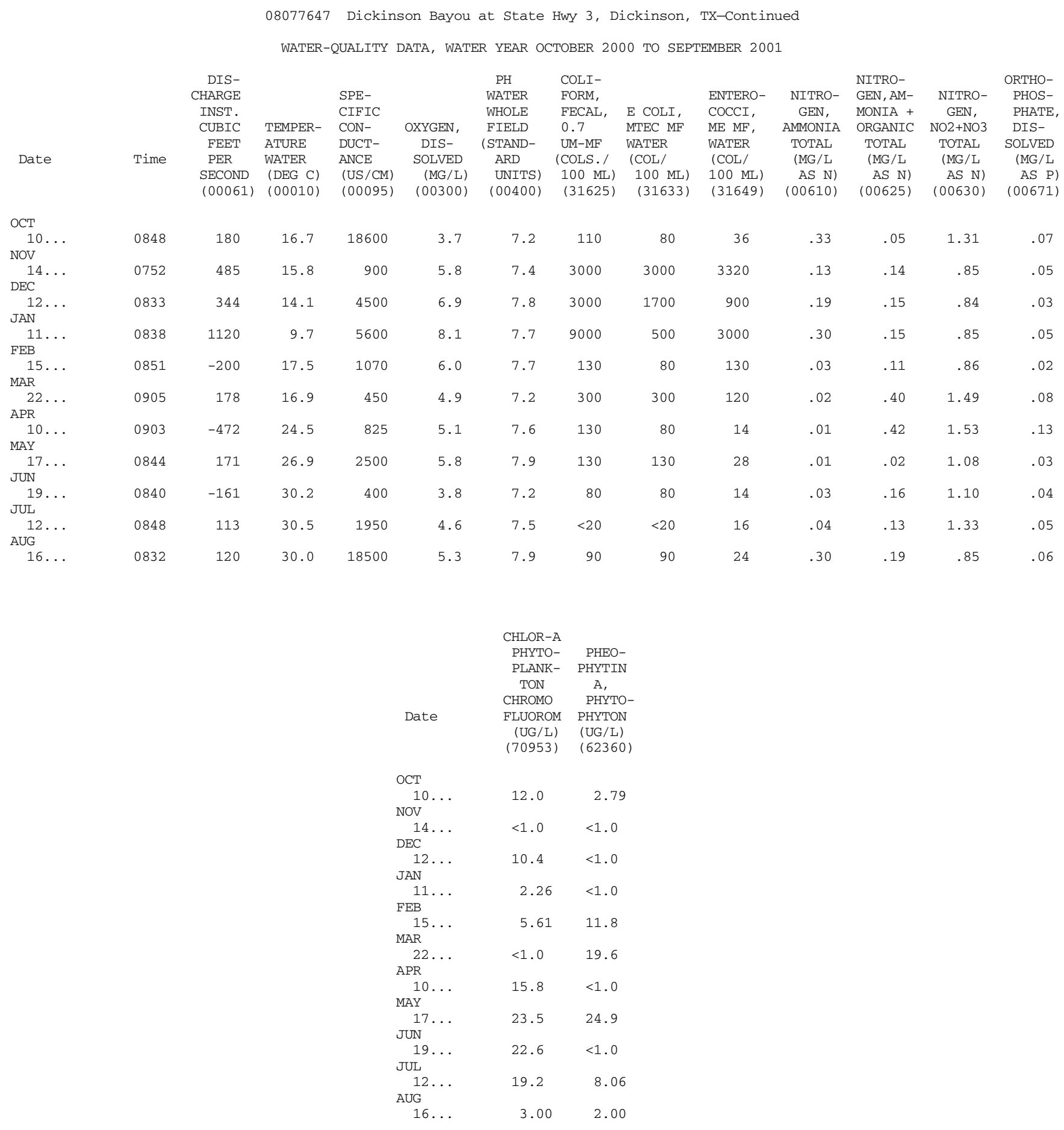

Remark codes used in this table:

$<--$ Less than

$>$-- Greater than 
Table 4. Periodically collected water-quality properties and constituents at six sites in Dickinson Bayou, July 2000August 2001-Continued

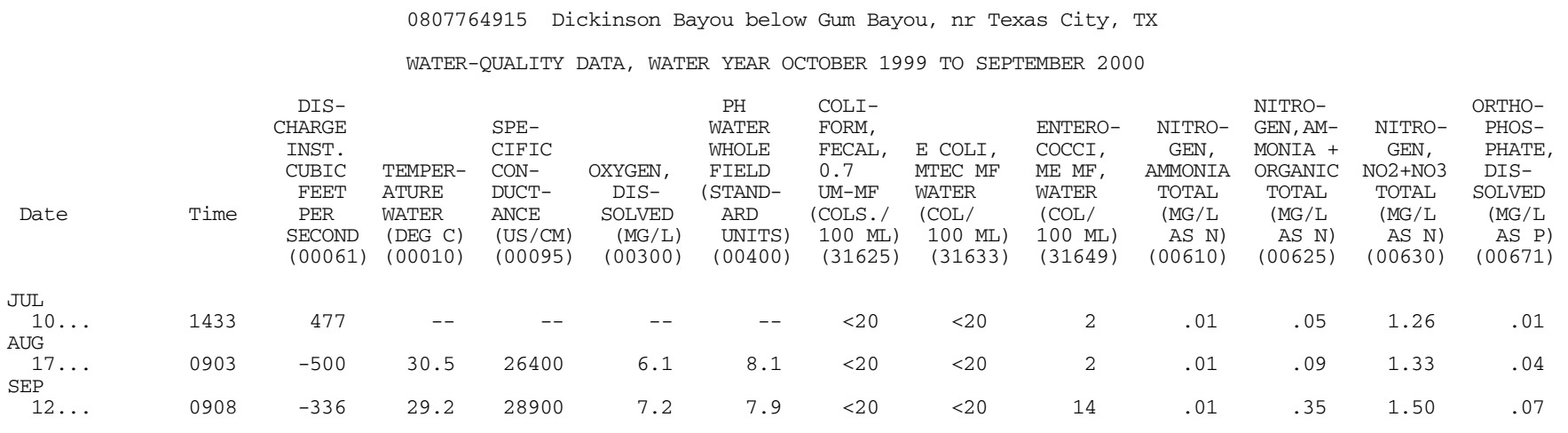

\begin{tabular}{|c|c|c|}
\hline Date & $\begin{array}{c}\text { CHLOR-A } \\
\text { PHYTO- } \\
\text { PLANK- } \\
\text { TON } \\
\text { CHROMO } \\
\text { FLUOROM } \\
\text { (UG/L) } \\
(70953)\end{array}$ & $\begin{array}{c}\text { PHEO- } \\
\text { PHYTIN } \\
\text { A, } \\
\text { PHYTO- } \\
\text { PHYTON } \\
\text { (UG/L) } \\
(62360)\end{array}$ \\
\hline $\begin{array}{l}\text { JUL } \\
10 \ldots\end{array}$ & 25.6 & 9.26 \\
\hline $\begin{array}{l}\text { AUG } \\
17 \ldots \\
\text { SEP }\end{array}$ & 15.6 & 9.98 \\
\hline $12 \ldots$ & 22.4 & 7.44 \\
\hline
\end{tabular}


Table 4. Periodically collected water-quality properties and constituents at six sites in Dickinson Bayou, July 2000August 2001-Continued

\begin{tabular}{|c|c|c|c|c|c|c|c|c|c|c|c|c|c|}
\hline \multirow[b]{2}{*}{ Date } & \multicolumn{6}{|c|}{ WATER-QUALITY DATA, WATER YEAR OCTOBER 2000 TO SEPTEMBER 2001} & \multicolumn{4}{|c|}{ Bayou, nr Texas City, TX-Continued } & & \multirow{2}{*}{\multicolumn{2}{|c|}{$\begin{array}{cc}\text { NITRO- } & \text { ORTHO- } \\
\text { GEN, } & \text { PHATE, } \\
\text { NO2+NO3 } & \text { DIS- } \\
\text { TOTAL } & \text { SOLVED } \\
\text { (MG/L } & \text { (MG/L } \\
\text { AS N) } & \text { AS P) } \\
(00630) & (00671)\end{array}$}} \\
\hline & Time & $\begin{array}{l}\text { DIS- } \\
\text { CHARGE } \\
\text { INST. } \\
\text { CUBIC } \\
\text { FEET } \\
\text { PER } \\
\text { SECOND } \\
(00061)\end{array}$ & $\begin{array}{l}\text { TEMPER- } \\
\text { ATURE } \\
\text { WATER } \\
(\text { DEG C) } \\
(00010)\end{array}$ & $\begin{array}{l}\text { SPE- } \\
\text { CIFIC } \\
\text { CON- } \\
\text { DUCT- } \\
\text { ANCE } \\
(\text { US/CM) } \\
(00095)\end{array}$ & $\begin{array}{l} \\
\text { OXYGEN, } \\
\text { DIS- } \\
\text { SOLVED } \\
\text { (MG/L) } \\
(00300)\end{array}$ & $\begin{array}{l}\text { PH } \\
\text { WATER } \\
\text { WHOLE } \\
\text { FIELD } \\
\text { (STAND- } \\
\text { ARD } \\
\text { UNITS) } \\
(00400)\end{array}$ & $\begin{array}{ll}\text { COLI- } & \\
\text { FORM, } & \\
\text { FECAL, } & \text { E } \\
0.7 & \text { M' } \\
\text { UM-MF } & \text { WI } \\
\text { (COLS./ } & ( \\
100 \mathrm{ML}) & \\
(31625) & \end{array}$ & $\begin{array}{l}\text { E COLI, } \\
\text { MTEC MF } \\
\text { WATER } \\
\text { (COL/ } \\
100 \mathrm{ML}) \\
(31633)\end{array}$ & $\begin{array}{l}\text { ENTERO- } \\
\text { COCCI, } \\
\text { ME MF, } \\
\text { WATER } \\
\text { (COL/ } \\
100 \mathrm{ML}) \\
(31649)\end{array}$ & $\begin{array}{l}\text { NITRO- } \\
\text { GEN, } \\
\text { AMMONIA } \\
\text { TOTAL } \\
\text { (MG/L } \\
\text { AS N) } \\
(00610)\end{array}$ & $\begin{array}{l}\text { NITRO- } \\
\text { GEN, AM- } \\
\text { MONIA + } \\
\text { ORGANIC } \\
\text { TOTAL } \\
\text { (MG/L } \\
\text { AS N) } \\
(00625)\end{array}$ & & \\
\hline \multicolumn{14}{|l|}{ OCT } \\
\hline $\begin{array}{l}10 \ldots \\
\text { NOV }\end{array}$ & 0911 & -467 & 14.3 & 26000 & 6.6 & 7.5 & $<20$ & $<20$ & 16 & .14 & .43 & 1.15 & .05 \\
\hline \multicolumn{14}{|l|}{$\mathrm{DEC}$} \\
\hline $\begin{array}{l}12 \ldots \\
\text { JAN }\end{array}$ & 0854 & 612 & 14.2 & 7500 & 7.4 & 7.9 & 800 & 800 & 96 & .44 & .33 & .92 & .05 \\
\hline $\begin{array}{l}11 \cdots \\
\mathrm{FEB}\end{array}$ & 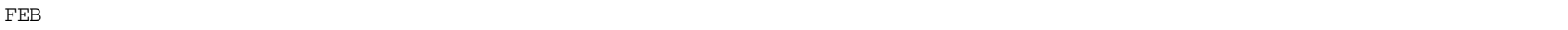 & 1600 & 10.0 & 10000 & 8.7 & $7.7>1$ & $>16000>$ & $>16000$ & 380 & .34 & .25 & .97 & .04 \\
\hline \multicolumn{14}{|l|}{ MAR } \\
\hline $\begin{array}{l}22 \ldots \\
\operatorname{APR}\end{array}$ & 0938 & 564 & 16.9 & 680 & 6.5 & 7.3 & 500 & 500 & 60 & .04 & .53 & 1.39 & .24 \\
\hline \multicolumn{12}{|l|}{ MAY } & 1.28 & .10 \\
\hline \multicolumn{12}{|l|}{ JUN } & 1.09 & .01 \\
\hline $\begin{array}{c}19 . . \\
\text { JUL }\end{array}$ & 0902 & -361 & \multicolumn{8}{|c|}{ JUL } & .24 & 1.25 & .06 \\
\hline $\begin{array}{c}12 \ldots \\
\text { AUG }\end{array}$ & 0912 & 381 & 31.0 & 3200 & 7.6 & 8.2 & $<20$ & $<20$ & 32 & .01 & .08 & 1.38 & .01 \\
\hline $16 \ldots$ & 0857 & 410 & 29.0 & 21000 & 4.9 & 7.9 & 20 & 20 & 4 & .01 & .16 & .95 & .04 \\
\hline & & & & & Date & $\begin{array}{c}\text { CHLOR-A } \\
\text { PHYTO- } \\
\text { PLANK- } \\
\text { TON } \\
\text { CHROMO } \\
\text { FLUOROM } \\
\text { (UG/L) } \\
(70953)\end{array}$ & $\begin{array}{cc}-\mathrm{A} & \\
- & \text { PHEO- } \\
\text { PHYTIN } \\
\text { A, } \\
\text { PHYTO- } \\
\text { PHYTON } \\
(\text { UG/L) } \\
(62360)\end{array}$ & & & & & & \\
\hline & & & & & $\begin{array}{c}\text { OCT } \\
10 \ldots \\
\text { NOV } \\
14 \ldots \\
\text { DEC } \\
12 \ldots \\
\text { JAN } \\
11 \ldots \\
\text { FEB } \\
15 \ldots \\
\text { MAR } \\
22 \ldots \\
\text { APR } \\
10 \ldots \\
\text { MAY } \\
17 \ldots \\
\text { JUN } \\
19 \ldots \\
\text { JUL } \\
12 \ldots \\
\text { AUG } \\
16 \ldots\end{array}$ & $\begin{array}{r}<1.0 \\
<1.0 \\
4.41 \\
2.40 \\
4.45 \\
<1.0 \\
2.24 \\
18.6 \\
19.2 \\
15.5 \\
4.00\end{array}$ & $\begin{array}{c}12.4 \\
1.25 \\
<1.0 \\
3.76 \\
11.1 \\
20.3 \\
3.51 \\
5.77 \\
6.13 \\
8.44 \\
3.00\end{array}$ & & & & & & \\
\hline $\begin{array}{l}\text { Remark } \\
<-- \text { Les } \\
>-- \text { Gre }\end{array}$ & $\begin{array}{l}\text { sed in } \\
\text { han }\end{array}$ & his table & & & & & & & & & & & \\
\hline
\end{tabular}


Table 5. Periodically collected water-quality properties and constituents at four sites in Armand Bayou, August 2000-July 2001

[Numbers in parentheses below property and constituent names are USGS National Water Quality Laboratory parameter codes]

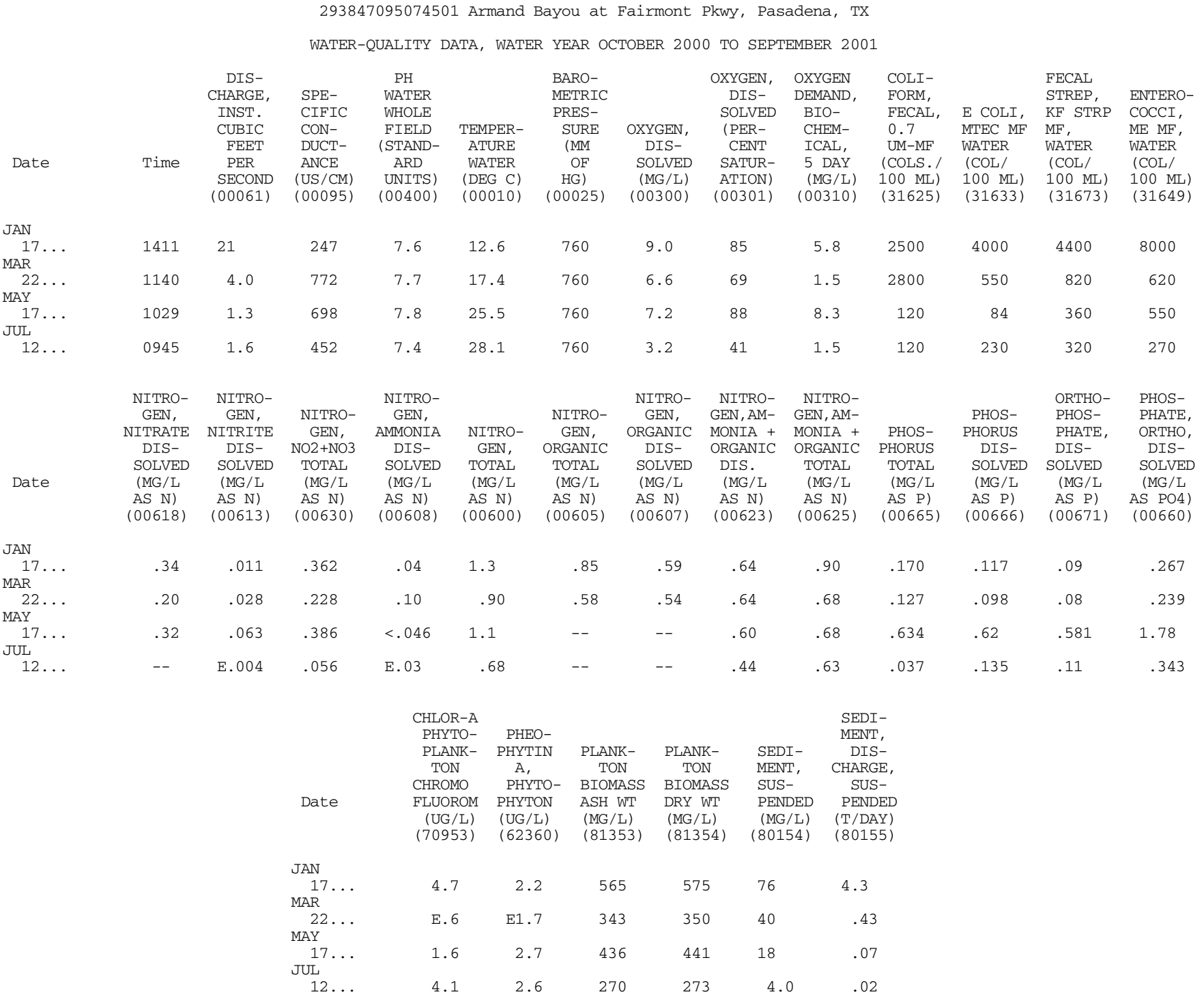

Remark codes used in this report:

$<--$ Less than

E -- Estimated value 
Table 5. Periodically collected water-quality properties and constituents at four sites in Armand Bayou, August 2000-July 2001-Continued

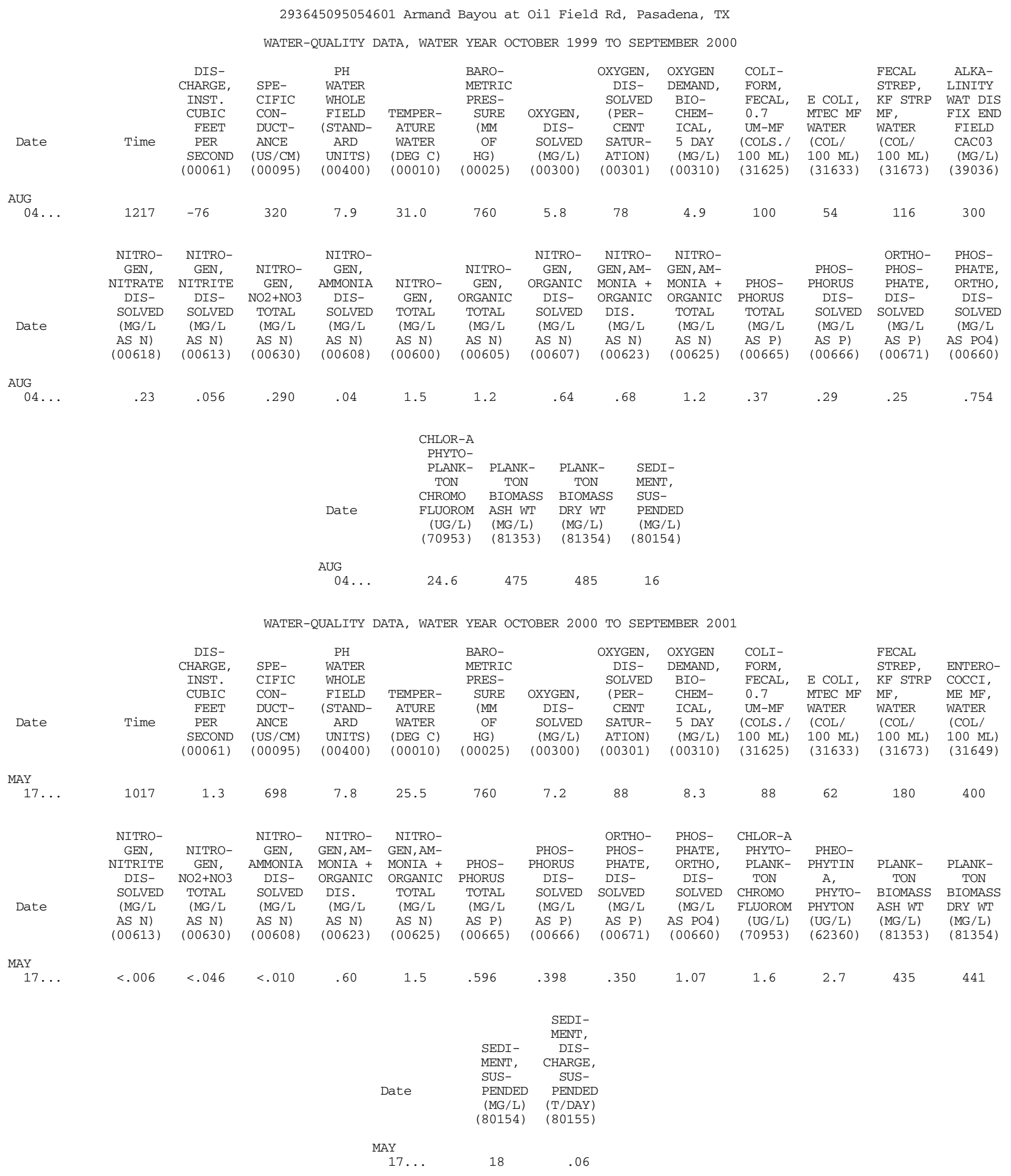


Table 5. Periodically collected water-quality properties and constituents at four sites in Armand Bayou, August 2000-July 2001-Continued

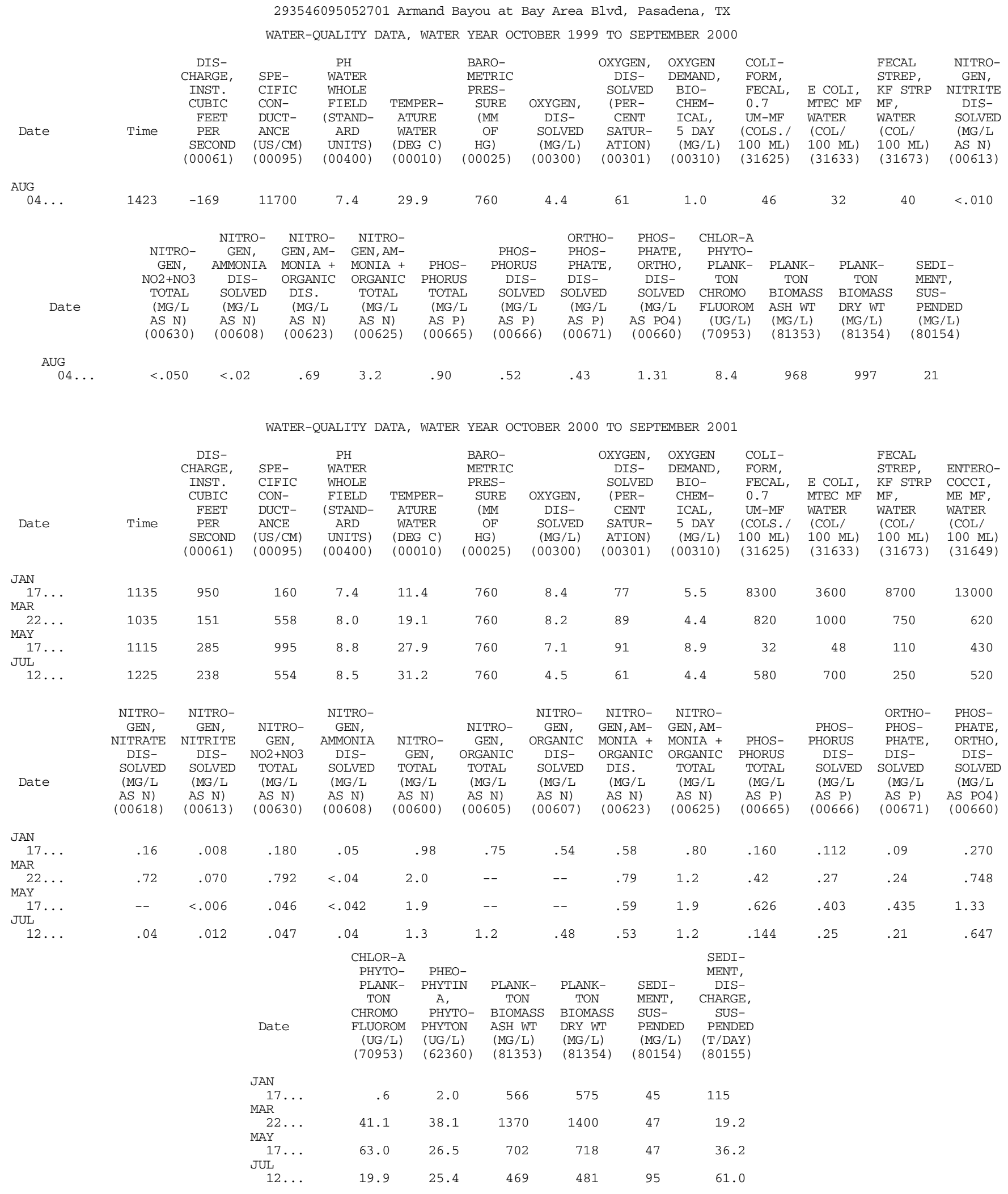

Remark codes used in this report:

$<--$ Less than 
Table 5. Periodically collected water-quality properties and constituents at four sites in Armand Bayou, August 2000-July 2001-Continued

08077630 Horsepen Bayou at Bay Area Blvd, Houston, TX

WATER-QUALITY DATA, WATER YEAR OCTOBER 1999 TO SEPTEMBER 2000

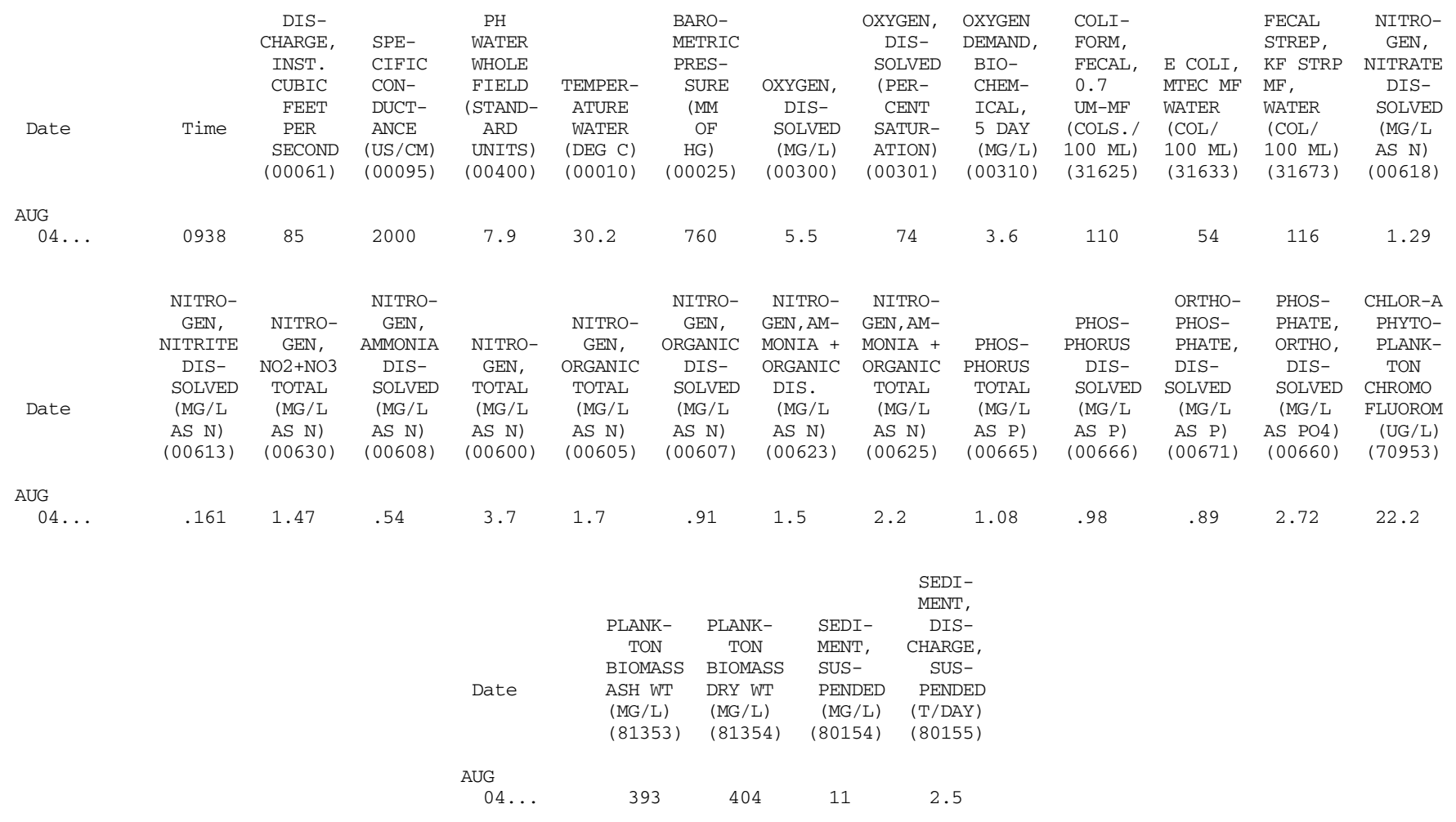

WATER-QUALITY DATA, WATER YEAR OCTOBER 2000 TO SEPTEMBER 2001

\begin{tabular}{|c|c|c|c|c|c|c|c|c|c|c|c|c|c|}
\hline Date & Time & $\begin{array}{c}\text { DIS- } \\
\text { CHARGE, } \\
\text { INST. } \\
\text { CUBIC } \\
\text { FEET } \\
\text { PER } \\
\text { SECOND } \\
(00061)\end{array}$ & $\begin{array}{l}\text { SPE- } \\
\text { CIFIC } \\
\text { CON- } \\
\text { DUCT- } \\
\text { ANCE } \\
\text { (US/CM) } \\
(00095)\end{array}$ & $\begin{array}{c}\text { PH } \\
\text { WATER } \\
\text { WHOLE } \\
\text { FIELD } \\
\text { (STAND- } \\
\text { ARD } \\
\text { UNITS) } \\
(00400)\end{array}$ & $\begin{array}{c}\text { TEMPER- } \\
\text { ATURE } \\
\text { WATER } \\
(\text { DEG C) } \\
(00010)\end{array}$ & $\begin{array}{c}\text { BARO- } \\
\text { METRIC } \\
\text { PRES- } \\
\text { SURE } \\
\text { (MM } \\
\text { OF } \\
\text { HG) } \\
(00025)\end{array}$ & $\begin{array}{c}\text { OXYGEN, } \\
\text { DIS- } \\
\text { SOLVED } \\
(\text { MG } / L) \\
(00300)\end{array}$ & $\begin{array}{c}\text { OXYGEN, } \\
\text { DIS- } \\
\text { SOLVED } \\
\text { (PER- } \\
\text { CENT } \\
\text { SATUR- } \\
\text { ATION) } \\
\text { (00301) }\end{array}$ & $\begin{array}{c}\text { OXYGEN } \\
\text { DEMAND, } \\
\text { BIO- } \\
\text { CHEM- } \\
\text { ICAL, } \\
5 \text { DAY } \\
(\text { MG } / L) \\
(00310)\end{array}$ & $\begin{array}{l}\text { COLI- } \\
\text { FORM, } \\
\text { FECAL, } \\
0.7 \\
\text { UM-MF } \\
\text { (COLS. / } \\
100 \mathrm{ML}) \\
(31625)\end{array}$ & $\begin{array}{l}\text { E COLI, } \\
\text { MTEC MF } \\
\text { WATER } \\
\text { (COL/ } \\
100 \mathrm{ML}) \\
(31633)\end{array}$ & $\begin{array}{l}\text { FECAL } \\
\text { STREP, } \\
\text { KF STRP } \\
\text { MF, } \\
\text { WATER } \\
\text { (COL/ } \\
100 \mathrm{ML}) \\
(31673)\end{array}$ & $\begin{array}{l}\text { ENTERO- } \\
\text { COCCI, } \\
\text { ME MF, } \\
\text { WATER } \\
\text { (COL/ } \\
100 \text { ML) } \\
\text { (31649) }\end{array}$ \\
\hline \multicolumn{14}{|l|}{ JAN } \\
\hline$\underset{\operatorname{MAR}}{17 \ldots}$ & 1308 & 312 & 260 & 7.6 & 12.2 & 760 & 8.9 & 83 & 6.2 & 2900 & 2900 & 2300 & 7300 \\
\hline$\underset{\text { MAY }}{22} \ldots$ & 0912 & .0 & 875 & 7.7 & 18.0 & 760 & 8.6 & 91 & 2.9 & 2300 & 24 & 1500 & 950 \\
\hline $\begin{array}{l}17 \\
\text { JUL }\end{array}$ & 0934 & 20 & 275 & 8.5 & 27.8 & 760 & 10.5 & 134 & 6.2 & 130 & 110 & 120 & 150 \\
\hline $12 \ldots$ & 1328 & 40 & 803 & 8.5 & 32.1 & 760 & 8.8 & 121 & 2.7 & E160 & 1300 & 190 & E310 \\
\hline Date & $\begin{array}{c}\text { NITRO- } \\
\text { GEN, } \\
\text { NITRATE } \\
\text { DIS- } \\
\text { SOLVED } \\
\text { (MG/L } \\
\text { AS N) } \\
(00618)\end{array}$ & $\begin{array}{c}\text { NITRO- } \\
\text { GEN, } \\
\text { NITRITE } \\
\text { DIS- } \\
\text { SOLVED } \\
\text { (MG/L } \\
\text { AS N) } \\
(00613)\end{array}$ & $\begin{array}{c}\text { NITRO- } \\
\text { GEN, } \\
\text { NO2+NO3 } \\
\text { TOTAL } \\
(\text { MG / L } \\
\text { AS N) } \\
(00630)\end{array}$ & $\begin{array}{c}\text { NITRO- } \\
\text { GEN, } \\
\text { AMMONIA } \\
\text { DIS- } \\
\text { SOLVED } \\
\text { (MG/L } \\
\text { AS N) } \\
(00608)\end{array}$ & $\begin{array}{c}\text { NITRO- } \\
\text { GEN, } \\
\text { TOTAL } \\
\text { (MG/L } \\
\text { AS N) } \\
(00600)\end{array}$ & $\begin{array}{c}\text { NITRO- } \\
\text { GEN, } \\
\text { ORGANIC } \\
\text { TOTAL } \\
\text { (MG/L } \\
\text { AS N) } \\
(00605)\end{array}$ & $\begin{array}{c}\text { NITRO- } \\
\text { GEN, } \\
\text { ORGANIC } \\
\text { DIS- } \\
\text { SOLVED } \\
\text { (MG/L } \\
\text { AS N) } \\
(00607)\end{array}$ & $\begin{array}{c}\text { NITRO- } \\
\text { GEN, AM- } \\
\text { MONIA + } \\
\text { ORGANIC } \\
\text { DIS. } \\
(\text { MG/L } \\
\text { AS N) } \\
(00623)\end{array}$ & $\begin{array}{c}\text { NITRO- } \\
\text { GEN, AM- } \\
\text { MONIA + } \\
\text { ORGANIC } \\
\text { TOTAL } \\
\text { (MG/L } \\
\text { AS N) } \\
(00625)\end{array}$ & $\begin{array}{c}\text { PHOS- } \\
\text { PHORUS } \\
\text { TOTAL } \\
\text { (MG/L } \\
\text { AS P) } \\
(00665)\end{array}$ & $\begin{array}{c}\text { PHOS- } \\
\text { PHORUS } \\
\text { DIS- } \\
\text { SOLVED } \\
\text { (MG/L } \\
\text { AS P) } \\
(00666)\end{array}$ & $\begin{array}{c}\text { ORTHO- } \\
\text { PHOS- } \\
\text { PHATE, } \\
\text { DIS- } \\
\text { SOLVED } \\
\text { (MG/L } \\
\text { AS P) } \\
(00671)\end{array}$ & $\begin{array}{c}\text { PHOS- } \\
\text { PHATE, } \\
\text { ORTHO, } \\
\text { DIS- } \\
\text { SOLVED } \\
\text { (MG/L } \\
\text { AS PO4) } \\
(00660)\end{array}$ \\
\hline
\end{tabular}

\begin{tabular}{|c|c|c|c|c|c|c|c|c|c|c|c|c|c|}
\hline \multicolumn{14}{|l|}{ JAN } \\
\hline $17 \ldots$ & .33 & .010 & .360 & .04 & 1.2 & .76 & .60 & .65 & .80 & .140 & .111 & .08 & .258 \\
\hline \multicolumn{14}{|l|}{ MAR } \\
\hline $22 \ldots$ & 3.42 & .093 & 3.51 & .09 & 4.6 & .97 & .70 & .79 & 1.1 & .66 & .60 & .57 & 1.75 \\
\hline \multicolumn{14}{|l|}{ MAY } \\
\hline $17 \ldots$ & -- & $<.006$ & 1.10 & .131 & 2.5 & 1.3 & .66 & .79 & 1.4 & .71 & .61 & .57 & 1.76 \\
\hline \multicolumn{14}{|l|}{ JUL } \\
\hline $12 \ldots$ & 1.72 & .073 & 1.80 & .18 & 2.4 & .46 & .83 & 1.0 & .65 & .138 & .60 & .47 & 1.45 \\
\hline
\end{tabular}


Table 5. Periodically collected water-quality properties and constituents at four sites in Armand Bayou, August 2000-July 2001-Continued

08077630 Horsepen Bayou at Bay Area Blvd, Houston, TX-Continued WATER-QUALITY DATA, WATER YEAR OCTOBER 2000 TO SEPTEMBER 2001

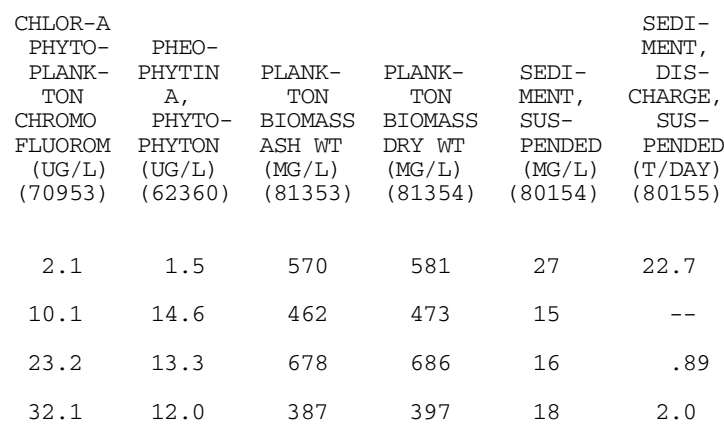

Remark codes used in this report: 
Table 6. Periodically collected water-quality properties and constituents at six sites in the San Bernard River, January 2001-August 2002

[Numbers in parentheses below property and constituent names are USGS National Water Quality Laboratory parameter codes]

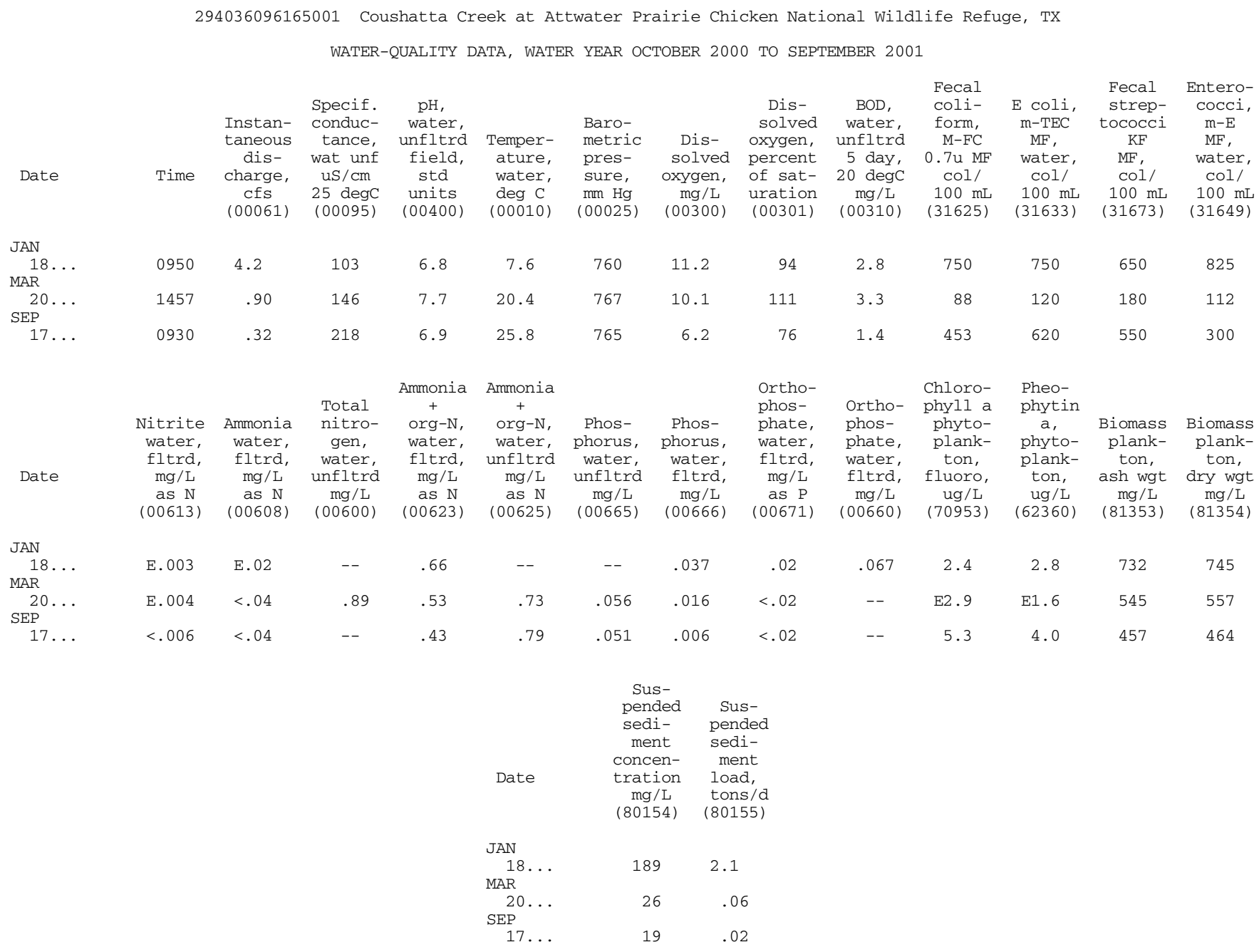


Table 6. Periodically collected water-quality properties and constituents at six sites in the San Bernard River, January 2001-August 2002-Continued

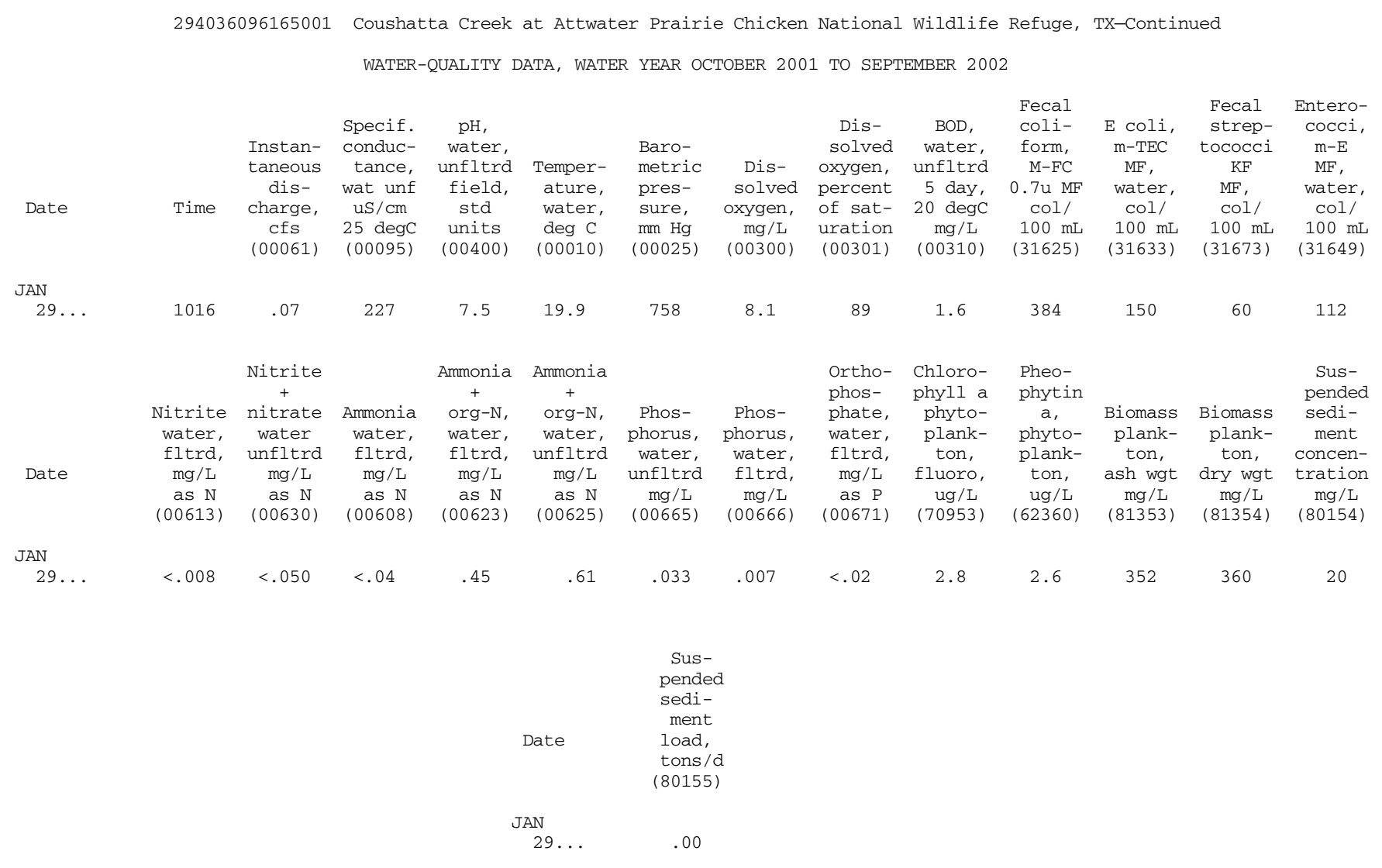

Remark codes used in this report:

$<--$ Less than

E -- Estimated value 
Table 6. Periodically collected water-quality properties and constituents at six sites in the San Bernard River, January 2001-August 2002-Continued

293211096110301 West Bernard Creek at CR 252, nr East Bernard, TX

WATER-QUALITY DATA，WATER YEAR OCTOBER 2000 TO SEPTEMBER 2001

\begin{tabular}{|c|c|c|c|c|c|c|c|c|c|c|c|c|c|}
\hline Date & Time & $\begin{array}{c}\text { Instan- } \\
\text { taneous } \\
\text { dis- } \\
\text { charge, } \\
\text { cfs } \\
(00061)\end{array}$ & $\begin{array}{c}\text { Specif. } \\
\text { conduc- } \\
\text { tance, } \\
\text { wat unf } \\
\text { uS/cm } \\
25 \text { degc } \\
(00095)\end{array}$ & $\begin{array}{c}\text { pH, } \\
\text { water, } \\
\text { unfltrd } \\
\text { field, } \\
\text { std } \\
\text { units } \\
(00400)\end{array}$ & $\begin{array}{c}\text { Temper- } \\
\text { ature, } \\
\text { water, } \\
\text { deg C } \\
(00010)\end{array}$ & $\begin{array}{l}\text { Baro- } \\
\text { metric } \\
\text { pres- } \\
\text { sure, } \\
\text { mm Hg } \\
(00025)\end{array}$ & $\begin{array}{c}\text { Dis- } \\
\text { solved } \\
\text { oxygen, } \\
\text { mg/L } \\
(00300)\end{array}$ & $\begin{array}{l}\text { Dis- } \\
\text { solved } \\
\text { oxygen, } \\
\text { percent } \\
\text { of sat- } \\
\text { uration } \\
\text { (00301) }\end{array}$ & $\begin{array}{c}\text { BOD, } \\
\text { water, } \\
\text { unfltrd } \\
5 \text { day, } \\
20 \text { degC } \\
\mathrm{mg} / \mathrm{L} \\
(00310)\end{array}$ & $\begin{array}{c}\text { Fecal } \\
\text { coli- } \\
\text { form, } \\
\text { M-FC } \\
0.7 \mathrm{u} \mathrm{MF} \\
\mathrm{Col} / \\
100 \mathrm{~mL} \\
(31625)\end{array}$ & $\begin{array}{c}\text { E coli, } \\
\text { m-TEC } \\
\text { MF, } \\
\text { water, } \\
\text { col/ } \\
100 \mathrm{~mL} \\
(31633)\end{array}$ & $\begin{array}{c}\text { Fecal } \\
\text { strep- } \\
\text { tococci } \\
\text { KF } \\
\text { MF' } \\
\text { Col/ } \\
100 \mathrm{~mL} \\
(31673)\end{array}$ & $\begin{array}{c}\text { Entero- } \\
\text { cocci, } \\
\text { m-E } \\
\text { MF, } \\
\text { water, } \\
\text { col/ } \\
100 \mathrm{~mL} \\
\text { (31649) }\end{array}$ \\
\hline AN & & & & & & & & & & & & & \\
\hline $\begin{array}{c}18 \ldots \\
\text { MAR }\end{array}$ & 1045 & 237 & 133 & 6.8 & 8.1 & 760 & 9.9 & 84 & 4.0 & 2300 & 2100 & 1860 & 2300 \\
\hline$\underset{M A Y}{20 \ldots}$ & 1350 & 9.2 & 294 & 7.2 & 14.3 & 767 & 9.2 & 89 & 2.6 & 600 & 750 & 975 & 675 \\
\hline $15 \ldots$ & 0944 & 8.3 & 519 & 7.6 & 23.7 & 763 & 6.3 & 75 & 3.8 & 1480 & 1000 & 775 & 750 \\
\hline $\begin{array}{l}10 \ldots \\
\operatorname{SEP}\end{array}$ & 1017 & 16 & 514 & 7.9 & 27.5 & 760 & 5.9 & 75 & 1.0 & 442 & 1600 & 875 & 147 \\
\hline $17 \ldots$ & 1055 & 4.3 & 148 & 7.4 & 25.7 & 765 & 5.8 & 71 & 1.5 & 525 & 700 & 1000 & 775 \\
\hline Date & $\begin{array}{c}\text { Nitrate } \\
\text { water, } \\
\text { fltrd, } \\
\mathrm{mg} / \mathrm{L} \\
\text { as N } \\
(00618)\end{array}$ & $\begin{array}{c}\text { Nitrite } \\
\text { water, } \\
\text { fltrd, } \\
\mathrm{mg} / \mathrm{L} \\
\text { as N } \\
(00613)\end{array}$ & $\begin{array}{c}\text { Nitrite } \\
+ \\
\text { nitrate } \\
\text { water } \\
\text { unfltrd } \\
\mathrm{mg} / \mathrm{L} \\
\text { as } \mathrm{N} \\
(00630)\end{array}$ & $\begin{array}{c}\text { Ammonia } \\
\text { water, } \\
\text { fltrd, } \\
\mathrm{mg} / \mathrm{L} \\
\text { as N } \\
(00608)\end{array}$ & $\begin{array}{c}\text { Total } \\
\text { nitro- } \\
\text { gen, } \\
\text { water, } \\
\text { unfltrd } \\
\text { mg/L } \\
(00600)\end{array}$ & $\begin{array}{c}\text { Organic } \\
\text { nitro- } \\
\text { gen, } \\
\text { water, } \\
\text { unfltrd } \\
\text { mg/L } \\
(00605)\end{array}$ & $\begin{array}{c}\text { Organic } \\
\text { nitro- } \\
\text { gen, } \\
\text { water, } \\
\text { fltrd, } \\
\text { mg/L } \\
(00607)\end{array}$ & $\begin{array}{c}\text { Ammonia } \\
+ \\
\text { org-N, } \\
\text { water, } \\
\text { fltrd, } \\
\text { mg/L } \\
\text { as N } \\
(00623)\end{array}$ & $\begin{array}{c}\text { Ammonia } \\
+ \\
\text { org-N, } \\
\text { water, } \\
\text { unfltrd } \\
\text { mg/L } \\
\text { as N } \\
(00625)\end{array}$ & $\begin{array}{c}\text { Phos- } \\
\text { phorus, } \\
\text { water, } \\
\text { unfltrd } \\
\text { mg/L } \\
(00665)\end{array}$ & $\begin{array}{c}\text { Phos- } \\
\text { phorus, } \\
\text { water, } \\
\text { fltrd, } \\
\text { mg/L } \\
(00666)\end{array}$ & $\begin{array}{l}\text { Ortho- } \\
\text { phos- } \\
\text { phate, } \\
\text { water, } \\
\text { fltrd, } \\
\text { mg/L } \\
\text { as P } \\
(00671)\end{array}$ & $\begin{array}{l}\text { Ortho- } \\
\text { phos- } \\
\text { phate, } \\
\text { water, } \\
\text { fltrd, } \\
\mathrm{mg} / \mathrm{L} \\
(00660)\end{array}$ \\
\hline
\end{tabular}

\begin{tabular}{|c|c|c|c|c|c|c|c|c|c|c|c|c|c|}
\hline \multicolumn{14}{|l|}{ JAN } \\
\hline $18 \ldots$ & .11 & .006 & -- & .04 & -- & -- & .66 & .70 & -- & -- & .103 & .08 & .239 \\
\hline \multicolumn{14}{|l|}{ MAR } \\
\hline $20 \ldots$ & .21 & .018 & -- & .09 & 1.5 & 1.2 & .79 & .89 & 1.3 & .26 & .058 & .04 & .113 \\
\hline \multicolumn{14}{|l|}{ MAY } \\
\hline $15 \ldots$ & .36 & .070 & -- & .05 & 2.0 & 1.5 & .90 & .95 & 1.6 & .30 & .126 & .09 & .288 \\
\hline \multicolumn{14}{|l|}{ JUL } \\
\hline $10 \ldots$ & .18 & .008 & .191 & E.03 & 1.1 & -- & -- & .49 & .86 & .050 & .092 & .08 & .245 \\
\hline \multicolumn{14}{|l|}{ SEP } \\
\hline $17 \ldots$ & .37 & .035 & .413 & .04 & 1.7 & 1.3 & .84 & .89 & 1.3 & .29 & .174 & .14 & .417 \\
\hline
\end{tabular}

\begin{tabular}{|c|c|c|c|c|c|c|}
\hline Date & $\begin{array}{c}\text { Chloro- } \\
\text { phyll a } \\
\text { phyto- } \\
\text { plank- } \\
\text { ton, } \\
\text { fluoro, } \\
\text { ug/L } \\
\text { (70953) }\end{array}$ & $\begin{array}{c}\text { Pheo- } \\
\text { phytin } \\
\text { a, } \\
\text { phyto- } \\
\text { plank- } \\
\text { ton, } \\
\text { ug/L } \\
\text { (62360) }\end{array}$ & $\begin{array}{c}\text { Biomass } \\
\text { plank- } \\
\text { ton, } \\
\text { ash wgt } \\
\mathrm{mg} / \mathrm{L} \\
(81353)\end{array}$ & $\begin{array}{c}\text { Biomass } \\
\text { plank- } \\
\text { ton, } \\
\text { dry wgt } \\
\text { mg/L } \\
(81354)\end{array}$ & $\begin{array}{c}\text { Sus- } \\
\text { pended } \\
\text { sedi- } \\
\text { ment } \\
\text { concen- } \\
\text { tration } \\
\text { mg/L } \\
\text { (80154) }\end{array}$ & $\begin{array}{c}\text { Sus- } \\
\text { pended } \\
\text { sedi- } \\
\text { ment } \\
\text { load, } \\
\text { tons /d } \\
\text { (80155) }\end{array}$ \\
\hline JAN & & & & & & \\
\hline$\underset{\operatorname{MAR}}{18 \ldots}$ & 3.1 & 5.4 & 951 & 967 & 82 & 52 \\
\hline $20 \ldots$ & 4.8 & 11.1 & 1420 & 1450 & 65 & 1.6 \\
\hline $\begin{array}{l}15 \ldots \\
\text { JUL }\end{array}$ & 13.4 & 17.5 & 727 & 740 & 86 & 1.9 \\
\hline $\begin{array}{l}10 \ldots \\
\mathrm{EP}\end{array}$ & 3.0 & 5.6 & 320 & 326 & 76 & 3.3 \\
\hline $17 \ldots$ & 3.5 & 3.6 & 2840 & 2840 & 67 & .79 \\
\hline
\end{tabular}


Table 6. Periodically collected water-quality properties and constituents at six sites in the San Bernard River, January 2001-August 2002-Continued

293211096110301 West Bernard Creek at CR 252, nr East Bernard, TX-Continued WATER-QUALITY DATA, WATER YEAR OCTOBER 2001 TO SEPTEMBER 2002

\begin{tabular}{|c|c|c|c|c|c|c|c|c|c|c|c|c|c|}
\hline ate & Time & $\begin{array}{c}\text { Instan- } \\
\text { taneous } \\
\text { dis- } \\
\text { charge, } \\
\text { cfs } \\
(00061)\end{array}$ & $\begin{array}{c}\text { Specif. } \\
\text { conduc- } \\
\text { tance, } \\
\text { wat unf } \\
\text { uS/cm } \\
25 \text { degc } \\
(00095)\end{array}$ & $\begin{array}{c}\text { pH, } \\
\text { water, } \\
\text { unfltrd } \\
\text { field, } \\
\text { std } \\
\text { units } \\
(00400)\end{array}$ & $\begin{array}{c}\text { Temper- } \\
\text { ature, } \\
\text { water, } \\
\text { deg C } \\
(00010)\end{array}$ & $\begin{array}{l}\text { Baro- } \\
\text { metric } \\
\text { pres- } \\
\text { sure, } \\
\text { mm Hg } \\
(00025)\end{array}$ & $\begin{array}{c}\text { Dis- } \\
\text { solved } \\
\text { oxygen, } \\
\text { mg/L } \\
(00300)\end{array}$ & $\begin{array}{c}\text { Dis- } \\
\text { solved } \\
\text { oxygen, } \\
\text { percent } \\
\text { of sat- } \\
\text { uration } \\
\text { (00301) }\end{array}$ & $\begin{array}{c}\text { BOD, } \\
\text { water, } \\
\text { unfltrd } \\
5 \text { day, } \\
20 \text { degC } \\
\mathrm{mg} / \mathrm{L} \\
(00310)\end{array}$ & $\begin{array}{c}\text { Fecal } \\
\text { coli- } \\
\text { form, } \\
\text { M-FC } \\
0.7 \mathrm{u} \mathrm{MF} \\
\text { col/ } \\
100 \mathrm{~mL} \\
(31625)\end{array}$ & $\begin{array}{c}\text { E coli, } \\
\text { m-TEC } \\
\text { MF, } \\
\text { water, } \\
\text { col/ } \\
100 \mathrm{~mL} \\
(31633)\end{array}$ & $\begin{array}{c}\text { Fecal } \\
\text { strep- } \\
\text { tococci } \\
\mathrm{KF} \\
\mathrm{MF}, \\
\mathrm{COl} / \\
100 \mathrm{~mL} \\
(31673)\end{array}$ & $\begin{array}{c}\text { Entero- } \\
\text { cocci, } \\
\mathrm{m}-\mathrm{E} \\
\mathrm{MF}, \\
\text { water, } \\
\mathrm{Col} / \\
100 \mathrm{~mL} \\
(31649)\end{array}$ \\
\hline
\end{tabular}

\begin{tabular}{|c|c|c|c|c|c|c|c|c|c|c|c|c|c|}
\hline NOV & & & & & & & & & & & & & \\
\hline $13 \ldots$ & 1325 & .07 & 1030 & 7.5 & 19.2 & 760 & 4.1 & 44 & 2.2 & 112 & 140 & 379 & 293 \\
\hline JAN & & & & & & & & & & & & & \\
\hline $29 \ldots$ & 1203 & .29 & 2070 & 7.7 & 18.5 & 758 & 7.6 & 82 & 1.2 & 153 & 120 & 273 & 310 \\
\hline MAR & & & & & & & & & & & & & \\
\hline $12 \ldots$ & 1300 & .21 & 2360 & 8.2 & 16.9 & 760 & 10.0 & 105 & 2.0 & 153 & 28 & 360 & -- \\
\hline MAY & & & & & & & & & & & & & \\
\hline $29 \ldots$ & 1311 & 49 & 561 & 7.5 & 25.0 & 759 & 4.7 & 57 & 7.1 & 173 & 96 & 575 & -- \\
\hline AUG & & & & & & & & & & & & & \\
\hline $28 \ldots$ & 1052 & 40 & 450 & 7.2 & 27.8 & 765 & 2.6 & 34 & 9.0 & 750 & 260 & -- & 2300 \\
\hline Date & $\begin{array}{c}\text { Nitrate } \\
\text { water, } \\
\text { fltrd, } \\
\text { mg/L } \\
\text { as N } \\
(00618)\end{array}$ & $\begin{array}{c}\text { Nitrite } \\
\text { water, } \\
\text { fltrd, } \\
\text { mg/L } \\
\text { as N } \\
\text { (00613) }\end{array}$ & $\begin{array}{c}\text { Nitrite } \\
+ \\
\text { nitrate } \\
\text { water } \\
\text { unfltrd } \\
\text { mg/L } \\
\text { as N } \\
(00630)\end{array}$ & $\begin{array}{c}\text { Ammonia } \\
\text { water, } \\
\text { fltrd, } \\
\text { mg/L } \\
\text { as N } \\
(00608)\end{array}$ & $\begin{array}{c}\text { Total } \\
\text { nitro- } \\
\text { gen, } \\
\text { water, } \\
\text { unfltrd } \\
\text { mg/L } \\
(00600)\end{array}$ & $\begin{array}{c}\text { Organic } \\
\text { nitro- } \\
\text { gen, } \\
\text { water, } \\
\text { unfltrd } \\
\text { mg/L } \\
(00605)\end{array}$ & $\begin{array}{c}\text { Organic } \\
\text { nitro- } \\
\text { gen, } \\
\text { water, } \\
\text { fltrd, } \\
\text { mg/L } \\
(00607)\end{array}$ & $\begin{array}{c}\text { Ammonia } \\
+ \\
\text { org-N, } \\
\text { water, } \\
\text { fltrd, } \\
\text { mg/L } \\
\text { as N } \\
(00623)\end{array}$ & $\begin{array}{c}\text { Ammonia } \\
+ \\
\text { org-N, } \\
\text { water, } \\
\text { unfltrd } \\
\text { mg/L } \\
\text { as N } \\
(00625)\end{array}$ & $\begin{array}{c}\text { Phos- } \\
\text { phorus, } \\
\text { water, } \\
\text { unfltrd } \\
\text { mg/L } \\
(00665)\end{array}$ & $\begin{array}{c}\text { Phos- } \\
\text { phorus, } \\
\text { water, } \\
\text { fltrd, } \\
\text { mg/L } \\
(00666)\end{array}$ & $\begin{array}{c}\text { Ortho- } \\
\text { phos- } \\
\text { phate, } \\
\text { water, } \\
\text { fltrd, } \\
\text { mg/L } \\
\text { as P } \\
(00671)\end{array}$ & $\begin{array}{c}\text { Ortho- } \\
\text { phos- } \\
\text { phate, } \\
\text { water, } \\
\text { fltrd, } \\
\mathrm{mg} / \mathrm{L} \\
(00660)\end{array}$ \\
\hline
\end{tabular}

\begin{tabular}{|c|c|c|c|c|c|c|c|c|c|c|c|c|c|}
\hline \multicolumn{14}{|l|}{ NOV } \\
\hline $13 \ldots$ & -- & E.007 & $<.10$ & .05 & .95 & .83 & .75 & .81 & .88 & .199 & .139 & $<.02$ & -- \\
\hline \multicolumn{14}{|l|}{ JAN } \\
\hline $29 \ldots$ & -- & E.006 & .095 & .05 & .64 & .50 & .43 & .48 & .55 & .062 & .036 & .02 & .058 \\
\hline \multicolumn{14}{|l|}{ MAR } \\
\hline $12 \ldots$ & -- & $<.008$ & $<.050$ & $<.04$ & -- & -- & -- & .41 & .85 & .19 & .021 & $<.02$ & -- \\
\hline \multicolumn{14}{|l|}{ MAY } \\
\hline $29 \ldots$ & .97 & .259 & 1.25 & .38 & 3.8 & 2.1 & 1.7 & 2.1 & 2.5 & .188 & .088 & .06 & .193 \\
\hline \multicolumn{14}{|l|}{ AUG } \\
\hline $28 \ldots$ & .21 & .130 & .380 & 2.15 & 4.0 & 1.5 & 1.4 & 3.6 & 3.7 & 34 & 193 & 14 & .420 \\
\hline
\end{tabular}

\begin{tabular}{|c|c|c|c|c|c|c|}
\hline Date & $\begin{array}{c}\text { Chloro- } \\
\text { phyll a } \\
\text { phyto- } \\
\text { plank- } \\
\text { ton, } \\
\text { fluoro, } \\
\text { ug/L } \\
(70953)\end{array}$ & $\begin{array}{c}\text { Pheo- } \\
\text { phytin } \\
\text { a, } \\
\text { phyto- } \\
\text { plank- } \\
\text { ton, } \\
\text { ug/L } \\
(62360)\end{array}$ & $\begin{array}{c}\text { Biomass } \\
\text { plank- } \\
\text { ton, } \\
\text { ash wgt } \\
\mathrm{mg} / \mathrm{L} \\
(81353)\end{array}$ & $\begin{array}{c}\text { Biomass } \\
\text { plank- } \\
\text { ton, } \\
\text { dry wgt } \\
\text { mg/L } \\
(81354)\end{array}$ & $\begin{array}{c}\text { Sus- } \\
\text { pended } \\
\text { sedi- } \\
\text { ment } \\
\text { concen- } \\
\text { tration } \\
\text { mg/L } \\
(80154)\end{array}$ & $\begin{array}{c}\text { Sus- } \\
\text { pended } \\
\text { sedi- } \\
\text { ment } \\
\text { load, } \\
\text { tons / d } \\
(80155)\end{array}$ \\
\hline
\end{tabular}

\begin{tabular}{|c|c|c|c|c|c|c|}
\hline \multicolumn{7}{|l|}{ NOV } \\
\hline $13 \ldots$ & 1.5 & .8 & 282 & 287 & 5 & .01 \\
\hline \multicolumn{7}{|l|}{ JAN } \\
\hline $29 \ldots$ & 1.8 & 1.7 & 330 & 335 & 12 & .01 \\
\hline \multicolumn{7}{|l|}{ MAR } \\
\hline $12 \ldots$ & 2.2 & 1.8 & -- & -- & 20 & .01 \\
\hline \multicolumn{7}{|l|}{ MAY } \\
\hline $29 \ldots$ & 8.9 & 10.8 & 356 & 364 & 84 & 11 \\
\hline \multicolumn{7}{|l|}{ AUG } \\
\hline $28 \ldots$ & E5. 5 & $\mathrm{E} 6.3$ & E432 & E446 & 37 & 4.0 \\
\hline
\end{tabular}

Remark codes used in this report:

$<--$ Less than

E -- Estimated value 
Table 6. Periodically collected water-quality properties and constituents at six sites in the San Bernard River, January 2001-August 2002-Continued

293123096073001 Gum Tree Branch at CR 252, nr East Bernard, TX

WATER-QUALITY DATA，WATER YEAR OCTOBER 2000 TO SEPTEMBER 2001

\begin{tabular}{|c|c|c|c|c|c|c|c|c|c|c|c|c|c|}
\hline Date & Time & $\begin{array}{c}\text { Instan- } \\
\text { taneous } \\
\text { dis- } \\
\text { charge, } \\
\text { cfs } \\
(00061)\end{array}$ & $\begin{array}{c}\text { Specif. } \\
\text { conduc- } \\
\text { tance, } \\
\text { wat unf } \\
\text { uS/cm } \\
25 \text { degc } \\
(00095)\end{array}$ & $\begin{array}{c}\text { pH, } \\
\text { water, } \\
\text { unfltrd } \\
\text { field, } \\
\text { std } \\
\text { units } \\
(00400)\end{array}$ & $\begin{array}{c}\text { Temper- } \\
\text { ature, } \\
\text { water, } \\
\text { deg C } \\
(00010)\end{array}$ & $\begin{array}{l}\text { Baro- } \\
\text { metric } \\
\text { pres- } \\
\text { sure, } \\
\text { mm Hg } \\
(00025)\end{array}$ & $\begin{array}{c}\text { Dis- } \\
\text { solved } \\
\text { oxygen, } \\
\text { mg/L } \\
(00300)\end{array}$ & $\begin{array}{l}\text { Dis- } \\
\text { solved } \\
\text { oxygen, } \\
\text { percent } \\
\text { of sat- } \\
\text { uration } \\
\text { (00301) }\end{array}$ & $\begin{array}{c}\text { BOD, } \\
\text { water, } \\
\text { unfltrd } \\
5 \text { day, } \\
20 \text { degC } \\
\mathrm{mg} / \mathrm{L} \\
(00310)\end{array}$ & $\begin{array}{c}\text { Fecal } \\
\text { coli- } \\
\text { form, } \\
\text { M-FC } \\
0.7 \mathrm{u} \mathrm{MF} \\
\mathrm{Col} / \\
100 \mathrm{~mL} \\
(31625)\end{array}$ & $\begin{array}{c}\text { E coli, } \\
\text { m-TEC } \\
\text { MF, } \\
\text { water, } \\
\text { col/ } \\
100 \mathrm{~mL} \\
(31633)\end{array}$ & $\begin{array}{c}\text { Fecal } \\
\text { strep- } \\
\text { tococci } \\
\text { KF } \\
\text { MF, } \\
\text { col/ } \\
100 \mathrm{~mL} \\
(31673)\end{array}$ & $\begin{array}{c}\text { Entero- } \\
\text { cocci, } \\
\text { m-E } \\
\text { MF, } \\
\text { water, } \\
\text { col/ } \\
100 \mathrm{~mL} \\
\text { (31649) }\end{array}$ \\
\hline \multicolumn{14}{|l|}{ JAN } \\
\hline $\begin{array}{l}18 \ldots \\
\operatorname{MAR}\end{array}$ & 1131 & 9.3 & 175 & 6.9 & 8.7 & 760 & 9.6 & 82 & 4.4 & 700 & 720 & 1050 & 1220 \\
\hline$\underset{\mathrm{MAY}}{20 \ldots}$ & 1255 & 25 & 538 & 7.3 & 14.2 & 767 & 8.3 & 80 & 3.9 & 575 & E34k & 340 & 320 \\
\hline $\begin{array}{l}15 \ldots \\
\text { JUL }\end{array}$ & 1119 & 16 & 695 & 7.4 & 23.3 & 763 & 5.1 & 59 & 2.6 & 213 & 400 & 300 & 340 \\
\hline $\begin{array}{l}10 \ldots \\
\operatorname{SEP}\end{array}$ & 1140 & 44 & 544 & 7.9 & 27.8 & 760 & 5.4 & 69 & 1.4 & 525 & 410 & 533 & 207 \\
\hline $17 \ldots$ & 1202 & 28 & 447 & 7.2 & 25.8 & 765 & 4.0 & 49 & 2.5 & $\mathrm{E} 280 \mathrm{k}$ & E340k & 650 & 900 \\
\hline Date & $\begin{array}{c}\text { Nitrate } \\
\text { water, } \\
\text { fltrd, } \\
\text { mg/L } \\
\text { as N } \\
(00618)\end{array}$ & $\begin{array}{c}\text { Nitrite } \\
\text { water, } \\
\text { fltrd, } \\
\mathrm{mg} / \mathrm{L} \\
\text { as N } \\
(00613)\end{array}$ & $\begin{array}{c}\text { Nitrite } \\
+ \\
\text { nitrate } \\
\text { water } \\
\text { unfltrd } \\
\mathrm{mg} / \mathrm{L} \\
\text { as } \mathrm{N} \\
(00630)\end{array}$ & $\begin{array}{c}\text { Ammonia } \\
\text { water, } \\
\text { fltrd, } \\
\mathrm{mg} / \mathrm{L} \\
\text { as N } \\
(00608)\end{array}$ & $\begin{array}{c}\text { Total } \\
\text { nitro- } \\
\text { gen, } \\
\text { water, } \\
\text { unfltrd } \\
\text { mg/L } \\
(00600)\end{array}$ & $\begin{array}{c}\text { Organic } \\
\text { nitro- } \\
\text { gen, } \\
\text { water, } \\
\text { unfltrd } \\
\text { mg/L } \\
(00605)\end{array}$ & $\begin{array}{c}\text { Organic } \\
\text { nitro- } \\
\text { gen, } \\
\text { water, } \\
\text { fltrd, } \\
\text { mg/L } \\
(00607)\end{array}$ & $\begin{array}{c}\text { Ammonia } \\
+ \\
\text { org-N, } \\
\text { water, } \\
\text { fltrd, } \\
\text { mg/L } \\
\text { as N } \\
(00623)\end{array}$ & $\begin{array}{c}\text { Ammonia } \\
+ \\
\text { org-N, } \\
\text { water, } \\
\text { unfltrd } \\
\text { mg/L } \\
\text { as N } \\
(00625)\end{array}$ & $\begin{array}{c}\text { Phos- } \\
\text { phorus, } \\
\text { water, } \\
\text { unfltrd } \\
\text { mg/L } \\
(00665)\end{array}$ & $\begin{array}{c}\text { Phos- } \\
\text { phorus, } \\
\text { water, } \\
\text { fltrd, } \\
\text { mg/L } \\
(00666)\end{array}$ & $\begin{array}{l}\text { Ortho- } \\
\text { phos- } \\
\text { phate, } \\
\text { water, } \\
\text { fltrd, } \\
\text { mg/L } \\
\text { as P } \\
(00671)\end{array}$ & $\begin{array}{c}\text { Ortho- } \\
\text { phos- } \\
\text { phate, } \\
\text { water, } \\
\text { fltrd, } \\
\text { mg/L } \\
(00660)\end{array}$ \\
\hline
\end{tabular}

\begin{tabular}{|c|c|c|c|c|c|c|c|c|c|c|c|c|c|}
\hline \multicolumn{14}{|l|}{ JAN } \\
\hline $18 \ldots$ & .22 & .006 & -- & E.04 & -- & -- & -- & .62 & -- & -- & .101 & .08 & .236 \\
\hline \multicolumn{14}{|l|}{ MAR } \\
\hline $20 \ldots$ & .22 & .064 & -- & .12 & 1.2 & .78 & 1.2 & 1.3 & .90 & .067 & .167 & .13 & .392 \\
\hline \multicolumn{14}{|l|}{ MAY } \\
\hline $15 \ldots$ & .37 & .025 & -- & .06 & 1.6 & 1.1 & .72 & .77 & 1.2 & .21 & .113 & .08 & .251 \\
\hline \multicolumn{14}{|l|}{ JUL } \\
\hline $10 \ldots$ & .26 & .008 & .273 & .04 & 1.0 & .68 & .49 & .53 & .73 & .039 & .086 & .07 & .218 \\
\hline \multicolumn{14}{|l|}{ SEP } \\
\hline $17 \ldots$ & .45 & .052 & .530 & .09 & 1.6 & .99 & 1.0 & 1.1 & 1.1 & .26 & .188 & .14 & .420 \\
\hline
\end{tabular}

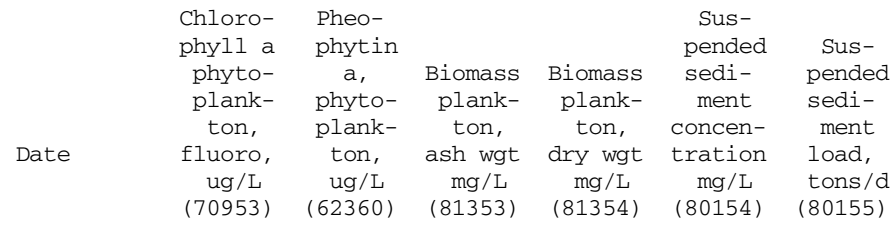

$\begin{array}{lllllll}\text { JAN } \\ \begin{array}{l}18 \ldots \\ \text { MAR }\end{array} & 5.0 & 6.4 & 942 & 961 & 104 & 2.6 \\ \quad 20 \ldots & 3.5 & 8.3 & 987 & 1020 & 105 & 7.1 \\ \begin{array}{l}\text { MAY } \\ 15 \ldots\end{array} & 3.8 & 5.6 & 690 & 697 & 66 & 2.8 \\ \begin{array}{l}\text { JUL } \\ 10 \ldots\end{array} & 2.1 & 3.2 & 344 & 352 & 66 & 7.8 \\ \begin{array}{l}\text { SEP } \\ 17 \ldots\end{array} & 1.9 & 2.9 & 334 & 342 & 67 & 5.1\end{array}$


Table 6. Periodically collected water-quality properties and constituents at six sites in the San Bernard River, January 2001-August 2002-Continued

293123096073001 Gum Tree Branch at CR 252, nr East Bernard, TX-Continued WATER-QUALITY DATA, WATER YEAR OCTOBER 2001 TO SEPTEMBER 2002

\begin{tabular}{|c|c|c|c|c|c|c|c|c|c|c|c|c|c|}
\hline Date & Time & $\begin{array}{c}\text { Instan- } \\
\text { taneous } \\
\text { dis- } \\
\text { charge, } \\
\text { cfs } \\
(00061)\end{array}$ & $\begin{array}{c}\text { Specif. } \\
\text { conduc- } \\
\text { tance, } \\
\text { wat unf } \\
\text { uS/cm } \\
25 \text { degc } \\
(00095)\end{array}$ & $\begin{array}{c}\text { pH, } \\
\text { water, } \\
\text { unfltrd } \\
\text { field, } \\
\text { std } \\
\text { units } \\
(00400)\end{array}$ & $\begin{array}{c}\text { Temper- } \\
\text { ature, } \\
\text { water, } \\
\text { deg C } \\
(00010)\end{array}$ & $\begin{array}{l}\text { Baro- } \\
\text { metric } \\
\text { pres- } \\
\text { sure, } \\
\text { mm Hg } \\
(00025)\end{array}$ & $\begin{array}{c}\text { Dis- } \\
\text { solved } \\
\text { oxygen, } \\
\text { mg/L } \\
(00300)\end{array}$ & $\begin{array}{c}\text { Dis- } \\
\text { solved } \\
\text { oxygen, } \\
\text { percent } \\
\text { of sat- } \\
\text { uration } \\
\text { (00301) }\end{array}$ & $\begin{array}{c}\text { BOD, } \\
\text { water, } \\
\text { unfltrd } \\
5 \text { day, } \\
20 \text { degC } \\
\mathrm{mg} / \mathrm{L} \\
(00310)\end{array}$ & $\begin{array}{c}\text { Fecal } \\
\text { coli- } \\
\text { form, } \\
\text { M-FC } \\
0.7 \mathrm{u} \mathrm{MF} \\
\mathrm{Col} / \\
100 \mathrm{~mL} \\
(31625)\end{array}$ & $\begin{array}{c}\text { E coli, } \\
\text { m-TEC } \\
\text { MF, } \\
\text { water, } \\
\text { col/ } \\
100 \mathrm{~mL} \\
(31633)\end{array}$ & $\begin{array}{c}\text { Fecal } \\
\text { strep- } \\
\text { tococci } \\
\text { KF } \\
\text { MF' } \\
\text { Col/ } \\
100 \mathrm{~mL} \\
(31673)\end{array}$ & $\begin{array}{c}\text { Entero- } \\
\text { Cocci, } \\
\text { m-E } \\
\text { MF, } \\
\text { water, } \\
\text { col/ } \\
100 \mathrm{~mL} \\
(31649)\end{array}$ \\
\hline NOV & & & & & & & & & & & & & \\
\hline$\underset{\text { JAN }}{13} \ldots$ & 1240 & 8.2 & 1620 & 7.6 & 19.7 & 760 & 4.9 & 54 & 1.0 & 120 & 210 & 140 & 108 \\
\hline$\underset{\operatorname{MAR}}{29 \ldots}$ & 1330 & 6.8 & 1640 & 7.6 & 19.6 & 758 & 7.1 & 78 & 1.1 & 147 & 170 & 193 & 213 \\
\hline$\underset{\text { IAY }}{12 \ldots}$ & 1446 & 6.8 & 1700 & 7.7 & 18.5 & 760 & 8.0 & 86 & 1.7 & 167 & 84 & 68 & -- \\
\hline$\underset{\text { UG }}{29} \ldots$ & 1152 & 12 & 759 & 7.7 & 25.2 & 759 & 6.7 & 82 & 4.0 & 200 & 84 & 236 & -- \\
\hline $28 \ldots$ & 1001 & 8.7 & 454 & 7.4 & 26.8 & 764 & 4.7 & 59 & 5.5 & 1000 & 620 & -- & 4200 \\
\hline Date & $\begin{array}{c}\text { Nitrate } \\
\text { water, } \\
\text { fltrd, } \\
\mathrm{mg} / \mathrm{L} \\
\text { as N } \\
(00618)\end{array}$ & $\begin{array}{c}\text { Nitrite } \\
\text { water, } \\
\text { fltrd, } \\
\text { mg/L } \\
\text { as N } \\
(00613)\end{array}$ & $\begin{array}{c}\text { Nitrite } \\
+ \\
\text { nitrate } \\
\text { water } \\
\text { unfltrd } \\
\text { mg/L } \\
\text { as N } \\
(00630)\end{array}$ & $\begin{array}{c}\text { Ammonia } \\
\text { water, } \\
\text { fltrd, } \\
\mathrm{mg} / \mathrm{L} \\
\text { as N } \\
(00608)\end{array}$ & $\begin{array}{c}\text { Total } \\
\text { nitro- } \\
\text { gen, } \\
\text { water, } \\
\text { unfltrd } \\
\text { mg/L } \\
(00600)\end{array}$ & $\begin{array}{c}\text { Organic } \\
\text { nitro- } \\
\text { gen, } \\
\text { water, } \\
\text { unfltrd } \\
\text { mg/L } \\
(00605)\end{array}$ & $\begin{array}{c}\text { Organic } \\
\text { nitro- } \\
\text { gen, } \\
\text { water, } \\
\text { fltrd, } \\
\text { mg/L } \\
(00607)\end{array}$ & $\begin{array}{c}\text { Ammonia } \\
+ \\
\text { org-N, } \\
\text { water, } \\
\text { fltrd, } \\
\text { mg/L } \\
\text { as N } \\
(00623)\end{array}$ & $\begin{array}{c}\text { Ammonia } \\
+ \\
\text { org-N, } \\
\text { water, } \\
\text { unfltrd } \\
\text { mg/L } \\
\text { as } N \\
(00625)\end{array}$ & $\begin{array}{c}\text { Phos- } \\
\text { phorus, } \\
\text { water, } \\
\text { unfltrd } \\
\text { mg/L } \\
(00665)\end{array}$ & $\begin{array}{c}\text { Phos- } \\
\text { phorus, } \\
\text { water, } \\
\text { fltrd, } \\
\text { mg/L } \\
(00666)\end{array}$ & $\begin{array}{l}\text { Ortho- } \\
\text { phos- } \\
\text { phate, } \\
\text { water, } \\
\text { fltrd, } \\
\text { mg/L } \\
\text { as P } \\
(00671)\end{array}$ & $\begin{array}{l}\text { Ortho- } \\
\text { phos- } \\
\text { phate, } \\
\text { water, } \\
\text { fltrd, } \\
\text { mg/L } \\
(00660)\end{array}$ \\
\hline
\end{tabular}

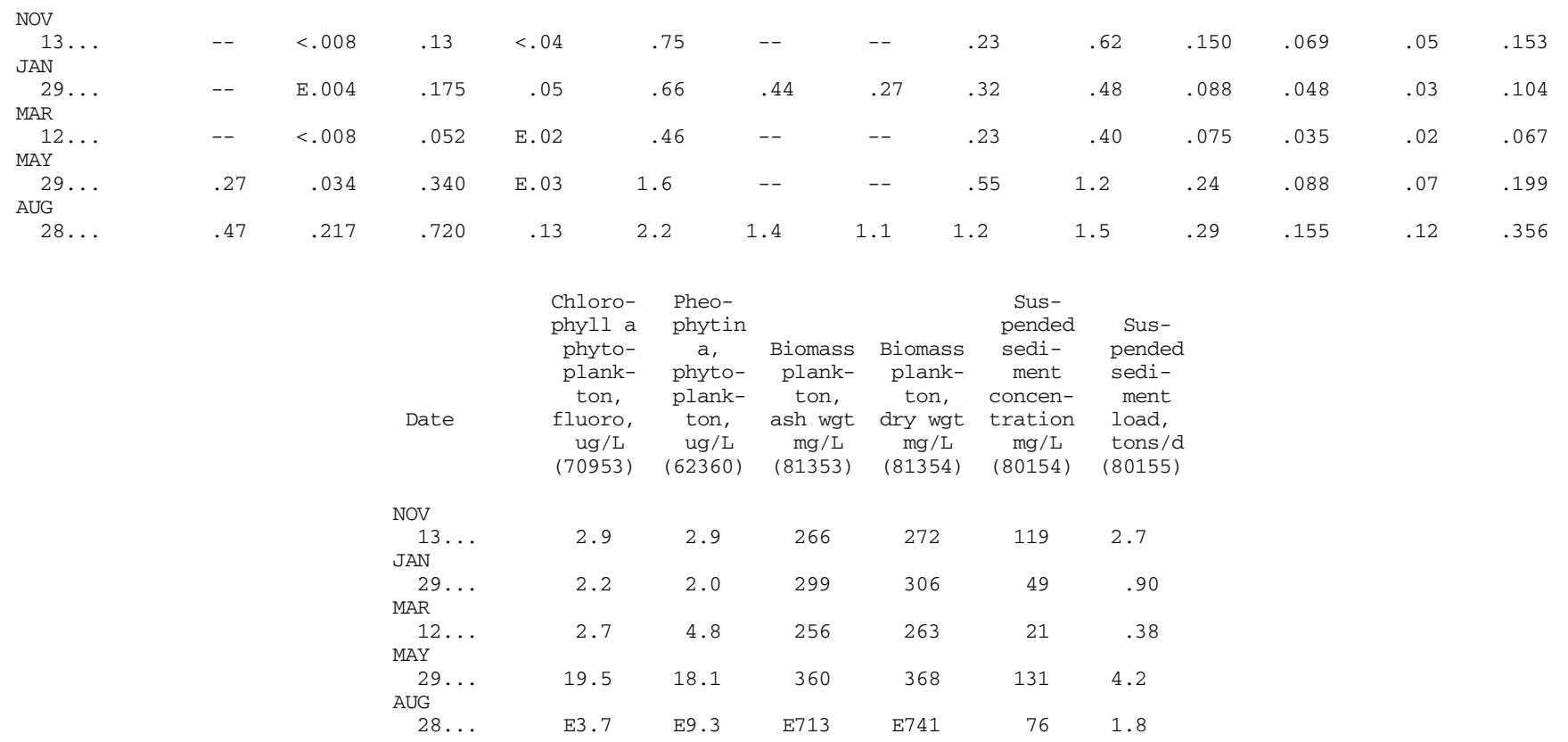

Remark codes used in this report:

$<--$ Less than

E -- Estimated value

Value qualifier codes used in this report:

k -- Counts outside acceptable range 
Table 6. Periodically collected water-quality properties and constituents at six sites in the San Bernard River, January 2001-August 2002-Continued

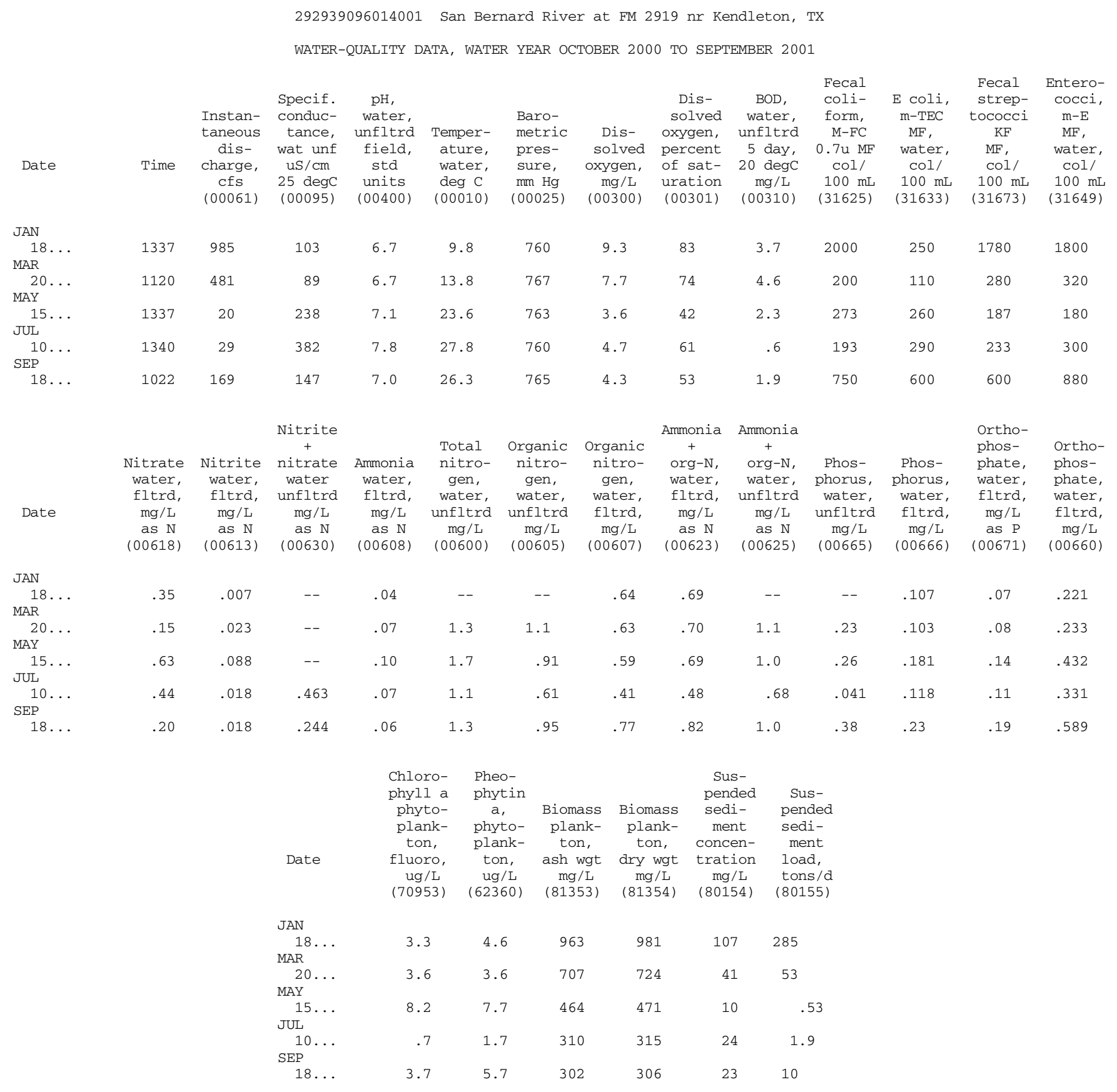


Table 6. Periodically collected water-quality properties and constituents at six sites in the San Bernard River, January 2001-August 2002-Continued

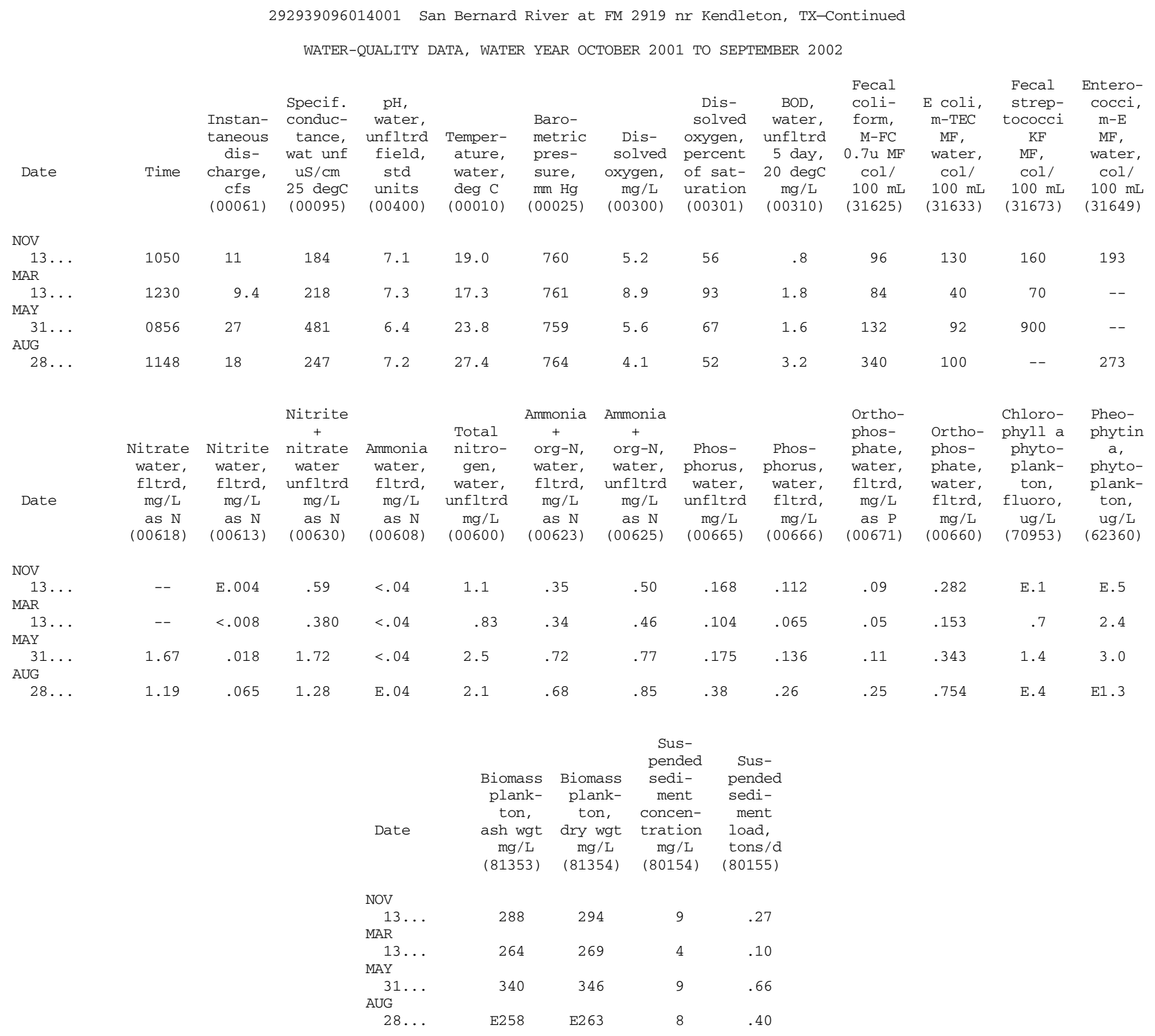

Remark codes used in this report:

$<--$ Less than

E -- Estimated value 
Table 6. Periodically collected water-quality properties and constituents at six sites in the San Bernard River, January 2001-August 2002-Continued

08117500 San Bernard River nr Boling, TX

WATER-QUALITY DATA, WATER YEAR OCTOBER 2000 TO SEPTEMBER 2001

\begin{tabular}{|c|c|c|c|c|c|c|c|c|c|c|c|c|c|}
\hline Date & Time & $\begin{array}{c}\text { Instan- } \\
\text { taneous } \\
\text { dis- } \\
\text { charge, } \\
\text { cfs } \\
(00061)\end{array}$ & $\begin{array}{c}\text { Specif. } \\
\text { conduc- } \\
\text { tance, } \\
\text { wat unf } \\
\text { uS/cm } \\
25 \text { degc } \\
(00095)\end{array}$ & $\begin{array}{c}\text { pH, } \\
\text { water, } \\
\text { unfltrd } \\
\text { field, } \\
\text { std } \\
\text { units } \\
(00400)\end{array}$ & $\begin{array}{c}\text { Temper- } \\
\text { ature, } \\
\text { water, } \\
\text { deg C } \\
(00010)\end{array}$ & $\begin{array}{l}\text { Baro- } \\
\text { metric } \\
\text { pres- } \\
\text { sure, } \\
\text { mm Hg } \\
(00025)\end{array}$ & $\begin{array}{c}\text { Dis- } \\
\text { solved } \\
\text { oxygen, } \\
\text { mg/L } \\
(00300)\end{array}$ & $\begin{array}{l}\text { Dis- } \\
\text { solved } \\
\text { oxygen, } \\
\text { percent } \\
\text { of sat- } \\
\text { uration } \\
\text { (00301) }\end{array}$ & $\begin{array}{c}\text { BOD, } \\
\text { water, } \\
\text { unfltrd } \\
5 \text { day, } \\
20 \text { degC } \\
\mathrm{mg} / \mathrm{L} \\
(00310)\end{array}$ & $\begin{array}{c}\text { Fecal } \\
\text { coli- } \\
\text { form, } \\
\text { M-FC } \\
0.7 \mathrm{u} \mathrm{MF} \\
\mathrm{Col} / \\
100 \mathrm{~mL} \\
(31625)\end{array}$ & $\begin{array}{c}\text { E coli, } \\
\text { m-TEC } \\
\text { MF, } \\
\text { water, } \\
\text { col/ } \\
100 \mathrm{~mL} \\
(31633)\end{array}$ & $\begin{array}{c}\text { Fecal } \\
\text { strep- } \\
\text { tococci } \\
\text { KF } \\
\text { MF, } \\
\text { col/ } \\
100 \mathrm{~mL} \\
(31673)\end{array}$ & $\begin{array}{c}\text { Entero- } \\
\text { cocci, } \\
\text { m-E } \\
\text { MF, } \\
\text { water, } \\
\text { col/ } \\
100 \mathrm{~mL} \\
\text { (31649) }\end{array}$ \\
\hline JAN & & & & & & & & & & & & & \\
\hline $\begin{array}{c}19 \ldots \\
\operatorname{MAR}\end{array}$ & 1242 & 2190 & 155 & 7.3 & 8.2 & 769 & 10.2 & 86 & 2.4 & 2300 & 680 & 4400 & 5400 \\
\hline$\underset{\text { MAY }}{21} \ldots$ & 1246 & 1060 & 102 & 7.2 & 14.8 & 770 & 7.0 & 69 & 2.0 & 800 & 240 & 925 & 800 \\
\hline $\begin{array}{l}16 \ldots \\
\text { JUL }\end{array}$ & 1226 & 116 & 350 & 7.7 & 24.1 & 763 & 6.9 & 82 & 1.6 & 140 & 240 & 233 & 750 \\
\hline $\operatorname{SEP}^{11 \ldots}$ & 1545 & 95 & 493 & 7.8 & 29.2 & 760 & 6.3 & 83 & 1.2 & 56 & 140 & 510 & 474 \\
\hline $19 \ldots$ & 1143 & 522 & 167 & 7.2 & 26.5 & 764 & 4.4 & 55 & 1.1 & $\mathrm{E} 240 \mathrm{k}$ & -- & 575 & 750 \\
\hline Date & $\begin{array}{c}\text { Nitrate } \\
\text { water, } \\
\text { fltrd, } \\
\text { mg/L } \\
\text { as N } \\
(00618)\end{array}$ & $\begin{array}{c}\text { Nitrite } \\
\text { water, } \\
\text { fltrd, } \\
\mathrm{mg} / \mathrm{L} \\
\text { as N } \\
(00613)\end{array}$ & $\begin{array}{c}\text { Nitrite } \\
+ \\
\text { nitrate } \\
\text { water } \\
\text { unfltrd } \\
\mathrm{mg} / \mathrm{L} \\
\text { as } \mathrm{N} \\
(00630)\end{array}$ & $\begin{array}{c}\text { Ammonia } \\
\text { water, } \\
\text { fltrd, } \\
\mathrm{mg} / \mathrm{L} \\
\text { as N } \\
(00608)\end{array}$ & $\begin{array}{c}\text { Total } \\
\text { nitro- } \\
\text { gen, } \\
\text { water, } \\
\text { unfltrd } \\
\text { mg/L } \\
(00600)\end{array}$ & $\begin{array}{c}\text { Organic } \\
\text { nitro- } \\
\text { gen, } \\
\text { water, } \\
\text { unfltrd } \\
\text { mg/L } \\
(00605)\end{array}$ & $\begin{array}{c}\text { Organic } \\
\text { nitro- } \\
\text { gen, } \\
\text { water, } \\
\text { fltrd, } \\
\text { mg/L } \\
(00607)\end{array}$ & $\begin{array}{c}\text { Ammonia } \\
+ \\
\text { org-N, } \\
\text { water, } \\
\text { fltrd, } \\
\text { mg/L } \\
\text { as N } \\
(00623)\end{array}$ & $\begin{array}{c}\text { Ammonia } \\
+ \\
\text { org-N, } \\
\text { water, } \\
\text { unfltrd } \\
\text { mg/L } \\
\text { as N } \\
(00625)\end{array}$ & $\begin{array}{c}\text { Phos- } \\
\text { phorus, } \\
\text { water, } \\
\text { unfltrd } \\
\text { mg/L } \\
(00665)\end{array}$ & $\begin{array}{c}\text { Phos- } \\
\text { phorus, } \\
\text { water, } \\
\text { fltrd, } \\
\text { mg/L } \\
(00666)\end{array}$ & $\begin{array}{l}\text { Ortho- } \\
\text { phos- } \\
\text { phate, } \\
\text { water, } \\
\text { fltrd, } \\
\text { mg/L } \\
\text { as P } \\
(00671)\end{array}$ & $\begin{array}{c}\text { Ortho- } \\
\text { phos- } \\
\text { phate, } \\
\text { water, } \\
\text { fltrd, } \\
\text { mg/L } \\
(00660)\end{array}$ \\
\hline
\end{tabular}

\begin{tabular}{|c|c|c|c|c|c|c|c|c|c|c|c|c|c|}
\hline \multicolumn{14}{|l|}{ JAN } \\
\hline $19 \ldots$ & .51 & .007 & -- & .04 & 1.9 & 1.4 & .62 & .67 & 1.4 & .105 & .171 & .13 & .399 \\
\hline \multicolumn{14}{|l|}{ MAR } \\
\hline $21 \ldots$ & .19 & .009 & -- & E.03 & 1.3 & -- & -- & .66 & 1.1 & -- & .108 & .08 & .258 \\
\hline \multicolumn{14}{|l|}{ MAY } \\
\hline $16 \ldots$ & .82 & .024 & -- & $<.04$ & 1.9 & -- & -- & .67 & 1.1 & .29 & .188 & .16 & .484 \\
\hline \multicolumn{14}{|l|}{ JUL } \\
\hline $11 \ldots$ & -- & E.005 & .305 & $<.04$ & .99 & -- & -- & .44 & .69 & .058 & .120 & .10 & .300 \\
\hline \multicolumn{14}{|l|}{ SEP } \\
\hline $19 \ldots$ & -- & .011 & .245 & .04 & 1.1 & .85 & .78 & .82 & .89 & .45 & 40 & 32 & .993 \\
\hline
\end{tabular}

\begin{tabular}{|c|c|c|c|c|c|c|}
\hline Date & $\begin{array}{c}\text { Chloro- } \\
\text { phyll a } \\
\text { phyto- } \\
\text { plank- } \\
\text { ton, } \\
\text { fluoro, } \\
\text { ug/L } \\
\text { (70953) }\end{array}$ & $\begin{array}{c}\text { Pheo- } \\
\text { phytin } \\
\text { a, } \\
\text { phyto- } \\
\text { plank- } \\
\text { ton, } \\
\text { ug/L } \\
(62360)\end{array}$ & $\begin{array}{c}\text { Biomass } \\
\text { plank- } \\
\text { ton, } \\
\text { ash wgt } \\
\mathrm{mg} / \mathrm{L} \\
(81353)\end{array}$ & $\begin{array}{c}\text { Biomass } \\
\text { plank- } \\
\text { ton, } \\
\text { dry wgt } \\
\text { mg/L } \\
(81354)\end{array}$ & $\begin{array}{c}\text { Sus- } \\
\text { pended } \\
\text { sedi- } \\
\text { ment } \\
\text { concen- } \\
\text { tration } \\
\text { mg/L } \\
\text { (80154) }\end{array}$ & $\begin{array}{c}\text { Sus- } \\
\text { pended } \\
\text { sedi- } \\
\text { ment } \\
\text { load, } \\
\text { tons/d } \\
\text { (80155) }\end{array}$ \\
\hline JAN & & & & & & \\
\hline$\underset{\operatorname{MAR}}{19}$ & 2.0 & 8.0 & 1470 & 1500 & 192 & 1140 \\
\hline$\underset{\text { MAY }}{21 \ldots}$ & 3.4 & 4.5 & 1390 & 1420 & 62 & 177 \\
\hline $16 \ldots$ & 1.9 & 4.2 & 736 & 749 & 62 & 19 \\
\hline $11 \ldots$ & 3.0 & 3.2 & 303 & 310 & 60 & 15 \\
\hline $\begin{array}{l}\text { SEP } \\
19 \ldots\end{array}$ & 1.2 & 1.9 & 457 & 467 & 46 & 65 \\
\hline
\end{tabular}


Table 6. Periodically collected water-quality properties and constituents at six sites in the San Bernard River, January 2001-August 2002-Continued

08117500 San Bernard River nr Boling, TX-Continued

WATER-QUALITY DATA, WATER YEAR OCTOBER 2001 TO SEPTEMBER 2002

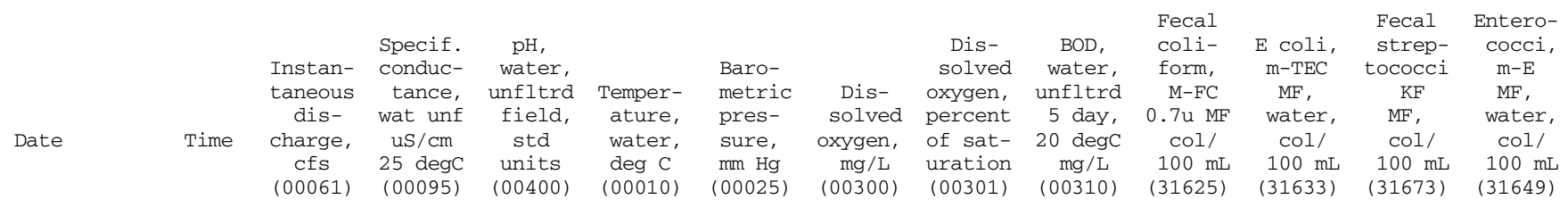

\begin{tabular}{|c|c|c|c|c|c|c|c|c|c|c|c|c|c|}
\hline \multicolumn{14}{|l|}{ NOV } \\
\hline$\underset{\text { JAN }}{14 \ldots}$ & 1328 & 28 & 568 & 7.7 & 20.2 & 760 & 6.2 & 68 & 1.0 & 100 & 230 & 193 & 80 \\
\hline $30 \ldots$ & 1209 & 67 & 492 & 7.7 & 18.9 & 761 & 7.8 & 84 & .9 & 133 & 80 & 108 & 153 \\
\hline MAR & & & & & & & & & & & & & \\
\hline$\underset{\text { MAY }}{13 \ldots}$ & 1418 & 24 & 848 & 8.1 & 18.6 & 761 & 10.2 & 110 & 3.8 & 147 & 48 & 40 & -- \\
\hline $\begin{array}{c}31 \ldots \\
\text { AUG }\end{array}$ & 1027 & 90 & 598 & 6.8 & 24.3 & 759 & 6.6 & 79 & 1.8 & 160 & 88 & 240 & -- \\
\hline $29 \ldots$ & 1032 & 98 & 294 & 7.5 & 28.1 & 765 & 4.9 & 62 & 2.5 & 56 & 350 & -- & 160 \\
\hline Date & $\begin{array}{c}\text { Nitrate } \\
\text { water, } \\
\text { fltrd, } \\
\text { mg/L } \\
\text { as N } \\
(00618)\end{array}$ & $\begin{array}{c}\text { Nitrite } \\
\text { water, } \\
\text { fltrd, } \\
\text { mg/L } \\
\text { as N } \\
(00613)\end{array}$ & $\begin{array}{c}\text { Nitrite } \\
+ \\
\text { nitrate } \\
\text { water } \\
\text { unfltrd } \\
\mathrm{mg} / \mathrm{L} \\
\text { as } \mathrm{N} \\
(00630)\end{array}$ & $\begin{array}{c}\text { Ammonia } \\
\text { water, } \\
\text { fltrd, } \\
\text { mg/L } \\
\text { as N } \\
(00608)\end{array}$ & $\begin{array}{c}\text { Total } \\
\text { nitro- } \\
\text { gen, } \\
\text { water, } \\
\text { unfltrd } \\
\text { mg/L } \\
(00600)\end{array}$ & $\begin{array}{c}\text { Organic } \\
\text { nitro- } \\
\text { gen, } \\
\text { water, } \\
\text { unfltrd } \\
\text { mg/L } \\
(00605)\end{array}$ & $\begin{array}{c}\text { Organic } \\
\text { nitro- } \\
\text { gen, } \\
\text { water, } \\
\text { fltrd, } \\
\text { mg/L } \\
(00607)\end{array}$ & $\begin{array}{c}\text { Ammonia } \\
+ \\
\text { org-N, } \\
\text { water, } \\
\text { fltrd, } \\
\text { mg/L } \\
\text { as N } \\
(00623)\end{array}$ & $\begin{array}{c}\text { Ammonia } \\
+ \\
\text { org-N, } \\
\text { water, } \\
\text { unfltrd } \\
\text { mg/L } \\
\text { as N } \\
(00625)\end{array}$ & $\begin{array}{c}\text { Phos- } \\
\text { phorus, } \\
\text { water, } \\
\text { unfltrd } \\
\text { mg/L } \\
(00665)\end{array}$ & $\begin{array}{c}\text { Phos- } \\
\text { phorus, } \\
\text { water, } \\
\text { fltrd, } \\
\text { mg/L } \\
(00666)\end{array}$ & $\begin{array}{l}\text { Ortho- } \\
\text { phos- } \\
\text { phate, } \\
\text { water, } \\
\text { fltrd, } \\
\text { mg/L } \\
\text { as P } \\
(00671)\end{array}$ & $\begin{array}{c}\text { Ortho- } \\
\text { phos- } \\
\text { phate, } \\
\text { water, } \\
\text { fltrd, } \\
\text { mg/L } \\
(00660)\end{array}$ \\
\hline
\end{tabular}

\begin{tabular}{|c|c|c|c|c|c|c|c|c|c|c|c|c|c|}
\hline \multicolumn{14}{|l|}{ NOV } \\
\hline $14 \ldots$ & -- & $<.008$ & $<.10$ & $<.04$ & .57 & -- & -- & .40 & .50 & .160 & .121 & .10 & .313 \\
\hline \multicolumn{14}{|l|}{ JAN } \\
\hline $30 \ldots$ & -- & $<.008$ & -- & E.03 & .92 & -- & -- & .40 & .53 & .109 & .061 & .04 & .138 \\
\hline \multicolumn{14}{|l|}{ MAR } \\
\hline $13 \ldots$ & .35 & .041 & .425 & .75 & 2.5 & 1.3 & .75 & 1.5 & 2.0 & .21 & .130 & .10 & .300 \\
\hline \multicolumn{14}{|l|}{ MAY } \\
\hline $31 \ldots$ & -- & E.005 & 1.29 & $<.04$ & 2.1 & -- & -- & .65 & .78 & .150 & .101 & .08 & .245 \\
\hline \multicolumn{14}{|l|}{ AUG } \\
\hline $29 .$. & .61 & .091 & .715 & E.03 & 1.9 & -- & -- & .94 & 1.2 & .35 & .24 & .22 & .671 \\
\hline
\end{tabular}

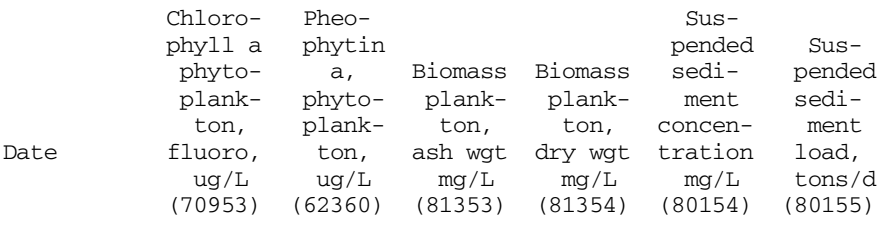

\begin{tabular}{|c|c|c|c|c|c|c|}
\hline \multicolumn{7}{|l|}{ NOV } \\
\hline $14 \ldots$ & .8 & 1.1 & 278 & 284 & 15 & 1.1 \\
\hline \multicolumn{7}{|l|}{ JAN } \\
\hline $30 \ldots$ & 1.4 & 1.6 & 320 & 327 & 39 & 7.1 \\
\hline \multicolumn{7}{|l|}{ MAR } \\
\hline $13 \ldots$ & 34.1 & 15.6 & 464 & 477 & 31 & 2.0 \\
\hline \multicolumn{7}{|l|}{ MAY } \\
\hline $31 \ldots$ & 3.7 & 4.6 & 352 & 360 & 43 & 10 \\
\hline \multicolumn{7}{|l|}{ AUG } \\
\hline $29 \ldots$ & $\mathrm{E} 1.1$ & E1.7 & E484 & E496 & 42 & 11 \\
\hline
\end{tabular}

Remark codes used in this report:

$<--$ Less than

E -- Estimated value

Value qualifier codes used in this report:

k -- Counts outside acceptable range 
Table 6. Periodically collected water-quality properties and constituents at six sites in the San Bernard River, January 2001-August 2002-Continued

290935095455601 San Bernard River at FM 1301 nr East Columbia, TX

WATER-QUALITY DATA，WATER YEAR OCTOBER 2000 TO SEPTEMBER 2001

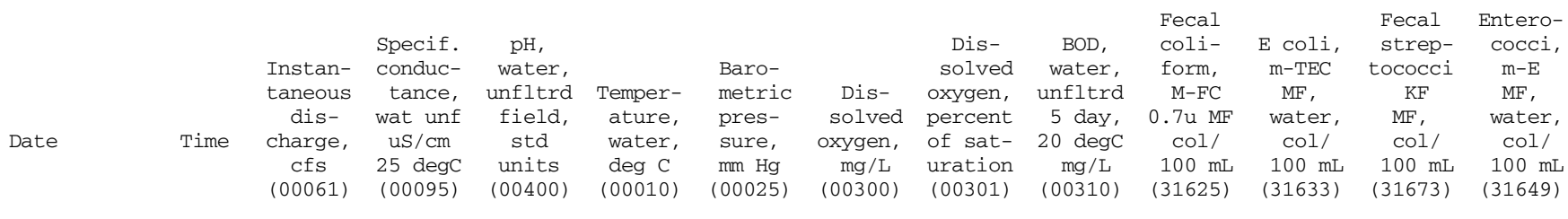

\begin{tabular}{|c|c|c|c|c|c|c|c|c|c|c|c|c|c|}
\hline JAN & & & & & & & & & & & & & \\
\hline $\begin{array}{c}19 \ldots \\
\operatorname{MAR}\end{array}$ & 1428 & 2510 & 181 & 7.6 & 8.7 & 769 & 10.4 & 89 & 2.4 & 775 & 250 & 2060 & 2200 \\
\hline$\underset{\text { MAY }}{21 \ldots}$ & 1110 & 1380 & 107 & 7.4 & 14.0 & 765 & 7.6 & 73 & 2.0 & 600 & 210 & 260 & 373 \\
\hline $16 \ldots$ & 1115 & 174 & 223 & 7.6 & 23.4 & 763 & 6.9 & 81 & 2.2 & 500 & 150 & 400 & 280 \\
\hline JUL & & & & & & & & & & & & & \\
\hline $\begin{array}{l}11 \ldots \\
\operatorname{SEP}\end{array}$ & 1350 & 59 & 648 & 7.8 & 28.4 & 760 & 8.3 & 107 & 1.6 & 147 & 210 & 333 & 437 \\
\hline $19 \ldots$ & 1041 & 684 & 160 & 7.3 & 26.1 & 764 & 5.4 & 67 & 1.8 & 160 & 2900 & 525 & 500 \\
\hline Date & $\begin{array}{c}\text { Nitrate } \\
\text { water, } \\
\text { fltrd, } \\
\text { mg/L } \\
\text { as N } \\
(00618)\end{array}$ & $\begin{array}{c}\text { Nitrite } \\
\text { water, } \\
\text { fltrd, } \\
\text { mg/L } \\
\text { as N } \\
(00613)\end{array}$ & $\begin{array}{c}\text { Nitrite } \\
+ \\
\text { nitrate } \\
\text { water } \\
\text { unfltrd } \\
\mathrm{mg} / \mathrm{L} \\
\text { as } \mathrm{N} \\
(00630)\end{array}$ & $\begin{array}{c}\text { Ammonia } \\
\text { water, } \\
\text { fltrd, } \\
\text { mg/L } \\
\text { as N } \\
(00608)\end{array}$ & $\begin{array}{c}\text { Total } \\
\text { nitro- } \\
\text { gen, } \\
\text { water, } \\
\text { unfltrd } \\
\text { mg/L } \\
(00600)\end{array}$ & $\begin{array}{c}\text { Organic } \\
\text { nitro- } \\
\text { gen, } \\
\text { water, } \\
\text { unfltrd } \\
\text { mg/L } \\
(00605)\end{array}$ & $\begin{array}{c}\text { Organic } \\
\text { nitro- } \\
\text { gen, } \\
\text { water, } \\
\text { fltrd, } \\
\text { mg/L } \\
(00607)\end{array}$ & $\begin{array}{c}\text { Ammonia } \\
+ \\
\text { org-N, } \\
\text { water, } \\
\text { fltrd, } \\
\text { mg/L } \\
\text { as N } \\
(00623)\end{array}$ & $\begin{array}{c}\text { Ammonia } \\
+ \\
\text { org-N, } \\
\text { water, } \\
\text { unfltrd } \\
\text { mg/L } \\
\text { as N } \\
(00625)\end{array}$ & $\begin{array}{c}\text { Phos- } \\
\text { phorus, } \\
\text { water, } \\
\text { unfltrd } \\
\text { mg/L } \\
(00665)\end{array}$ & $\begin{array}{c}\text { Phos- } \\
\text { phorus, } \\
\text { water, } \\
\text { fltrd, } \\
\text { mg/L } \\
(00666)\end{array}$ & $\begin{array}{l}\text { Ortho- } \\
\text { phos- } \\
\text { phate, } \\
\text { water, } \\
\text { fltrd, } \\
\text { mg/L } \\
\text { as P } \\
(00671)\end{array}$ & $\begin{array}{c}\text { Ortho- } \\
\text { phos- } \\
\text { phate, } \\
\text { water, } \\
\text { fltrd, } \\
\text { mg/L } \\
(00660)\end{array}$ \\
\hline
\end{tabular}

\begin{tabular}{|c|c|c|c|c|c|c|c|c|c|c|c|c|c|}
\hline \multicolumn{14}{|l|}{ JAN } \\
\hline $19 \ldots$ & .46 & .007 & -- & E.03 & 1.9 & -- & -- & .64 & 1.4 & .116 & .136 & .10 & .319 \\
\hline \multicolumn{14}{|l|}{ MAR } \\
\hline $21 \ldots$ & .19 & .010 & -- & E.03 & 1.3 & -- & -- & .65 & 1.1 & .24 & .112 & .09 & .273 \\
\hline \multicolumn{14}{|l|}{ MAY } \\
\hline $16 \ldots$ & 1.26 & .064 & -- & E.04 & 2.5 & -- & -- & .73 & 1.2 & .38 & .23 & .25 & .760 \\
\hline \multicolumn{14}{|l|}{ JUL } \\
\hline $11 \ldots$ & -- & E.005 & .297 & $<.04$ & 1.1 & -- & -- & .40 & .76 & .042 & .106 & .09 & .273 \\
\hline \multicolumn{14}{|l|}{ SEP } \\
\hline $19 \ldots$ & .24 & .007 & .253 & .05 & 1.1 & .80 & .82 & .88 & .85 & .40 & .38 & 29 & .883 \\
\hline
\end{tabular}

\begin{tabular}{|c|c|c|c|c|c|c|}
\hline Date & $\begin{array}{c}\text { Chloro- } \\
\text { phyll a } \\
\text { phyto- } \\
\text { plank- } \\
\text { ton, } \\
\text { fluoro, } \\
\text { ug/L } \\
\text { (70953) }\end{array}$ & $\begin{array}{c}\text { Pheo- } \\
\text { phytin } \\
\text { a, } \\
\text { phyto- } \\
\text { plank- } \\
\text { ton, } \\
\text { ug/L } \\
\text { (62360) }\end{array}$ & $\begin{array}{c}\text { Biomass } \\
\text { plank- } \\
\text { ton, } \\
\text { ash wgt } \\
\mathrm{mg} / \mathrm{L} \\
(81353)\end{array}$ & $\begin{array}{c}\text { Biomass } \\
\text { plank- } \\
\text { ton, } \\
\text { dry wgt } \\
\text { mg/L } \\
(81354)\end{array}$ & $\begin{array}{c}\text { Sus- } \\
\text { pended } \\
\text { sedi- } \\
\text { ment } \\
\text { concen- } \\
\text { tration } \\
\text { mg/L } \\
\text { (80154) }\end{array}$ & $\begin{array}{c}\text { Sus- } \\
\text { pended } \\
\text { sedi- } \\
\text { ment } \\
\text { load, } \\
\text { tons / d } \\
(80155)\end{array}$ \\
\hline JAN & & & & & & \\
\hline$\underset{\operatorname{MAR}}{19 \ldots}$ & 1.8 & 7.8 & 1450 & 1480 & 218 & 1480 \\
\hline$\underset{\text { MAY }}{21 \ldots}$ & 3.2 & 4.6 & -- & -- & 65 & 242 \\
\hline JUL $^{16 \ldots}$ & 1.2 & 4.7 & 939 & 957 & 141 & 66 \\
\hline$\underset{\operatorname{SEP}}{11} \ldots$ & 3.4 & 1.6 & 313 & 318 & 44 & 7.0 \\
\hline $19 \ldots$ & 6.2 & 3.1 & 457 & 466 & 51 & 94 \\
\hline
\end{tabular}


Table 6. Periodically collected water-quality properties and constituents at six sites in the San Bernard River, January 2001-August 2002-Continued

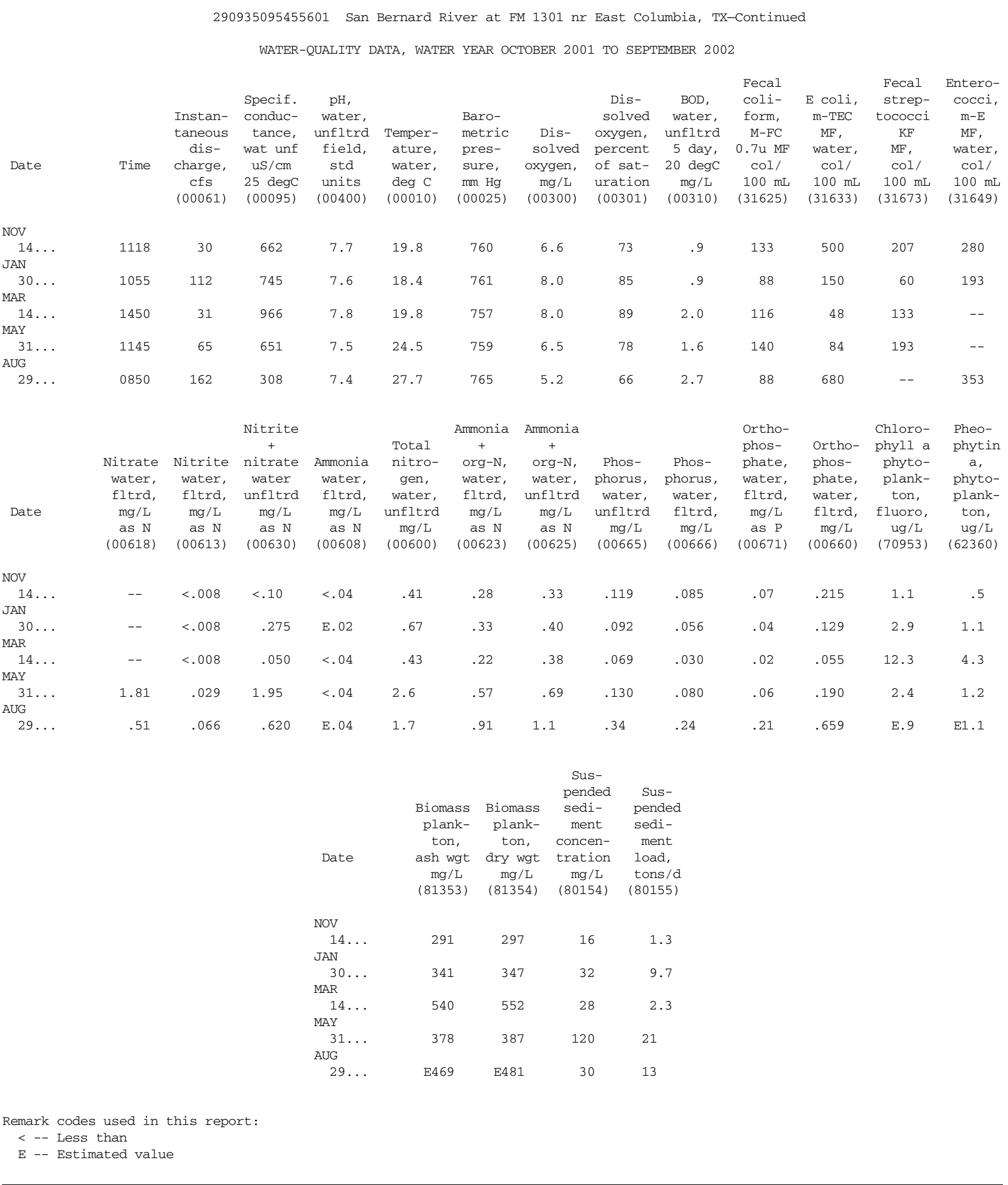


Table 8. Fish species collected in Dickinson Bayou, Texas Gulf Coastal Plain, 2000-2001

[Modified from Hogan (2002, table 3)]

\begin{tabular}{|c|c|c|c|c|c|}
\hline & \multicolumn{5}{|c|}{ Sampling site } \\
\hline & DCK01 & DCK02 & DCK03 & DCK04 & DCK05 \\
\hline \multicolumn{6}{|c|}{ Freshwater fish species } \\
\hline \multicolumn{6}{|l|}{ Alligator gar } \\
\hline \multicolumn{6}{|l|}{ Blue catfish } \\
\hline \multicolumn{6}{|l|}{ Bluegill } \\
\hline \multicolumn{6}{|c|}{ Brook silverside } \\
\hline \multicolumn{6}{|l|}{ Channel catfish } \\
\hline \multicolumn{6}{|l|}{ Common carp } \\
\hline \multicolumn{6}{|c|}{ Freshwater drum } \\
\hline \multicolumn{6}{|l|}{ Gizzard shad } \\
\hline \multicolumn{6}{|l|}{ Grass carp } \\
\hline \multicolumn{6}{|l|}{ Green sunfish } \\
\hline \multicolumn{6}{|c|}{ Inland silverside } \\
\hline \multicolumn{6}{|l|}{ Longnose gar } \\
\hline \multicolumn{6}{|l|}{ Sailfin molly } \\
\hline \multicolumn{6}{|c|}{ Smallmouth buffalo } \\
\hline \multicolumn{6}{|l|}{ Spotted gar } \\
\hline \multicolumn{6}{|l|}{ Threadfin shad } \\
\hline \multicolumn{6}{|l|}{ Warmouth } \\
\hline \multicolumn{6}{|l|}{ White crappie } \\
\hline \multicolumn{6}{|c|}{ Brackish water fish species } \\
\hline \multicolumn{6}{|c|}{ Atlantic croaker } \\
\hline \multicolumn{6}{|l|}{ Bay anchovy } \\
\hline \multicolumn{6}{|l|}{ Black drum } \\
\hline \multicolumn{6}{|c|}{ Spotted seatrout } \\
\hline Crevalle jack & & & & & \\
\hline Gafftopsail cat & & & & & \\
\hline Gulf menhade & & & & & \\
\hline Hardhead catfi & & & & & \\
\hline Ladyfish & & & & & \\
\hline Pinfish & & & & & \\
\hline Red drum & & & & & \\
\hline Sand seatrout & & & & & \\
\hline Sheepshead & & & & & \\
\hline Sheepshead $\mathrm{m}$ & & & & & \\
\hline Silver seatrout & & & & & \\
\hline Southern flour & & & & & \\
\hline Spot & & & & & \\
\hline Striped mullet & & & & & \\
\hline Tarpon & & & & & \\
\hline
\end{tabular}


Table 9. Fish species collected in Armand Bayou, Texas Gulf Coastal Plain, 2000-2001

[Modified from Hogan (2002, table 2)]

\begin{tabular}{|c|c|c|c|c|c|}
\hline & \multicolumn{5}{|c|}{ Sampling site } \\
\hline & ARM01 & ARM02 & ARM03 & HRSP01 & HRSP02 \\
\hline \multicolumn{6}{|c|}{ Freshwater fish species } \\
\hline \multicolumn{6}{|l|}{ Alligator gar } \\
\hline \multicolumn{6}{|l|}{ Black crappie } \\
\hline \multicolumn{6}{|l|}{ Blue catfish } \\
\hline \multicolumn{6}{|l|}{ Bluegill } \\
\hline \multicolumn{6}{|l|}{ Channel catfish } \\
\hline \multicolumn{6}{|l|}{ Gizzard shad } \\
\hline \multicolumn{6}{|l|}{ Green sunfish } \\
\hline \multicolumn{6}{|c|}{ Largemouth bass } \\
\hline \multicolumn{6}{|l|}{ Longear sunfish } \\
\hline \multicolumn{6}{|l|}{ Longnose gar } \\
\hline \multicolumn{6}{|l|}{ Sailfin molly } \\
\hline \multicolumn{6}{|c|}{ Smallmouth buffalo } \\
\hline \multicolumn{6}{|l|}{ Spotted gar } \\
\hline \multicolumn{6}{|c|}{ Western mosquitofish } \\
\hline \multicolumn{6}{|l|}{ White crappie } \\
\hline \multicolumn{6}{|l|}{ Yellow bullhead } \\
\hline \multicolumn{6}{|c|}{ Brackish water fish species } \\
\hline \multicolumn{6}{|c|}{ Atlantic croaker } \\
\hline \multicolumn{6}{|l|}{ Bay anchovy } \\
\hline \multicolumn{6}{|l|}{ Black drum } \\
\hline \multicolumn{6}{|c|}{ Gaftopsail catfish } \\
\hline \multicolumn{6}{|l|}{ Gulf menhaden } \\
\hline \multicolumn{6}{|c|}{ Hardhead catfish } \\
\hline \multicolumn{6}{|l|}{ Ladyfish } \\
\hline \multicolumn{6}{|l|}{ Lined sole } \\
\hline \multicolumn{6}{|l|}{ Pinfish } \\
\hline \multicolumn{6}{|l|}{ Red drum } \\
\hline Sand seatrout & & & & & \\
\hline Southern flounc & & & & & \\
\hline Spot & & & & & \\
\hline Striped mullet & & & & & \\
\hline
\end{tabular}


Table 10. Fish taxa and counts of individual fish collected in the San Bernard River, Texas Gulf Coastal Plain, 2000-2002

[Number of individuals per taxon shown for each site]

\begin{tabular}{|c|c|c|c|c|c|c|c|c|c|c|}
\hline \multirow{2}{*}{ Group } & \multirow{2}{*}{ Common name } & \multirow{2}{*}{ Family } & \multirow{2}{*}{ Scientific name } & \multicolumn{6}{|c|}{ Sampling site } & \multirow{2}{*}{ Tota } \\
\hline & & & & COUSH & WESTB & GUMTR & SANB01 & SANB02 & SANB03 & \\
\hline \multirow{3}{*}{ Gars } & & Lepisosteidae & & & & & & & & \\
\hline & Spotted gar & & Lepisosteus oculatus & 2 & 1 & 7 & 3 & 1 & 0 & 14 \\
\hline & Longnose gar & & Lepisosteus osseus & 0 & 0 & 0 & 0 & 0 & 1 & 1 \\
\hline \multirow[t]{2}{*}{ Herrings } & & Clupeidae & & & & & & & & \\
\hline & Gizzard shad & & Dorosoma cepedianum & 0 & 2 & 3 & 0 & 0 & 0 & 5 \\
\hline \multirow{2}{*}{ Livebearers } & & Poeciliidae & & & & & & & & \\
\hline & Mosquito fish & & Gambusia sp. & 12 & 40 & 94 & 10 & 2 & 0 & 158 \\
\hline \multirow{2}{*}{ Suckers } & Smallmouth huffalo & Catostomidae & Ictiobus hubalus & 0 & 3 & 1 & 2 & 1 & 0 & 7 \\
\hline & River carpsucker & & Carpiodes carpio & 0 & 13 & 0 & $\begin{array}{l}2 \\
0\end{array}$ & $\begin{array}{l}1 \\
0\end{array}$ & $\begin{array}{l}0 \\
0\end{array}$ & 13 \\
\hline \multirow{5}{*}{ Bullhead catfish } & & Ictaluridae & & & & & & & & \\
\hline & Tadpole madtom & & Noturus gyrinus & 1 & 1 & 0 & 0 & 0 & 0 & 2 \\
\hline & Channel catfish & & Ictalurus punctatus & 0 & 1 & 18 & 0 & 0 & 1 & 20 \\
\hline & Flathead catfish & & Pylodictis olivaris & 0 & 2 & 0 & 1 & 0 & 0 & 3 \\
\hline & Yellow bullhead & & Ameiurus natalis & 0 & 0 & 3 & 0 & 0 & 0 & 3 \\
\hline \multirow{10}{*}{ Sunfishes } & & Centrarchidae & & & & & & & & \\
\hline & White crappie & & Poxomis annularis & 0 & 0 & 0 & 7 & 0 & 0 & 7 \\
\hline & Green sunfish & & Lepomis cyanellus & 2 & 21 & 81 & 4 & 0 & 0 & 108 \\
\hline & Redear sunfish & & Lepomis microlophus & 5 & 0 & 0 & 0 & 0 & 0 & 5 \\
\hline & Longear sunfish & & Lepomis megalotis & 16 & 4 & 7 & 9 & 2 & 4 & 42 \\
\hline & Bluegill & & Lepomis macrochirus & 25 & 1 & 10 & 15 & 0 & 0 & 51 \\
\hline & Warmouth & & Lepomis gulosus & 5 & 4 & 4 & 17 & 2 & 0 & 32 \\
\hline & Largemouth bass & & Micropterus salmoides & 0 & 0 & 0 & 1 & 0 & 0 & 1 \\
\hline & Redeye bass & & Micropterus coosae & 0 & 2 & 0 & 0 & 0 & 0 & 2 \\
\hline & Spotted bass & & Micropterus punctulatus & 2 & 0 & 0 & 0 & 1 & 0 & 3 \\
\hline \multirow{2}{*}{ Pirate perches } & & Aphredoderidae & & & & & & & & \\
\hline & Pirate perch & & Aphredoderus sayanus & 5 & 4 & 1 & 0 & 0 & 0 & 10 \\
\hline \multirow{2}{*}{ Drums } & & Sciaenidae & & & & & & & & \\
\hline & Freshwater drum & & Aplodinotus grunniens & 0 & 0 & 5 & 0 & 0 & 1 & 6 \\
\hline \multirow[t]{4}{*}{ Perches } & & Percidae & & & & & & & & \\
\hline & Slough darter & & Etheostoma gracile & 0 & 1 & 2 & 0 & 0 & 0 & 3 \\
\hline & Bluntnose darter & & Etheostoma chlorosomum & 10 & 0 & 0 & 0 & 0 & 0 & 10 \\
\hline & Dusky darter & & Percina sciera & 0 & 0 & 0 & 0 & 1 & 0 & 1 \\
\hline \multirow[t]{2}{*}{ Killifishes } & & Cyprinodontidae & & & & & & & & \\
\hline & Blackstripe topminnow & & Fundulus notatus & 8 & 0 & 1 & 0 & 0 & 1 & 10 \\
\hline \multirow[t]{2}{*}{ Silversides } & & Atherinidae & & & & & & & & \\
\hline & Inland silverside & & Menidia beryllina & 0 & 0 & 1 & 0 & 0 & 0 & 1 \\
\hline \multirow[t]{6}{*}{ Minnows } & & Cyprinidae & & & & & & & & \\
\hline & Blacktail shiner & & Cyprinella venusta & 0 & 1 & 2 & 0 & 6 & 1 & 10 \\
\hline & Common carp & & Cyprinus carpio & 0 & 2 & 4 & 0 & 0 & 0 & 6 \\
\hline & Mimic shiner & & Notropis volucellus & 0 & 0 & 0 & 3 & 0 & 0 & 3 \\
\hline & Red shiner & & Cyprinella lutrensis & 0 & 3 & 9 & 0 & 6 & 4 & 22 \\
\hline & Bullhead minnow & & Pimephales vigilax & 7 & 0 & 3 & 11 & 6 & 1 & 28 \\
\hline \multirow[t]{2}{*}{ Pygmie sunfishes } & & Elassomatidae & & & & & & & & \\
\hline & Banded pygmy sunfish & & Elassoma zonatum & 0 & 0 & 0 & 2 & 1 & 0 & 3 \\
\hline Number of individuals & & & & 100 & 106 & 256 & 85 & 29 & 14 & 590 \\
\hline Number of taxa & & & & 13 & 18 & 19 & 13 & 11 & 8 & \\
\hline
\end{tabular}


¿ Table 11. Fish community data (metrics) for sites in Dickinson Bayou, Armand Bayou, and the San Bernard River, Texas Gulf Coastal Plain, 2000-2002

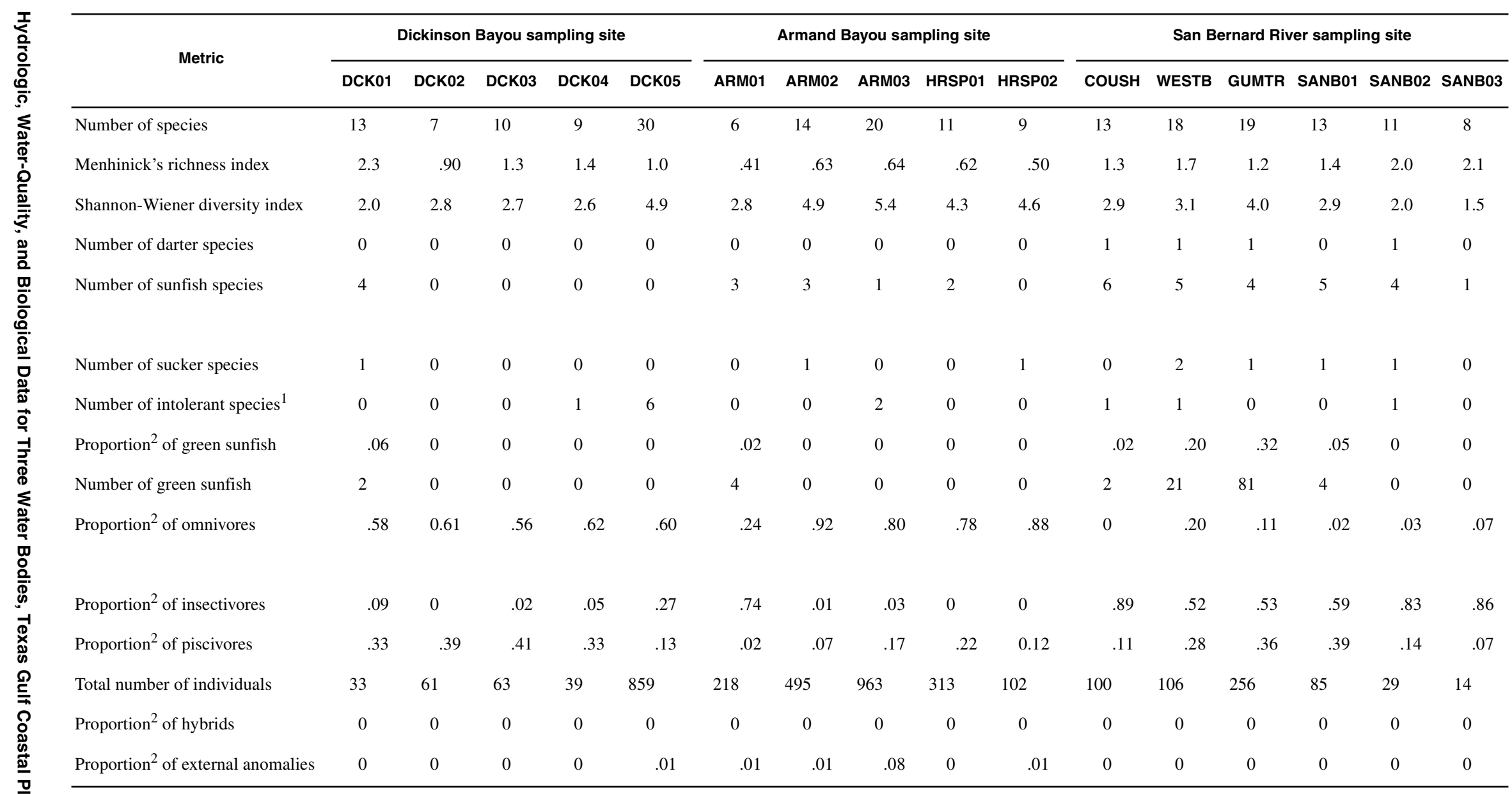

${ }^{1}$ Categorization of species intolerant to degraded water-quality conditions by Linam and Kleinsasser (1998).

${ }^{2}$ Proportion computed as ratio of number of individual fish in category to total number of fish collected at site. 
Table 12. Benthic macroinvertebrate taxa and counts of individual taxa collected in the San Bernard River, Texas Gulf Coastal Plain, 2000-2002

[Number of individuals per taxon shown for each site]

\begin{tabular}{|c|c|c|c|c|c|c|c|c|c|c|c|}
\hline \multirow{2}{*}{ Class } & \multirow{2}{*}{ Order } & \multirow{2}{*}{ Family } & \multirow{2}{*}{ Subfamily } & \multirow{2}{*}{$\begin{array}{c}\text { Genus or } \\
\text { scientific name }\end{array}$} & \multicolumn{7}{|c|}{ Sampling site } \\
\hline & & & & & COUSH & GUMTR & WESTB & SANB01 & SANB02 & SANB03 & Total \\
\hline \multirow[t]{4}{*}{ Arachnida } & Acari & & & Acari & 2 & 0 & 0 & 0 & 8 & 1 & 11 \\
\hline & & Hygrobatidae & & Hygrobatidae & 0 & 5 & 0 & 0 & 0 & 0 & 5 \\
\hline & & Unionicolidae & & Unionicolidae & 6 & 0 & 0 & 0 & 0 & 0 & 6 \\
\hline & & Sarcoptiformes & & Oribatei & 1 & 7 & 4 & 0 & 0 & 0 & 12 \\
\hline \multirow[t]{4}{*}{ Bivalvia } & & & & Bivalvia & 0 & 0 & 0 & 0 & 2 & 0 & 2 \\
\hline & Veneroidea & Sphaeriidae & & Eupera cubensis & 0 & 0 & 6 & 15 & 1 & 17 & 39 \\
\hline & & & & Pisidium sp. & 0 & 0 & 0 & 0 & 0 & 7 & 7 \\
\hline & & & & Sphaeriidae & 0 & 4 & 0 & 1 & 0 & 0 & 5 \\
\hline \multirow{6}{*}{$\begin{array}{l}\text { Crustacea } \\
\text { (Malacostraca) }\end{array}$} & Amphipoda & Talitridae & & Hyalella azteca & 0 & 0 & 0 & 13 & 0 & 1 & 14 \\
\hline & & & & Hyalella sp. & 17 & 0 & 24 & 0 & 0 & 0 & 41 \\
\hline & Decapoda & Astacidae & & Procambarus sp. & 2 & 2 & 0 & 0 & 0 & 0 & 4 \\
\hline & & Palaemonidae & & Palaemonetes kadiakensis & 13 & 4 & 11 & 20 & 12 & 15 & 75 \\
\hline & & & & Palaemonidae & 0 & 0 & 0 & 0 & 0 & 8 & 8 \\
\hline & Mysidacea & Mysidae & & Taphromysis louisianae & 0 & 0 & 0 & 9 & 0 & 0 & 9 \\
\hline \multirow[t]{8}{*}{ Gastropoda } & Basommatophora & Ancylidae & & Ancylidae & 2 & 0 & 0 & 6 & 1 & 1 & 10 \\
\hline & & & & Ferrissia sp. & 0 & 6 & 7 & 0 & 0 & 0 & 13 \\
\hline & & Lymnaeidae & & Lymnaeidae & 2 & 0 & 0 & 0 & 0 & 0 & 2 \\
\hline & & Planorbidae & & Planorbidae & 0 & 0 & 0 & 2 & 0 & 0 & 2 \\
\hline & & & & Menetus dilatatus & 0 & 21 & 12 & 0 & 0 & 0 & 33 \\
\hline & & Physidae & & Physella sp. & 0 & 0 & 0 & 0 & 1 & 0 & 1 \\
\hline & & & & Physidae & 6 & 0 & 1 & 0 & 0 & 0 & 7 \\
\hline & Neotaenioglossa & Hydrobiidae & & Hydrobiidae & 0 & 0 & 1 & 18 & 22 & 44 & 85 \\
\hline \multirow[t]{2}{*}{ Hirudinea } & Gnathobdellida & Hirudinidae & & Hirudinea & 0 & 0 & 0 & 4 & 1 & 2 & 7 \\
\hline & Rhynchobdellida & Glossiphoniidae & & Glossiphoniidae & 0 & 0 & 1 & 0 & 0 & 0 & 1 \\
\hline \multirow[t]{7}{*}{ Insecta } & Coleoptera & Dytiscidae & & Liodessus sp. & 0 & 0 & 0 & 0 & 0 & 1 & 1 \\
\hline & & Elmidae & & Dubiraphia sp. & 0 & 0 & 0 & 1 & 0 & 0 & 1 \\
\hline & & & & Dubiraphia bivittata & 0 & 0 & 2 & 0 & 0 & 0 & 2 \\
\hline & & & & Heterelmis sp. & 0 & 0 & 0 & 1 & 5 & 30 & 36 \\
\hline & & & & Stenelmis sp. & 1 & 0 & 19 & 1 & 2 & 0 & 23 \\
\hline & & Gyrinidae & & Dineutus sp. & 2 & 0 & 0 & 2 & 0 & 0 & 4 \\
\hline & & & & Gyretes sp. & 0 & 0 & 1 & 0 & 0 & 3 & 4 \\
\hline
\end{tabular}


o Table 12. Benthic macroinvertebrate taxa and counts of individual taxa collected in the San Bernard River, Texas Gulf Coastal Plain, 2000-2002Continued

\begin{tabular}{|c|c|c|c|c|c|c|c|c|c|c|c|}
\hline \multirow{2}{*}{ Class } & \multirow{2}{*}{ Order } & \multirow{2}{*}{ Family } & \multirow{2}{*}{ Subfamily } & \multirow{2}{*}{$\begin{array}{c}\text { Genus or } \\
\text { scientific name }\end{array}$} & \multicolumn{7}{|c|}{ Sampling site } \\
\hline & & & & & COUSH & GUMTR & WESTB & SANB01 & SANB02 & SANB03 & Total \\
\hline \multirow[t]{37}{*}{ Insecta—Cont. } & Coleoptera-Cont. & Haliplidae & & Peltodytes $\mathrm{sp}$. & 3 & 0 & 0 & 0 & 0 & 0 & 3 \\
\hline & & Hydraenidae & & Hydraena sp. & 1 & 0 & 0 & 0 & 0 & 0 & 1 \\
\hline & & Hydrophilidae & & Berosus sp. & 7 & 0 & 0 & 0 & 0 & 0 & 7 \\
\hline & & & & Hydrochus sp. & 0 & 0 & 0 & 0 & 0 & 1 & 1 \\
\hline & & Noteridae & & Hydrocanthus sp. & 0 & 0 & 1 & 0 & 0 & 0 & 1 \\
\hline & & Scirtidae & & Cyphon sp. & 0 & 2 & 7 & 3 & 1 & 1 & 14 \\
\hline & Diptera & Ceratopogonidae & & Atrichopogon sp. & 0 & 0 & 0 & 1 & 0 & 0 & 1 \\
\hline & & & & Bezzia/Palpomyia sp. & 4 & 0 & 0 & 0 & 0 & 0 & 4 \\
\hline & & & & Ceratopogonidae & 0 & 0 & 0 & 0 & 0 & 1 & 1 \\
\hline & & & Ceratopogoninae & Ceratopogoninae & 0 & 0 & 0 & 2 & 13 & 20 & 35 \\
\hline & & & & Labrundinia sp. & 25 & 9 & 30 & 67 & 1 & 0 & 132 \\
\hline & & & & Culicoides sp. & 3 & 0 & 0 & 0 & 0 & 0 & 3 \\
\hline & & & & Forcipomyia sp. & 0 & 1 & 0 & 0 & 0 & 0 & 1 \\
\hline & & & & Probezzia sp. & 2 & 0 & 0 & 0 & 0 & 0 & 2 \\
\hline & & Chaoboridae & & Chaoborus sp. & 1 & 0 & 0 & 0 & 0 & 0 & 1 \\
\hline & & Chironomidae & Chironominae & Chironomini & 0 & 1 & 0 & 0 & 0 & 2 & 3 \\
\hline & & & & Cladotanytarsus sp. & 10 & 1 & 0 & 0 & 8 & 1 & 20 \\
\hline & & & & Cryptochironomus sp. & 2 & 0 & 0 & 6 & 2 & 0 & 10 \\
\hline & & & & Cryptotendipes sp. & 1 & 0 & 0 & 1 & 0 & 0 & 2 \\
\hline & & & & Dicrotendipes sp. & 23 & 0 & 1 & 12 & 5 & 1 & 42 \\
\hline & & & & Endochironomus sp. & 76 & 0 & 0 & 0 & 0 & 0 & 76 \\
\hline & & & & Glyptotendipes sp. & 1 & 0 & 0 & 1 & 0 & 1 & 3 \\
\hline & & & & Harnischia sp. & 0 & 0 & 2 & 6 & 0 & 1 & 9 \\
\hline & & & & Parachironomus sp. & 0 & 1 & 0 & 13 & 4 & 5 & 23 \\
\hline & & & & Paracladopelma sp. & 0 & 0 & 0 & 0 & 0 & 1 & 1 \\
\hline & & & & Paralauterborniella nigrohalteris & 0 & 0 & 3 & 2 & 0 & 0 & 5 \\
\hline & & & & Polypedilum halterale grp. & 1 & 0 & 0 & 0 & 0 & 0 & 1 \\
\hline & & & & Polypedilum illinoense gr & 39 & 64 & 9 & 0 & 0 & 0 & 112 \\
\hline & & & & Polypedilum scalaenum gr. & 0 & 3 & 8 & 2 & 5 & 33 & 51 \\
\hline & & & & Polypedilum sp. & 0 & 0 & 0 & 24 & 1 & 2 & 27 \\
\hline & & & & Pseudochironomus sp. & 5 & 0 & 0 & 0 & 0 & 7 & 12 \\
\hline & & & & Rheotanytarsus sp. & 7 & 59 & 0 & 1 & 0 & 0 & 67 \\
\hline & & & & Stenochironomus sp. & 1 & 6 & 3 & 0 & 3 & 8 & 21 \\
\hline & & & & Tanytarsus sp. & 5 & 26 & 13 & 7 & 7 & 14 & 72 \\
\hline & & & & Tribelos fuscicorne & 0 & 0 & 0 & 4 & 0 & 17 & 21 \\
\hline & & & & Tribelos sp. & 2 & 0 & 4 & 0 & 0 & 0 & 6 \\
\hline & & & Orthocladiinae & Corynoneura sp. & 0 & 1 & 3 & 0 & 1 & 4 & 9 \\
\hline
\end{tabular}


Table 12. Benthic macroinvertebrate taxa and counts of individual taxa collected in the San Bernard River, Texas Gulf Coastal Plain, 2000-2002Continued

\begin{tabular}{|c|c|c|c|c|c|c|c|c|c|c|c|}
\hline \multirow{2}{*}{ Class } & \multirow{2}{*}{ Order } & \multirow{2}{*}{ Family } & \multirow{2}{*}{ Subfamily } & \multirow{2}{*}{$\begin{array}{c}\text { Genus or } \\
\text { scientific name }\end{array}$} & \multicolumn{7}{|c|}{ Sampling site } \\
\hline & & & & & COUSH & GUMTR & WESTB & SANB01 & SANB02 & SANB03 & Total \\
\hline \multirow[t]{37}{*}{ Insecta—Cont. } & Diptera-Cont. & Chironomidae & Orthocladiinae & Cricotopus bicinctus gr. & 0 & 0 & 0 & 0 & 1 & 0 & 1 \\
\hline & & & & Cricotopus sp. & 0 & 0 & 0 & 0 & 2 & 0 & 2 \\
\hline & & & & Nanocladius distinctus & 0 & 0 & 0 & 0 & 1 & 0 & 1 \\
\hline & & & & Nanocladius sp. & 26 & 10 & 2 & 29 & 0 & 2 & 69 \\
\hline & & & & Rheocricotopus robacki & 0 & 0 & 0 & 1 & 10 & 0 & 11 \\
\hline & & & & Rheocricotopus sp. & 0 & 1 & 0 & 0 & 0 & 0 & 1 \\
\hline & & & & Thienemanniella sp. & 0 & 1 & 0 & 3 & 3 & 0 & 7 \\
\hline & & & Tanypodinae & Ablabesmyia sp. & 22 & 12 & 14 & 74 & 5 & 26 & 153 \\
\hline & & & & Clinotanypus sp. & 0 & 0 & 0 & 0 & 0 & 2 & 2 \\
\hline & & & & Larsia sp. & 1 & 0 & 0 & 0 & 0 & 0 & 1 \\
\hline & & & & Pentaneura sp. & 0 & 0 & 0 & 2 & 17 & 0 & 19 \\
\hline & & & & Procladius sp. & 1 & 0 & 2 & 0 & 0 & 0 & 3 \\
\hline & & & & Thienemannimyia gr. sp. & 1 & 0 & 1 & 0 & 0 & 2 & 4 \\
\hline & & Culicidae & & Anopheles sp. & 0 & 0 & 1 & 0 & 0 & 0 & 1 \\
\hline & & Diptera & & Diptera & 0 & 0 & 0 & 2 & 0 & 0 & 2 \\
\hline & & Phoridae & & Phoridae & 0 & 0 & 0 & 3 & 0 & 0 & 3 \\
\hline & & Sciomyzidae & & Sciomyzidae & 0 & 0 & 0 & 4 & 0 & 0 & 4 \\
\hline & & Simuliidae & & Simuliidae & 0 & 0 & 0 & 0 & 1 & 0 & 1 \\
\hline & & Tabanidae & & Tabanidae & 0 & 0 & 0 & 1 & 0 & 0 & 1 \\
\hline & Ephemeroptera & Baetidae & & Baetidae & 0 & 0 & 0 & 0 & 1 & 1 & 2 \\
\hline & & & & Baetis sp. & 0 & 2 & 0 & 0 & 1 & 0 & 3 \\
\hline & & & & Centroptilum sp. & 3 & 0 & 0 & 0 & 0 & 0 & 3 \\
\hline & & & & Fallceon quilleri & 0 & 37 & 8 & 0 & 47 & 1 & 93 \\
\hline & & & & Procloeon sp. & 0 & 0 & 0 & 2 & 0 & 1 & 3 \\
\hline & & & & Pseudocloeon sp. & 0 & 0 & 0 & 6 & 0 & 0 & 6 \\
\hline & & Caenidae & & Caenis diminuta & 16 & 0 & 0 & 0 & 0 & 0 & 16 \\
\hline & & & & Caenis hilaris & 19 & 0 & 0 & 0 & 0 & 0 & 19 \\
\hline & & & & Caenis latipennis & 0 & 0 & 38 & 9 & 0 & 0 & 47 \\
\hline & & & & Caenis punctata & 30 & 0 & 0 & 0 & 0 & 0 & 30 \\
\hline & & & & Caenis sp. & 0 & 1 & 0 & 5 & 24 & 1 & 31 \\
\hline & & Heptageniidae & & Heptageniidae & 0 & 3 & 0 & 0 & 3 & 0 & 6 \\
\hline & & & & Stenacron interpunctatum & 0 & 0 & 30 & 11 & 1 & 0 & 42 \\
\hline & & & & Stenacron sp. & 0 & 0 & 0 & 0 & 0 & 1 & 1 \\
\hline & & Isonychiidae & & Isonychia sp. & 0 & 0 & 0 & 0 & 9 & 1 & 10 \\
\hline & & Leptophlebiidae & & Leptophlebiidae & 0 & 0 & 0 & 1 & 7 & 1 & 9 \\
\hline & & Tricorythidae & & Tricorythodes sp. & 0 & 0 & 0 & 0 & 132 & 13 & 145 \\
\hline & Hemiptera & Corixidae & & Corixidae & 5 & 0 & 2 & 0 & 0 & 0 & 7 \\
\hline
\end{tabular}


ง Table 12. Benthic macroinvertebrate taxa and counts of individual taxa collected in the San Bernard River, Texas Gulf Coastal Plain, 2000-2002Continued

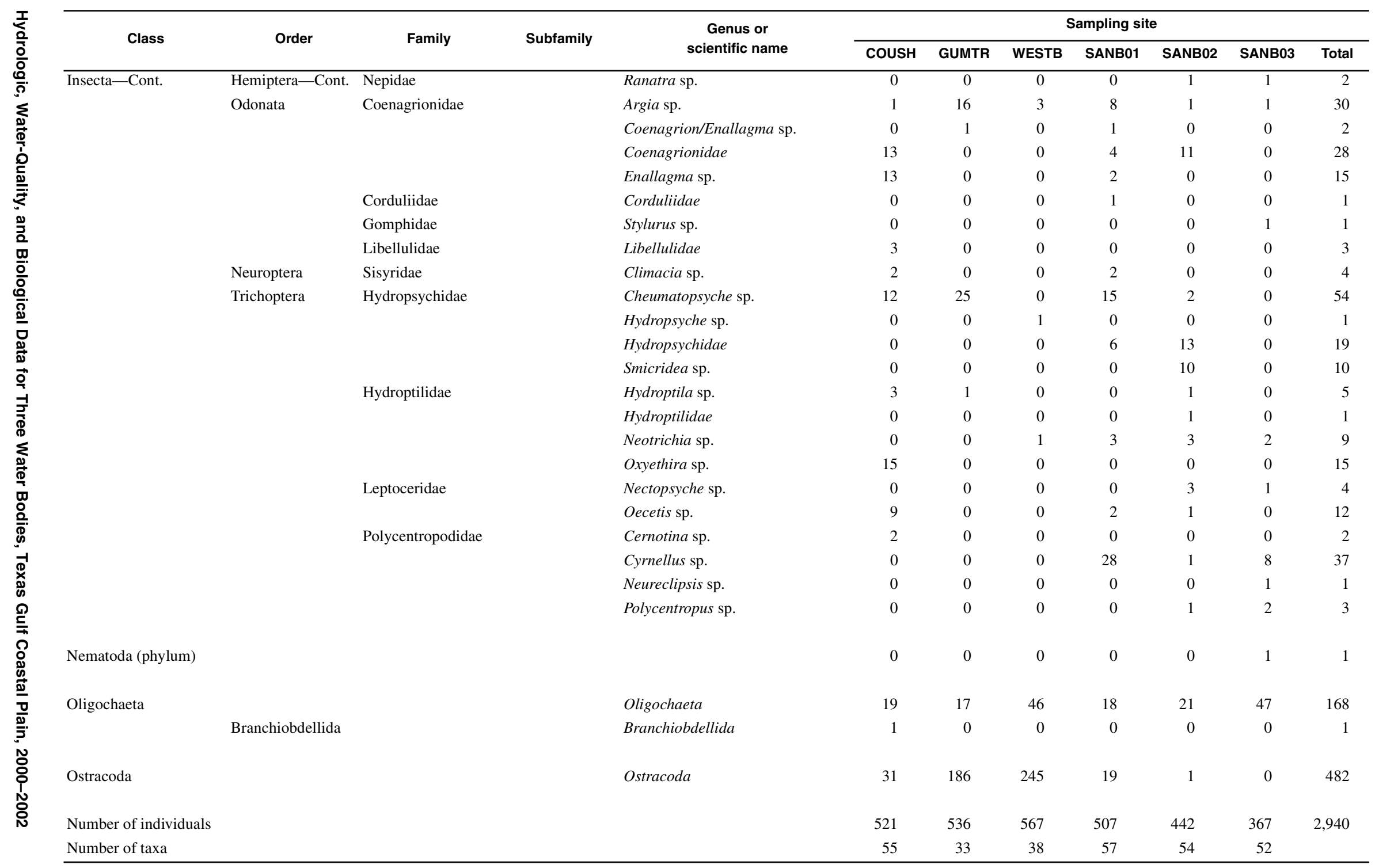


Table 13. Benthic macroinvertebrate data (metrics) for sites in Dickinson Bayou, Armand Bayou, and the San Bernard River, Texas Gulf Coastal Plain, 2000-2001

[EPT, Ephemeroptera Plecoptera Trichoptera]

\begin{tabular}{|c|c|c|c|c|c|c|c|c|c|c|c|c|c|c|c|c|}
\hline \multirow{2}{*}{ Metric } & \multicolumn{5}{|c|}{ Dickinson Bayou sampling site } & \multicolumn{5}{|c|}{ Armand Bayou sampling site } & \multicolumn{6}{|c|}{ San Bernard River sampling site } \\
\hline & DCK01 & DCK02 & DCK03 & DCK04 & DCK05 & ARM01 & ARM02 & ARM03 & HRSP01 & HRSP02 & COUSH & WESTB & GUMTR & SANB01 & SANB02 & SANB03 \\
\hline Number of taxa & 35 & 4 & 25 & 15 & 22 & 34 & 25 & 20 & 26 & 24 & 53 & 38 & 31 & 57 & 54 & 52 \\
\hline EPT taxa richness & 11 & 1 & 1 & 1 & 4 & 2 & 3 & 0 & 4 & 1 & 9 & 5 & 6 & 11 & 19 & 13 \\
\hline Percent EPT taxa & 4.4 & .48 & .10 & .22 & .75 & 2.8 & 1.6 & 0 & .70 & .98 & 21 & 14 & 13 & 17 & 59 & 9.3 \\
\hline Percent Chironomidae & 8.0 & 56 & 36 & 21 & 7.8 & 84 & 52 & 26 & 32 & 35 & 49 & 17 & 37 & 50 & 17 & 35 \\
\hline Percent Ephemeroptera & 4.3 & .48 & .10 & .22 & .55 & 2.8 & 1.6 & 0 & .56 & .98 & 13 & 13 & 8 & 6.7 & 51 & 5.4 \\
\hline Percent Oligochaeta & 23 & 16 & .50 & 44 & 6.7 & .47 & 1.6 & 28 & 24 & 41 & 3.8 & 8.1 & 3.2 & 3.6 & 4.7 & 13 \\
\hline Percent Plecoptera & 0 & 0 & 0 & 0 & 0 & 0 & 0 & 0 & 0 & 0 & 0 & 0 & 0 & 0 & 0 & 0 \\
\hline Percent Trichoptera & .16 & 0 & 0 & 0 & .20 & 0 & 0 & 0 & .13 & 0 & 8.1 & .35 & 4.9 & 11 & 8.1 & 3.8 \\
\hline Percent filterers & 19 & 0 & 3.1 & 13 & 22 & 3.7 & 2.1 & 19 & 1.3 & 2.7 & 4.7 & 3.5 & 22 & 11 & 5.9 & 8.2 \\
\hline Percent gatherers & 58 & 67 & 58 & 31 & 5.4 & 85 & 28 & 16 & 58 & 50 & 28 & 60 & 50 & 26 & 63 & 32 \\
\hline Percent predators & 10 & 33 & 2.2 & 31 & 19 & 2.8 & 34 & 13 & 22 & 12 & 19 & 9.7 & 9.4 & 34 & 14 & 16 \\
\hline Percent scrapers & 4.3 & 0 & 9.0 & 1.6 & 2.8 & 6.6 & 0 & .35 & .58 & .78 & 2.2 & 10 & 1.9 & 7.5 & 6.8 & 12 \\
\hline Percent shredders & 25 & 56 & 20 & 4.9 & 3.9 & .54 & 30 & 13 & 13 & 7.7 & 26 & 3.4 & 13 & 5.1 & 2.7 & 9.8 \\
\hline Number of filterer taxa & 8 & 0 & 4 & 2 & 4 & 3 & 4 & 2 & 3 & 4 & 3 & 3 & 4 & 6 & 6 & 4 \\
\hline Number of gatherer taxa & 16 & 2 & 7 & 5 & 3 & 9 & 11 & 5 & 12 & 7 & 13 & 12 & 13 & 17 & 17 & 22 \\
\hline Number of predator taxa & 10 & 2 & 3 & 1 & 5 & 16 & 7 & 6 & 8 & 9 & 16 & 7 & 6 & 12 & 10 & 10 \\
\hline Number of scraper taxa & 2 & 0 & 1 & 1 & 1 & 5 & 0 & 1 & 2 & 2 & 4 & 5 & 3 & 5 & 6 & 2 \\
\hline Number of shredder taxa & 4 & 1 & 2 & 1 & 3 & 3 & 2 & 2 & 3 & 3 & 5 & 3 & 2 & 2 & 5 & 3 \\
\hline Shannon-Wiener diversity index & 1.2 & .50 & .80 & .98 & 1.0 & .40 & 1.0 & .88 & .93 & .87 & 1.4 & 1.0 & 1.0 & 1.4 & 1.3 & 1.4 \\
\hline Hilsenhoff's biotic index & 4.4 & 2.4 & 2.3 & 2.0 & .42 & 5.1 & 4.5 & 1.2 & 2.7 & 1.0 & 5.7 & 6.3 & 5.9 & 6.2 & 5.7 & 5.7 \\
\hline Margalef's richness index & 5.1 & 1.4 & 3.2 & 3.4 & 3.3 & 4.1 & 4.1 & 3.0 & 4.0 & 3.1 & 5.8 & 4.6 & 3.2 & 6.8 & 6.9 & 8.6 \\
\hline Pielou's evenness index & .78 & .83 & .57 & .70 & .74 & .25 & .55 & .56 & .50 & .50 & .83 & .65 & .69 & .82 & .74 & .80 \\
\hline Simpson's heterogeneity index & .90 & .62 & .75 & .85 & .88 & .32 & .83 & .80 & .78 & .81 & .95 & .79 & .84 & .94 & .88 & .94 \\
\hline
\end{tabular}


Table 14. Physical-habitat data for stream reaches at sites in the San Bernard River, Texas Gulf Coastal Plain, 2000-2001

[ft, feet; --, not available]

\begin{tabular}{|c|c|c|c|c|c|c|}
\hline \multirow{2}{*}{ Datum } & \multicolumn{6}{|c|}{ Sampling site } \\
\hline & COUSH & WESTB & GUMTR & SANB01 & SANB02 & SANB03 \\
\hline Linear reach length $(\mathrm{ft})$ & 451 & 222 & 283 & 338 & 375 & 361 \\
\hline Curvilinear reach length $(\mathrm{ft})$ & 488 & 251 & 295 & 422 & 400 & 376 \\
\hline Sinuosity & 1.08 & 1.13 & 1.04 & 1.25 & 1.07 & 1.04 \\
\hline Reach slope & .0252 & .0081 & .0001 & .0004 & .0007 & .0009 \\
\hline Number of snags & -- & -- & -- & 8 & 3 & 10 \\
\hline Number of other obstructions & -- & -- & -- & 2 & 3 & 4 \\
\hline Number of stumps & -- & -- & -- & 0 & 1 & 0 \\
\hline Number of undercut banks & -- & -- & -- & 0 & 0 & 0 \\
\hline Number of bars & -- & -- & -- & 0 & 0 & 0 \\
\hline Mean right bank slope & .36 & .27 & .24 & .20 & .17 & .21 \\
\hline Mean left bank slope & .14 & .36 & .27 & .22 & .20 & .32 \\
\hline Mean bank slope & .25 & .32 & .26 & .21 & .19 & .27 \\
\hline Mean channel width (ft) & 65.9 & 68.0 & 44.5 & 73.4 & 107 & 108 \\
\hline Mean right bank height (ft) & 9.35 & 11.5 & 8.27 & 6.56 & 15 & 18.6 \\
\hline Mean left bank height (ft) & 5.99 & 8.50 & 7.29 & 6.88 & 14 & 19.9 \\
\hline Mean bank height/channel width ratio & .32 & .47 & .48 & .10 & .14 & .18 \\
\hline Mean wetted channel width (ft) & 27.0 & 22.2 & 17.0 & 29.8 & 51.1 & 51.9 \\
\hline Mean depth (ft) & 3.16 & 2.68 & 1.38 & 3.18 & 4.42 & 4.91 \\
\hline
\end{tabular}

